\title{
Correlation, Sedimentology, Structural Setting, Chemical Composition, and Provenance of Selected Formations in Mesoproterozoic Lemhi Group, Central Idaho
}

U.S. Geological Survey Professional Paper 1668

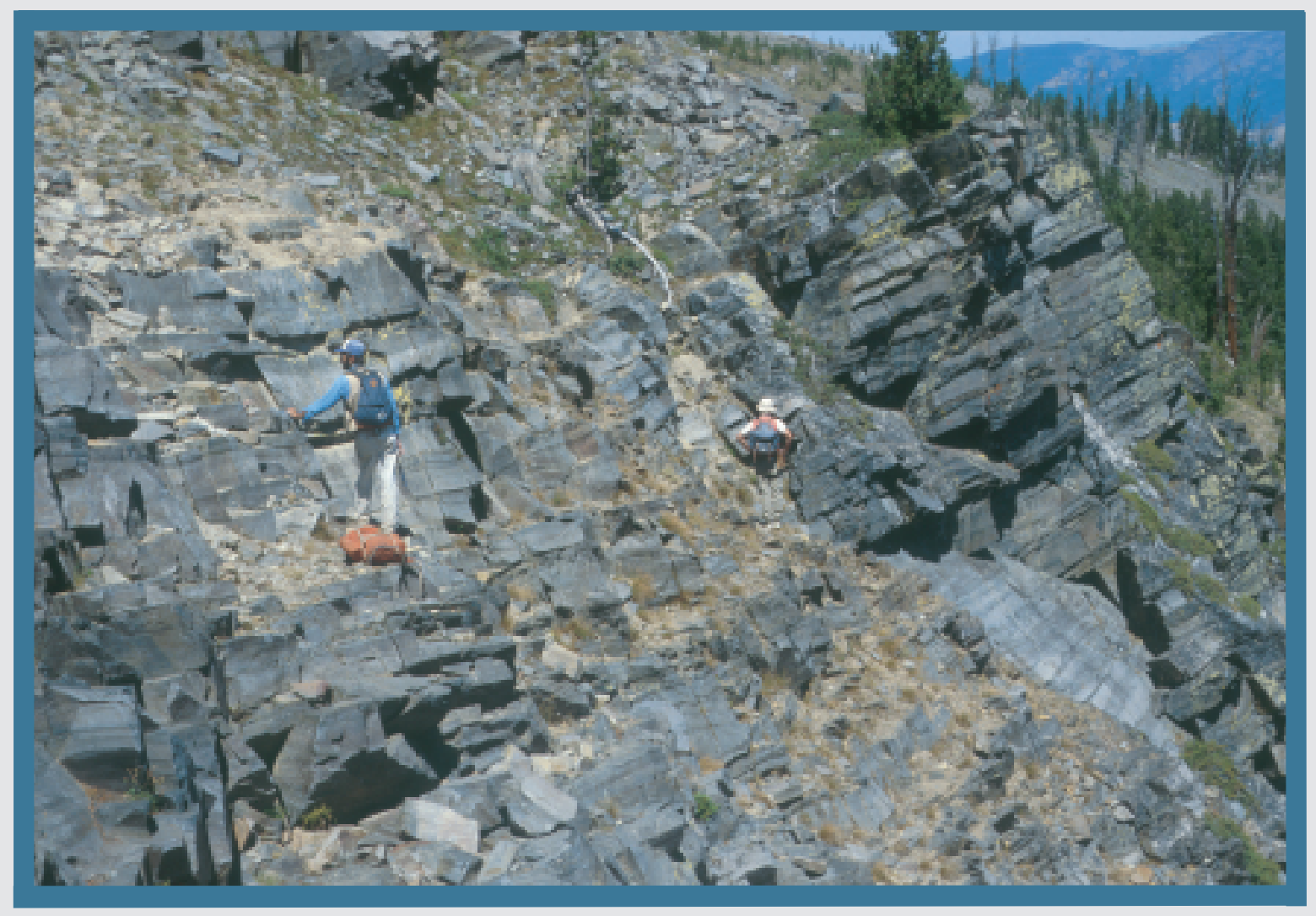

U.S. Department of the Interior U.S. Geological Survey 
Cover. Hummocky crossbedded metasandstone, east side of Lake Mountain, east-central part of Salmon River Mountains. 


\section{Correlation, Sedimentology, Structural Setting, Chemical Composition, and Provenance of Selected Formations in Mesoproterozoic Lemhi Group, Central Idaho}

By Russell G. Tysdal, David A. Lindsey, and Joseph E. Taggart, Jr.

A. Correlation, Sedimentology, and Structural Setting, Upper Strata of Mesoproterozoic Apple Creek Formation and Lower Strata of Gunsight Formation, Lemhi Range to Salmon River Mountains, East-Central Idaho ByRussell G. Tysdal

B. Chemical Composition and Provenance of the Mesoproterozoic Big Creek, Apple Creek, and Gunsight Formations, Lemhi Group, Central Idaho By David A. Lindsey, Russell G. Tysdal, and Joseph E. Taggart, Jr.

U.S. Geological Survey Professional Paper 1668-A-B

Chapters $A$ and $B$ are issued as a single volume and are not available separately 


\section{U.S. Department of the Interior \\ Gale A. Norton, Secretary}

\section{U.S. Geological Survey Charles G. Groat, Director}

Reston, Virginia, First Printing 2003

For sale by U.S. Geological Survey, Information Services

Box 25286, Federal Center

Denver, CO 80225

Published in the Central Region, Denver, Colorado

Manuscript approved for publication August 28, 2002

Graphics by authors

Photocomposition by Norma J. Maes

Edited by L.M. Carter

Any use of trade, product, or firm names in this publication

is for descriptive purposes only and

does not imply endorsement by the U.S. Government

Library of Congress Cataloging-in-Publication Data

Tysdal, Russell G.

Correlation, sedimentology, structural setting, chemical composition, and provenance of selected formations in Mesoproterozoic Lemhi Group, central Idaho / by R.G. Tysdal, David A. Lindsey, and Joseph E. Taggart, Jr.

p. cm.-(U.S. Geological Survey professional paper ; 1668 A-B)

Includes bibliographical references.

1. Geology, Stratigraphic-Proterozoic. 2. Formations (Geology)-Idaho. 3. Lemhi Group (Idaho). I. Lindsey, David A. II. Taggart, Joseph E., Jr. III. Title. IV. Series.

QE653.5 .T964 2003

$551.7^{\prime} 15^{\prime} 09796-\mathrm{dc} 21$

2002190815 
Correlation, Sedimentology, and Structural Setting, Upper Strata of Mesoproterozoic Apple Creek Formation and Lower Strata of Gunsight Formation, Lemhi Range to Salmon River Mountains, East-Central Idaho

ByRussell G. Tysdal

Chapter A of

Correlation, Sedimentology, Structural Setting, Chemical Composition, and Provenance of Selected Formations in Mesoproterozoic Lemhi Group, Central Idaho

By Russell G. Tysdal, David A. Lindsey, and Joseph E. Taggart, Jr.

U.S. Geological Survey Professional Paper 1668-A

U.S. Department of the Interior

U.S. Geological Survey 


\section{Contents}

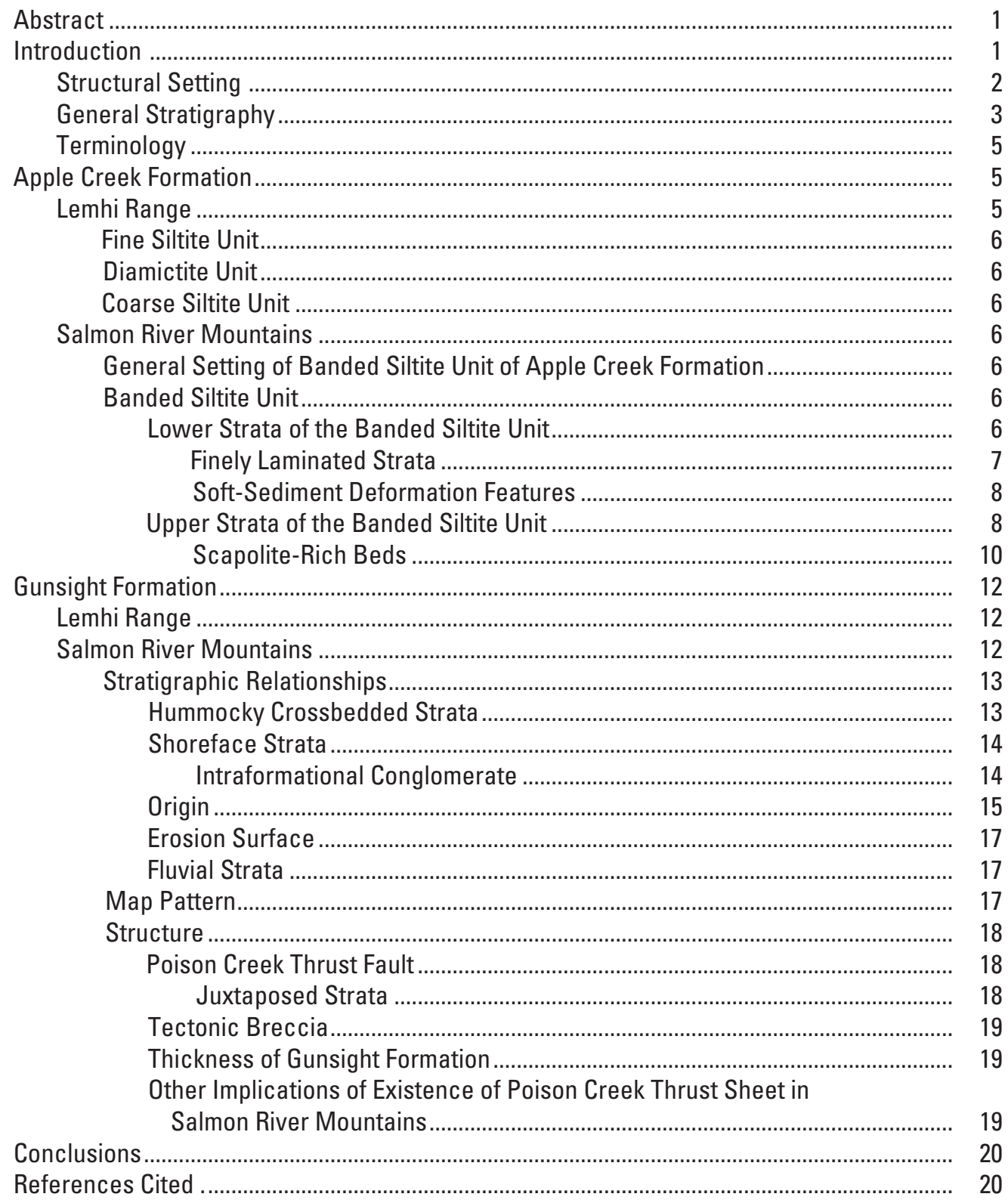

\section{Figures}

1. Index map of east-central Idaho ……………………............................................... 2

2. Map showing geology of central part of Salmon River Mountains and western part of Lemhi Range.

3. Map showing geology of Lake Mountain-Deep Creek area, and location of

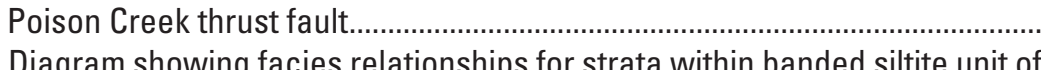

4. Diagram showing facies relationships for strata within banded siltite unit of Apple Creek and Gunsight Formations in Salmon River Mountains 
5-14. Photographs showing:

5. Finely laminated strata in banded siltite unit of Apple Creek Formation in

Salmon River Mountains.

6. Dikelets in banded siltite unit of Apple Creek Formation ...

7. Typical outcrop of upper strata of banded siltite unit of Apple Creek Formation, showing interlayered beds of light-gray metasandstone and dark-gray siltite...... 10

8. Detailed view of upper strata of banded siltite unit of Apple Creek Formation ...... 11

9. Light-gray metasandstone bed cut by dark-gray siltite during soft-sediment deformation

10. Dikelets associated with light-gray metasandstone bed cut by dark-gray siltite during soft-sediment deformation

11. Hummocky crossbeds at Lake Mountain in Salmon River Mountains 14

12. Slump structure overlain by non-slumped hummocky crossbedded metasandstone and other metasandstone beds

13. Light-gray hummocky crossbedded metasandstone bed deposited on dark-gray siltite, interpreted as water-saturated at time of deposition.

14. Flow-rolls in siltite, interpreted as channel deposit associated with the hummocky crossbedded metasandstone unit

\section{Table}

1. Correlation diagram for Mesoproterozoic formations in hangingwall and footwall of Poison Creek thrust sheet in western part of Lemhi Range and eastern part of Salmon River Mountains. 


\title{
Correlation, Sedimentology, and Structural Setting, Upper Strata of Mesoproterozoic Apple Creek Formation and Lower Strata of Gunsight Formation, Lemhi Range to Salmon River Mountains, East-Central Idaho
}

\author{
ByRussell G. Tysdal
}

\section{Abstract}

A unit of the Mesoproterozoic Apple Creek Formation of the Lemhi Range previously was correlated with part of the lower subunit of the Mesoproterozoic Yellowjacket Formation in the Salmon River Mountains. Strata currently assigned to the middle subunit of the Yellowjacket Formation lie conformably above the Apple Creek unit in the Salmon River Mountains, and are here renamed the banded siltite unit and reassigned to the Apple Creek Formation. Almost all of the banded siltite unit is preserved within the Salmon River Mountains, where it grades upward into clastic rocks that currently are assigned to the upper subunit of the Yellowjacket Formation and that here are reassigned to the Gunsight Formation.

The banded siltite unit of the Apple Creek Formation is composed of a turbidite sequence, as recognized by previous workers. Uppermost strata of the unit were reworked by currents, possibly storm generated, and adjusted to a high water content by developing abundant soft-sediment deformation features. Basal strata of the overlying Gunsight Formation in the Salmon River Mountains display abundant hummocky crossbeds, storm-generated features deposited below fair-weather wave base, that are conformable above the storm-reworked deposits. The hummocky crossbedded strata grade upward into marine shoreface strata deposited above fair-weather wave base, which in turn are succeeded by fluvial strata. Hummocky and shoreface strata are absent from the Gunsight Formation in the Lemhi Range. The major thickness of the Gunsight Formation in both the Salmon River Mountains and the Lemhi Range is composed of fluvial rocks, transitional in the upper part into marine rocks of the Swauger Formation. The fluvial strata are mainly characterized by stacked sheets of metasandstone and coarse siltite; they are interpreted as deposits of braided rivers.

The Poison Creek thrust fault of the Lemhi Range extends northwestward through the study area in the east-central part of the Salmon River Mountains. The Apple Creek and Gunsight Formations on the southwest side of the thrust fault were transported to the northeast as part of the Poison Creek thrust sheet. A segment of the thrust fault within the Gunsight Formation in the Salmon River Mountains subsequently underwent normal displacement. Along this segment, lower Gunsight strata on the

${ }^{1}$ The terms Middle and Late Proterozoic, respectively, were used for these eras in previous publications by the author. The present usage follows that of the International Union of Geological Sciences (IUGS) subcommittee on Precambrian stratigraphy (Plumb, 1991). southwest were juxtaposed against upper Gunsight and Swauger strata on the northeast.

\section{Introduction}

The general goal of this report is to correlate selected stratigraphic units in the Salmon River Mountains with those established in the Lemhi Range (fig. 1). New stratigraphic correlations and reconciliation of conflicting correlations and nomenclature for the Mesoproterozoic ${ }^{1}$ Yellowjacket Formation and most units of the Mesoproterozoic Apple Creek Formation in central Idaho (fig. 1) were presented in Tysdal (2000a). The purpose of the present report is (1) to demonstrate that a unit previously assigned to the Yellowjacket Formation is actually the uppermost unit of the Apple Creek Formation, (2) to show that strata previously assigned to the upper subunit of the Yellowjacket Formation or to other formations or units clearly correlate with the Gunsight Formation, and (3) to reconcile the differing nomenclature presently used for these formations in the Salmon River Mountains. The effort focused on working out the geology of selected local areas in the east-central part of the Salmon River Mountains critical to determining the correlations. Interpretations of depositional environments are employed in determining stratigraphic relationships for the Apple Creek

Formation. The interpetations generally differ from those presented in Winston and others (1999), although their work is of a reconnaissance nature.

This report builds on earlier work of Connor and Evans (1986), Connor (1990), Sobel (1982), and Tysdal (2000a). The latter report correlated rocks of the Lemhi Range with rocks in the Salmon River Mountains of central Idaho (fig. 1) and reconciled conflicting usage of the Yellowjacket Formation name and rocks assigned to it. The present report is mainly concerned with the upper part of the Apple Creek Formation and with the directly overlying Gunsight Formation. The stratigraphic chart (table 1) shows the correlation of rock units. The chart is simplified from that in Tysdal (2000a), which predates the scheme of Winston and others (1999), even though its actual publication date followed that of the latter report.

The present report is an outgrowth of studies related to regional stratigraphic correlation designed to determine the stratigraphic setting and limits of stratabound deposits of cobaltcopper-gold in the Blackbird mining district, in the vicinity of the townsite of Cobalt (fig. 1). The original work subsequently 


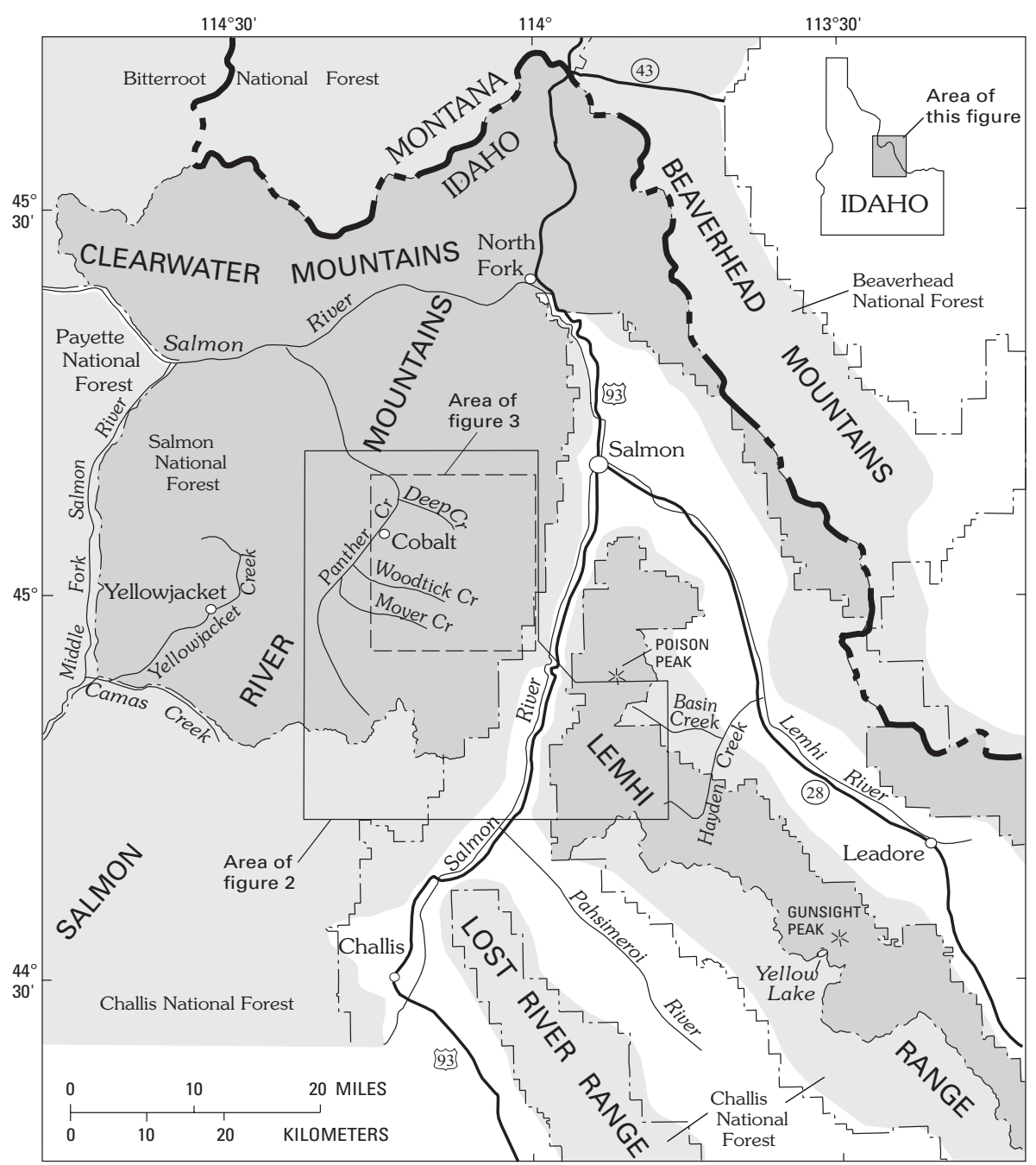

Figure 1. East-central Idaho and adjacent part of southwestern Montana, showing geographic features and areas of figures 2 and 3 . Light shade, mountains; dark shade, areas of Salmon National Forest within mountains. Dash-dot lines, boundaries of national forests.

was augmented to provide a stratigraphic basis for mineral resource and geoenvironmental studies of the Salmon National Forest, and eventually for Federal and other lands in central and northern Idaho and western Montana. Forest areas in the study region are shown in figure 1.

\section{Structural Setting}

The general structural setting of the study area is briefly described to place the Apple Creek and Gunsight Formations into a broad context that shows the structural continuity of the formations from the Lemhi Range to the Salmon River Mountains. This general structural context aids the interpretation of the correlations of strata of the two ranges.

East-central Idaho lies in the hinterland of the Cordilleran thrust belt. The region consists of a series of thrust sheets that were transported to the northeast, probably during the Late Cretaceous (Tysdal, 2002). Differing lithofacies of the Mesoproterozoic rocks discussed in this report have been telescopedplaced closer to one another than when originally deposited-by the thrust faulting. The Poison Creek thrust fault, a major fault of the region, trends northwest across the western part of the
Lemhi Range and into the eastern part of the Salmon River Mountains (fig. 2). Mapping of the fault and its related features in the Salmon River Mountains (figs. 2, 3) proved critical to unraveling the juxtaposed lithofacies discussed in this report. The hangingwall of this thrust fault is the Poison Creek thrust sheet and the footwall is the McDevitt Creek thrust sheet (fig. 2, inset map) (Tysdal, 2002). The Mesoproterozoic Apple Creek Formation areally is the most extensively exposed formation of the hangingwall Poison Creek thrust sheet in the map area (fig. 2). The Mesoproterozoic Gunsight Formation is the most extensively exposed formation of the footwall McDevitt Creek thrust sheet. The Gunsight Formation is conformably overlain by the Swauger Formation. Lower Paleozoic formations, preserved only in small areas of the footwall McDevitt Creek thrust sheet in the Lemhi Range, lie unconformably on the Mesoproterozoic strata. These formations are composed of limestone, dolostone, and quartzite.

Normal faults formed during Cenozoic and (?)Cretaceous extension, subsequent to the thrust faulting. The Lem Peak normal fault (fig. 2, inset map) trends west to northwest across the Lemhi Range and into the eastern part of the Salmon River Mountains. It downdropped rocks directly southwest of the Poison Creek thrust sheet. Stratigraphic units southwest of the 


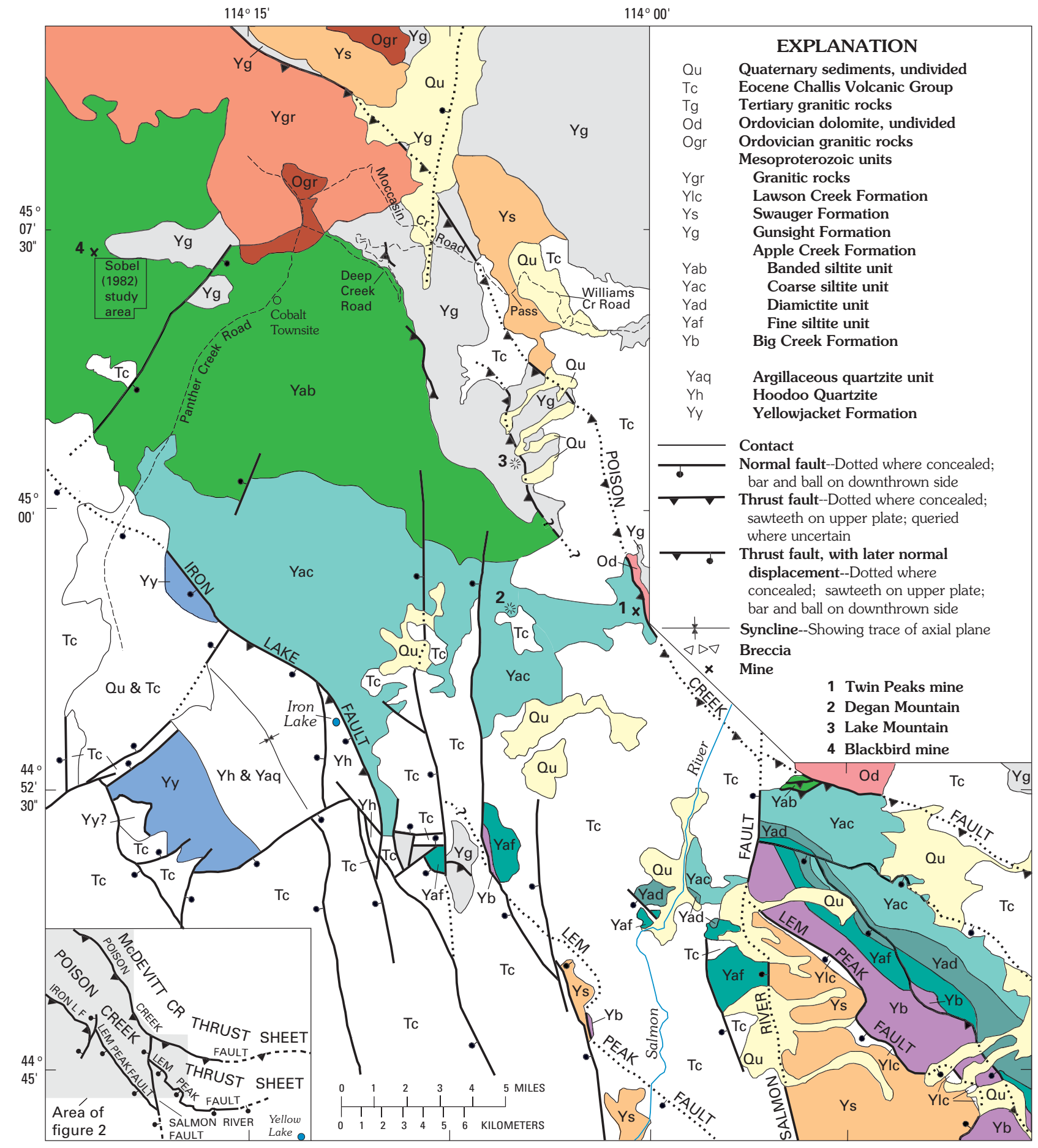

Figure 2. Geology of central part of Salmon River Mountains and adjacent western part of Lemhi Range. Lemhi Range lies east of Salmon River fault shown in inset map, lower left corner of figure.

Lem Peak fault differ from those on the Poison Creek sheet, as discussed in the next section.

\section{General Stratigraphy}

The Apple Creek Formation of the Lemhi Range was divided into four units by Tysdal (2000b). Three units lie on the Poison Creek thrust sheet (fig. 2, inset map) and, in ascending order, are the fine siltite unit, the diamictite unit, and the coarse siltite unit (table 1). The fourth unit, named the Yellow Lake unit, lies within another thrust sheet (fig. 2, inset map), now downdropped southwest of the Lem Peak normal fault, and is not considered in any detail in this report. The Yellow Lake unit is thinner than any of the other units and of somewhat different character. It is considered to be of a different facies and to be the time equivalent of part or all of the other four lithofacies of this report (table 1) (Tysdal, 2000b). The diamictite unit thins westward in the Lemhi Range; it apparently pinches out at the east edge of the Salmon River Mountains (Connor, 1990; Tysdal and Moye, 1996). In the Salmon River Mountains, the coarse siltite unit correlates with part of the sequence of strata that Connor 


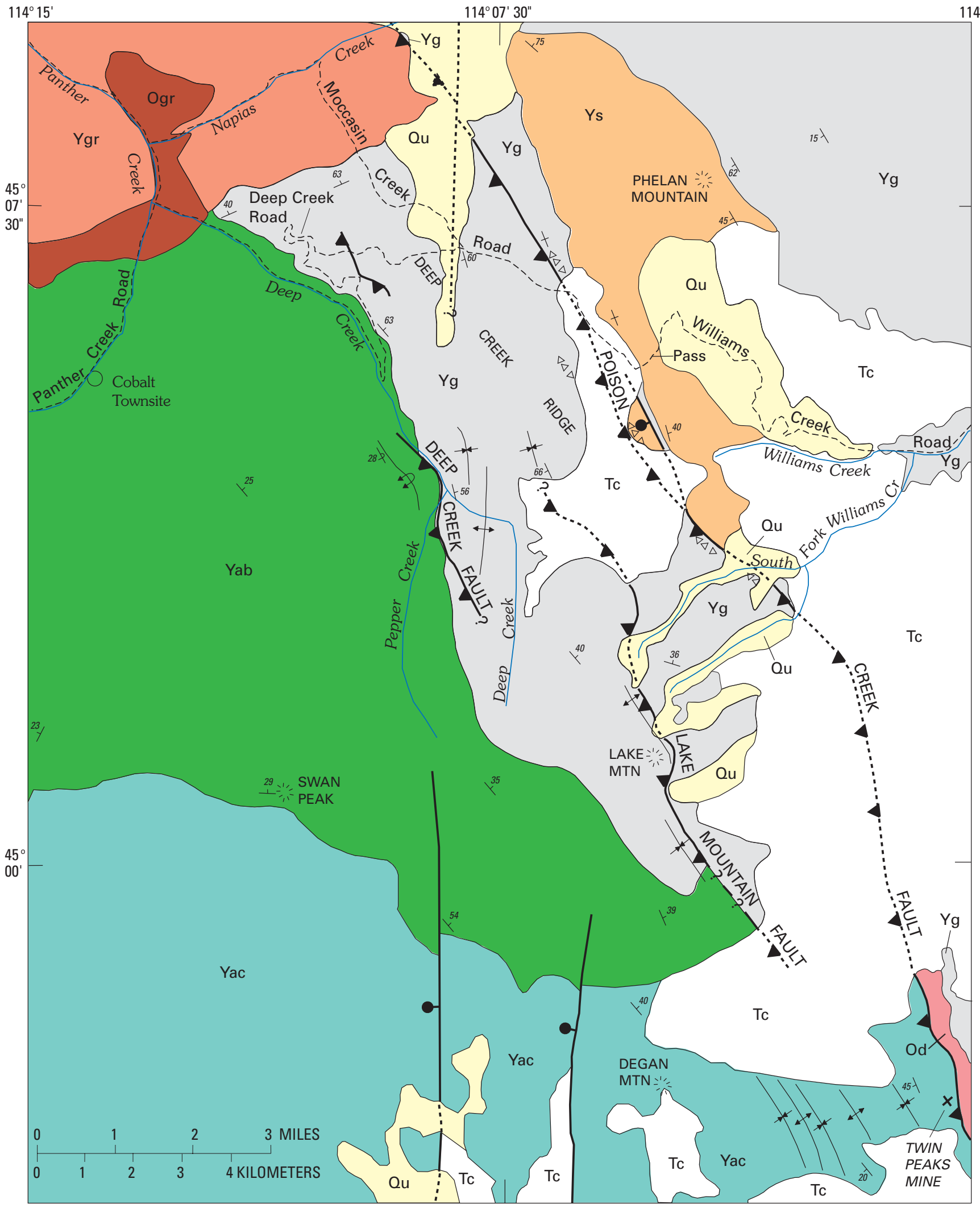

Figure 3 (above and facing page). Lake Mountain to Deep Creek area, Salmon River Mountains, showing Poison Creek thrust fault.

and Evans (1986) and Connor (1990) called the "lower subunit of the Yellowjacket Formation," as Connor $(1990,1991)$ recognized. In my revision of the Yellowjacket, I (Tysdal, 2000a) reassigned these Yellowjacket strata to the Apple Creek Formation. Rocks assigned to the Yellowjacket Formation previously were restricted to terrain south of the Iron Lake fault (Tysdal, 2000a). These changes in nomenclature are based on mapping and stratigraphic studies (Tysdal, 1996a, 1996b, 1996c, 2000a, 2000b; Tysdal and Moye, 1996) conducted in the Lemhi Range subsequent to the mapping of Connor and Evans (1986), Connor $(1990,1991)$, and Evans and Connor (1993) in the Salmon River Mountains. 


\section{EXPLANATION}

\begin{tabular}{|c|c|}
\hline Qu & Quaternary sediments, undivided \\
\hline Tc & Eocene Challis Volcanic Group \\
\hline Od & Ordovician dolomite \\
\hline Ogr & Ordovician granitic rocks \\
\hline & Mesoproterozoic units \\
\hline Ygr & Granitic intrusive rocks \\
\hline Ys & Swauger Formation \\
\hline Yg & Gunsight Formation \\
\hline & Apple Creek Formation \\
\hline Yab & Banded siltite unit \\
\hline Yac & Coarse siltite unit \\
\hline & Contact \\
\hline - & $\begin{array}{l}\text { Normal fault--Dotted where concealed; } \\
\text { bar and ball on downthrown side }\end{array}$ \\
\hline & $\begin{array}{l}\text { Thrust fault--Dotted where concealed, } \\
\text { queried where uncertain; sawteeth on } \\
\text { upper plate }\end{array}$ \\
\hline$t$ & Syncline--Showing trace of axial plane \\
\hline$\uparrow$ & Anticline--Showing trace of axial plane \\
\hline & $\begin{array}{l}\text { Overturned anticline--Showing trace } \\
\text { of axial plane }\end{array}$ \\
\hline$\triangleleft \triangleright \nabla$ & Breccia \\
\hline & Strike and dip of beds \\
\hline$x^{64}$ & Inclined \\
\hline+ & Vertical \\
\hline $40 \nmid$ & Overturned \\
\hline X & Mine \\
\hline
\end{tabular}

In the Salmon River Mountains, a stratigraphic unit assigned to the "middle subunit of the Yellowjacket Formation" by Connor and Evans (1986) lies conformably above the coarse siltite unit of the Apple Creek Formation. This stratigraphic unit, almost entirely absent from the Lemhi Range, is recognized as a facies of the Apple Creek Formation and is here renamed the "banded siltite unit," an informal name that was used originally by Connor and Evans (1986). Strata assigned to the "upper subunit" of the Yellowjacket Formation by Connor and Evans (1986) are correlated with the Gunsight Formation, to which they are reassigned. Most of this unit lies on the footwall McDevitt Creek thrust sheet.

\section{Terminology}

Proterozoic rocks throughout most of the region discussed here have been metamorphosed to the greenschist facies. Chlorite-grade metamorphism is typical of most of the rocks in the Lemhi Range, although biotite-grade rocks are common in the northwesternmost part of the range (north of Poison Peak, fig. 1). Biotite-grade metamorphism characterizes most of the rocks in the east-central part of the Salmon River Mountains. In this report, the following terminology is used for the clastic rocks.

Argillite. Metamorphosed claystone.

Siltite. Metamorphosed siltstone or mudstone.

Mudstone. Rock composed of a mixture of silt- and clay-size grains; may contain a small percent of sand-size grains.

Metasandstone. Metamorphosed sandstone; generally applied only to rocks composed of less than 90 percent quartz grains.

Quartzite. Metamorphosed sandstone composed of at least 90 percent quartz grains.
Table 1. Correlation diagram for Mesoproterozoic formations in hangingwall and footwall of Poison Creek thrust sheet (fig. 2) in western part of Lemhi Range and eastern part of Salmon River Mountains. The Big Creek Formation in the Salmon River Mountains is reassigned to the Swauger Formation, and the directly underlying rocks are assigned to the Gunsight Formation. The contact of the two formations is conformable, as originally interpreted by Shockey (1957), and is not a thrust fault as later interpreted by Connor and Evans (1986).

[No thickness of formations is implied. Height of boxes is greater for some units to accommodate different nomenclature and (or) subdivisions of formations]

\begin{tabular}{|c|c|c|c|}
\hline & $\begin{array}{l}\text { LEMHI RANGE } \\
\text { AND } \\
\text { SALMON RIVER } \\
\text { MOUNTAINS }\end{array}$ & & $\begin{array}{l}\text { SALMON RIVER } \\
\text { MOUNTAINS }\end{array}$ \\
\hline \multicolumn{2}{|c|}{$\begin{array}{l}\text { Tysdal (2000a, 2000b) } \\
\text { THIS REPORT }\end{array}$} & \multicolumn{2}{|c|}{$\begin{array}{l}\text { Connor and Evans (1986), } \\
\text { Connor (1990), Evans and } \\
\text { Connor (1993), Evans (1999) }\end{array}$} \\
\hline \multicolumn{2}{|c|}{ Swauger Formation } & \multicolumn{2}{|c|}{$\begin{array}{l}\text { Big Creek Formation } \\
\text { (thrust fault at base) }\end{array}$} \\
\hline \multirow{2}{*}{\multicolumn{2}{|c|}{ Gunsight Formation }} & \multirow{5}{*}{ 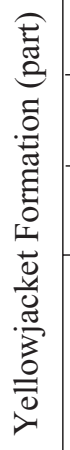 } & Upper subunit, upper part \\
\hline & & & Upper subunit, lower part \\
\hline \multirow{4}{*}{ 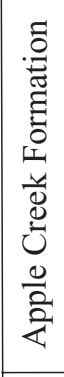 } & Banded siltite unit & & Middle subunit \\
\hline & Coarse siltite unit & & \multirow{2}{*}{ Lower subunit (part) } \\
\hline & Diamictite unit & & \\
\hline & Fine siltite unit & \multirow{2}{*}{\multicolumn{2}{|c|}{$(* *)$}} \\
\hline \multicolumn{2}{|c|}{ Big Creek Formation } & & \\
\hline
\end{tabular}

**Lower subunit (remaining part)_-Included conformable sequence of Yellowjacket Formation as restricted by Tysdal (2000a), Hoodoo Formation, and unnamed argillaceous quartzite unit. These units were not correlated with strata in Lemhi Range (left column).

Orthoquartzite. Metamorphosed sandstone composed of at least 95 percent quartz grains.

\section{Apple Creek Formation}

\section{Lemhi Range}

The fine siltite unit, the diamictite unit, and the coarse siltite unit constitute the Apple Creek Formation of the Poison Creek thrust sheet. The thickness of the three units totals 4,000-5,000 m. These three units are described briefly here because they set a context for the stratigraphic and sedimentologic interpretation of the banded siltite unit of the Salmon River Mountains. The coarse siltite unit, the upper unit in the 
Lemhi Range, is widespread in the Salmon River Mountains as well, where it conformably underlies the banded siltite unit.

\section{Fine Siltite Unit}

The fine siltite unit of the Apple Creek Formation of the Poison Creek thrust sheet is planar-laminated siltite, ripple crosslaminated siltite, and argillaceous siltite. Many beds are graded, with 1-2 cm thick layers of siltite grading upward into argillite. The unit locally contains matrix-supported granule- to pebblesize argillite clasts. Rippled beds within the fine siltite unit are attributed to reworking by bottom currents. Graded-stratified siltite is common, forming bands of coarse-grained siltite to finegrained metasandstone that are of finest grain size in the upper part; uppermost parts of some bands grade to fine-grained siltite, but argillite is absent. These strata fit the Bouma (1962) sequence of graded turbidite beds (Tysdal, 2000b).

\section{Diamictite Unit}

Poorly sorted, matrix-supported conglomerate-diamictite-characterizes a succession of otherwise fine-grained strata within the Apple Creek Formation of the Poison Creek thrust sheet. Most of the diamictite beds are composed of disorganized matrix-supported clasts; they are interpreted as turbidites or debris flows. Argillite, argillaceous siltite, siltite, and lesser metasandstone form successions as much as $10 \mathrm{~m}$ or more thick between the diamictite beds. Grading is obvious where deformation is not intense, and Bouma sequences are most prominent in the upper part of the unit. Paleocurrent directions determined from current ripples reveal transport from both the northeast and southwest. These fine-grained (non-conglomerate) strata are attributed to a turbidite origin (Tysdal, 2000b).

\section{Coarse Siltite Unit}

The coarse siltite unit is composed of gray-green mediumto coarse-grained siltite and fine-grained metasandstone. Siltite beds observed are normally graded. Soft-sediment deformation structures are widespread: ball-and-pillow structures are fairly common; flute casts and tool marks were observed only locally. The unit derives its name from distinctive graded beds of sharpbased light-gray, quartz-rich, fine-grained metasandstone interspersed within the sequence. The graded bedding of the siltite and the sharp-based light-gray metasandstone beds suggest deposition from turbidity currents (Tysdal, 2000b).

\section{Salmon River Mountains}

\section{General Setting of Banded Siltite Unit of Apple Creek Formation}

Figure 4 shows the general southwest-northeast interpreted facies relationships for the banded siltite unit of the Apple Creek Formation for the area of the Salmon River Mountains shown in figure 3. The banded siltite unit includes turbidites (lower strata of unit) and current-reworked turbidites (upper strata of unit). The directly overlying Gunsight Formation consists of hummocky crossbedded storm deposits, shoreface strata, and fluvial rocks. The fluvial strata are thought to be separated from the marine strata by an erosion surface that cuts downward stratigraphically toward the west. Fluvial rocks lie on the shoreface strata in the eastern part of the Salmon River Mountains and on storm-reworked turbidites on the west (fig. 3, Deep Creek road area).

The lithofacies of the banded siltite unit of the Apple Creek Formation are described and interpreted in this section. Hummocky, shoreface, and fluvial lithofacies are described and interpreted in the section on the Gunsight Formation.

\section{Banded Siltite Unit}

The banded siltite unit of the Apple Creek Formation was examined in some detail by Sobel (1982) during a thesis study of a $10 \mathrm{~km}^{2}$ area in the vicinity of the Blackbird mine (fig. 2), which hosts most of the stratabound cobalt- and gold-bearing deposits of the district. Sobel's (1982) study of the banded siltite unit was part of extensive work by NORANDA, Inc., during mineral exploration and mining of cobalt. The mineral deposits are not a part of the present report, but they are mentioned because my findings herein bear on the stratigraphic and structural setting of the deposits.

Sobel (1982) recognized three distinct facies, in ascending order: graded siltite, rippled "quartzite," and laminated "quartzite" for the banded siltite unit. Upper strata of his sequence include rocks that Evans and Connor (1993) placed in the upper part of the banded siltite unit and lower part of the overlying Gunsight Formation (upper part of the "middle subunit of the Yellowjacket Formation" and lower strata of the "upper Yellowjacket," respectively, of their nomenclature). Sobel's (1982) lower two lithofacies are discussed next, in "Lower Strata of the Banded Siltite Unit." Strata of his uppermost unit, the laminated quartzite facies, are similar to rocks that I describe in the section entitled, "Upper Strata of the Banded Siltite Unit."

\section{Lower Strata of the Banded Siltite Unit}

In his study of rocks in the vicinity of Blackbird Creek, Sobel (1982, p. 112, 117) described a stratigraphic succession that displays an upward increase in grain size, bed thickness, and abundance of sandy beds. His graded siltite and overlying rippled "quartzite" lithofacies contain sharp-based, normally graded beds of incomplete Bouma (1962) $\mathrm{T}_{\mathrm{bc}}, \mathrm{T}_{\mathrm{cde}}$, and $\mathrm{T}_{\mathrm{de}}$ sequences; no complete $\mathrm{T}_{\mathrm{a}}$ through $\mathrm{T}_{\mathrm{e}}$ sequences were observed. The graded siltite lithofacies consists of thin beds that grade upward from fine-grained metasandstone to siltite. Other features include ripple crosslaminae and soft-sediment deformation features - water-escape structures, intrastratal slides, and convoluted laminae.

The rippled quartzite lithofacies consists of thin- to medium-bedded metasandstone that contains ubiquitous 


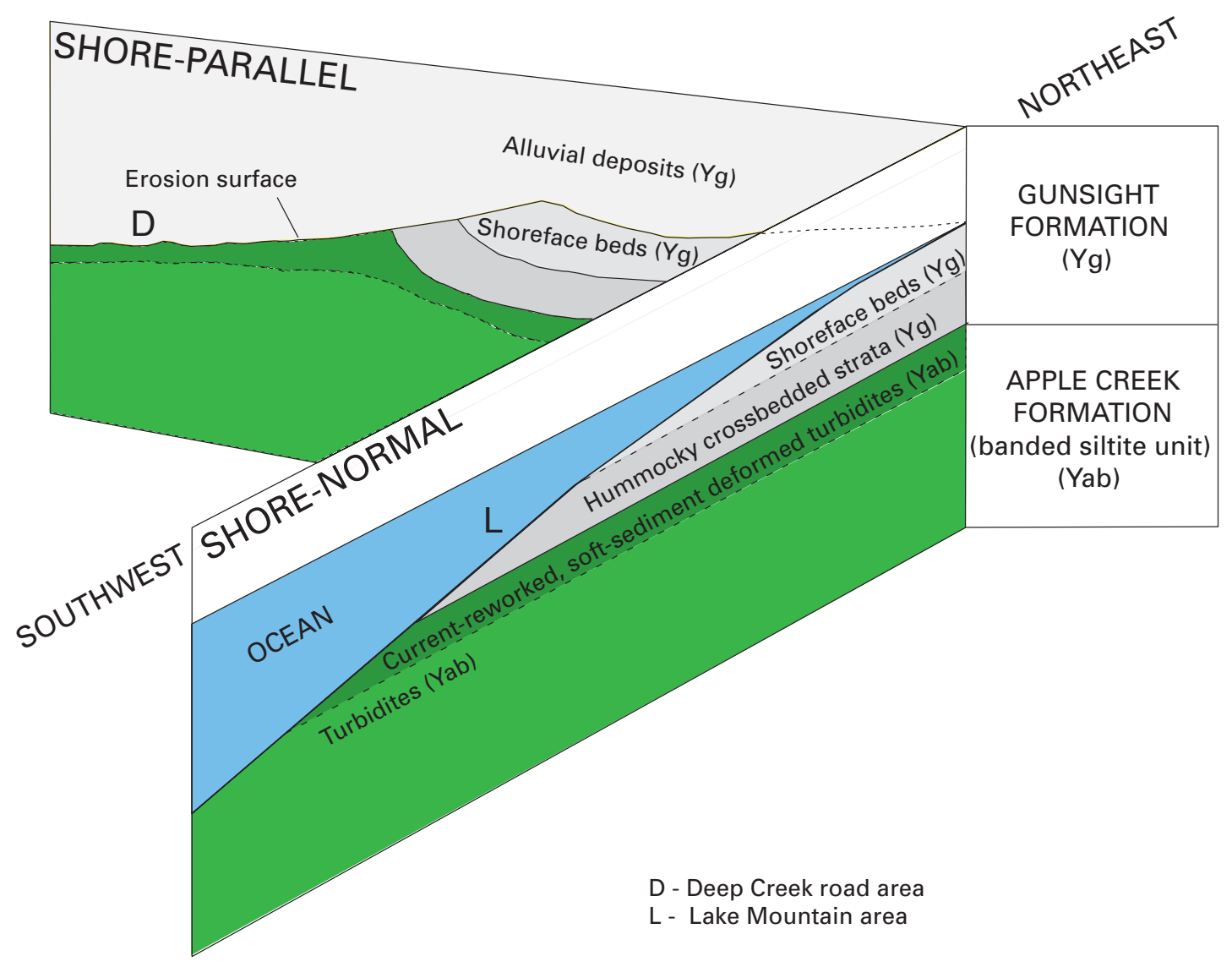

Figure 4. Diagrammatic illustration of general facies relationships interpreted for strata within the banded siltite unit of the Apple Creek Formation and the overlying Gunsight Formation in the eastern part of the Salmon River Mountains. The figure illustrates the relationships for strata southwest of Poison Creek thrust fault as shown in figure 3-that is, on Poison Creek thrust sheet. Shore-normal section shows ocean position during deposition of units. No relative thickness of units is implied.

crosslamination and rippled bedding surfaces, and thin interbeds of graded siltite or siltite to argillite. Less common features include rip-up clasts, scours, sole marks, and horizontal lamination. Soft-sediment deformation structures include "crumpled mud cracks," water-escape structures, wavy and convolute laminae, load structures, and microfaults. In many places, metasandstone beds terminate abruptly against strata deformed during soft-sediment deformation (Sobel, 1982).

Sobel (1982) interpreted the strata to be deposits of a submarine fan system, formed of distal turbidites of a basin plain, outer fan and interlobe deposits (fan fringe), and mid-fan (suprafan lobes). The intrastratal folding and deformed shrinkage cracks were interpreted as deposits formed from gravity sliding on a slope. Vertical and horizontal water-escape features of the rippled quartzite lithofacies were interpreted to indicate gravity sliding and compaction deformation during sedimentation. Sand layers commonly were caught between sliding sediment masses, resulting in crumpled, contorted, disrupted beds (Sobel, 1982, p. 144-157).

Many of the sedimentary structures that Sobel (1982) described in his study area are widespread in the banded siltite unit in the Salmon River Mountains. Some of these-creep and slump deposits, "shrinkage cracks," and dikelets (fig. 6) - are genetically related to one another and are examined in this report under the heading, "Soft-Sediment Deformation Features." Reconnaissance shows that other rock types, in addition to those described by Sobel (1982), occur outside his study area; they are described generally in following paragraphs.

Finely Laminated Strata

Finely laminated strata (fig. 5) form sequences 1-10 m or more thick and are interlayered with coarser turbidites - coarsegrained siltite to locally fine grained metasandstone - throughout most of the lower strata of the banded siltite unit. The laminae are sharply defined and commonly are $0.3-2 \mathrm{~mm}$ thick, locally $10 \mathrm{~mm}$ thick. Thicker laminae grade from coarse to medium silt and to clay-size. Thinner laminae also are graded, based on color change of darkening upward. The silt laminae are discontinuous, tapering out laterally, and display sharp bases. Fluid-escape structures were observed in a few of the thicker layers; overlying layers show no deformation. Other, less common features include $1^{\circ}-2^{\circ}$ angular relationships where one lamina oversteps underlying laminae; micro-crosslaminae, with erosion into underlying laminae; boudinage structures that are several centimeters across; micro-load structures, $1-5 \mathrm{~mm}$ in diameter; and convolute laminae. Laminae are normally graded: 


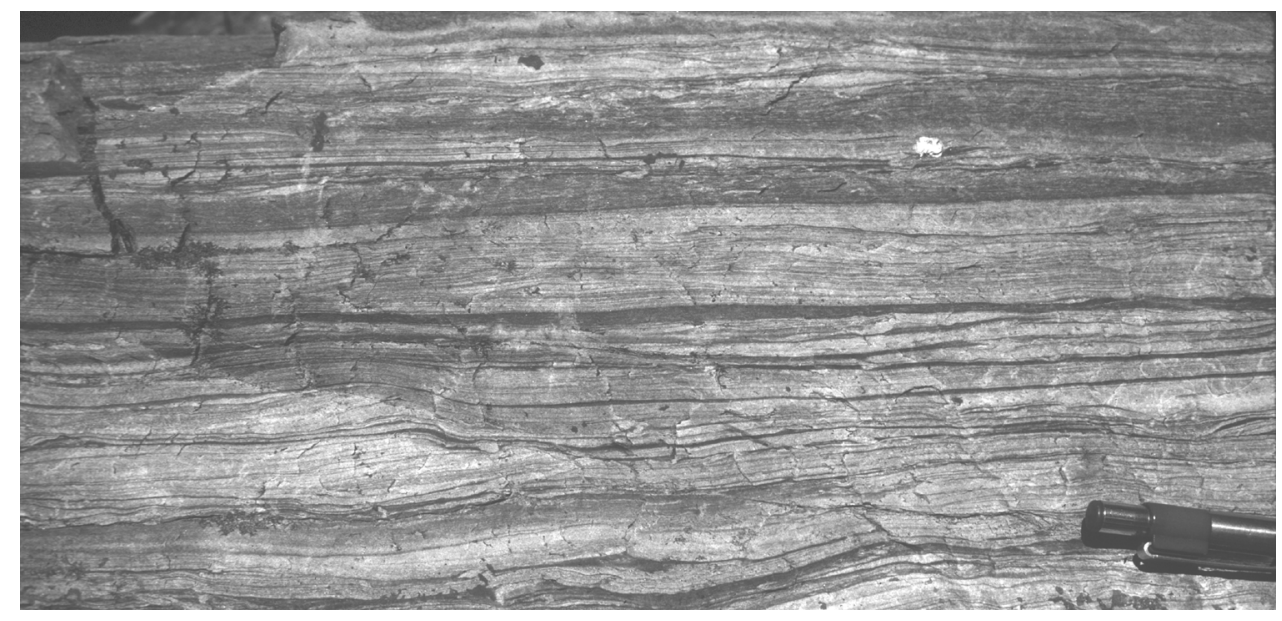

Figure 5. Finely laminated strata in banded siltite unit of Apple Creek Formation. Woodtick Creek (fig. 1) in the Salmon River Mountains. Pencil segment $5 \mathrm{~cm}$ long.

no reverse grading was observed. Some single laminae, or several laminae together, thicken and thin laterally over $5 \pm \mathrm{cm}$; laminae are thin in troughs and thick over what may be ripple crests.

The sharply defined laminae are interpreted as products of suspension sedimentation and correspond to the Bouma $\mathrm{T}_{\mathrm{d}}$ division and the $T_{2}$ to $T_{4}$ intervals ${ }^{2}$ of Stow and Shanmugam (1980). The abrupt, intermittent occurrence of the sequences of finely laminated strata within coarser grained turbidites suggests a periodically operating process of deposition. The sequences may have been deposited from waning, dilute turbidity currents in a slope (fan) environment. Alternatively, the finely laminated turbidites may have formed of sediment spilled over a levee that flanked a submarine channel down which turbidity currents flowed. Spillover levee deposits contain only the finer grained sediment of channelized turbidites (Stacey and Bowen, 1988). Sediment cored from modern levee deposits of the Amazon Channel off Brazil, for example, contains turbidites composed of fine silt and clay. From photographs of thin sections (Hiscott and others, 1997, fig. 14, p. 72), these turbidites appear to be similar to the finely laminated rocks observed near Woodtick Creek.

\section{Soft-Sediment Deformation Features}

The lower strata of the banded siltite unit contain several sedimentary features that are widespread in the unit and that have been examined in some detail by several authors. Sobel (1982) described creep and slump structures, and shrinkage cracks. Evans (1981) and Connor and Evans (1986) described dikelets. Each of these features is described separately, citing the appropriate references. From observations throughout the banded siltite unit, Tysdal (unpub. data, 1998) determined that the three kinds of features are genetically related to one another. Dikelets formed during soft-sediment deformation. The "shrinkage cracks" described and pictured by Sobel (1982, his figs. 33A, 34A) were produced during the same soft-sediment deformation process.

\footnotetext{
${ }^{2}$ The classification of Stow and Shanmugam (1980) is for fine-grained turbidites. Subdivisions used in the classification range from $T_{0}$ to $T_{8}$ and correspond approximately to the $T_{c}$ through $T_{e}$ subdivisions of the Bouma (1962) classification. The $T_{2}$ to $T_{4}$ intervals correspond approximately to the upper half of the $T_{d}$ and lower half of the $T_{e}$ intervals of Bouma (1962).
}

Creep and Slump Structures. Soft-sediment deformation structures occur in zones that are sandwiched between undeformed strata, are only a few layers thick, and commonly are disorganized within the deformed beds (Sobel, 1982, p. 43). The zones contain wavy and contorted laminae, flame structures, convolute bedding, interstratified folds, and crumpled beds that appear to have been caught between sliding masses of sediment. Crosslamination commonly is deformed. Sobel (1982, p. 46) interpreted the deformation to involve rapid sedimentation of waterlogged sediment, and his discussion indicates that he favored gravity-driven sliding as the cause of the soft-sediment deformation.

Shrinkage Cracks. Metasandstone-filled shrinkage cracks occur in 1-5 mm thick argillite (siltite) beds. Sobel (1982) stated that they display four characteristics: (1) cracks are spindle shaped or sinuous; no polygons were observed; (2) cracks commonly are associated with ripples, and crosslaminae occur in ripple troughs; (3) short cracks are oriented parallel or subparallel to one another; and (4) only one generation of cracks is present. Stating that the cracks are not like those produced by subaerial exposure, he attributed them to syneresis, the subaqueous dewatering of muddy sediment (Sobel, 1982, p. 123).

Dikelets. The term "dikelets" was introduced by Connor and Evans (1986), following recognition of the features by Evans (1981), to refer to small, tabular dikes of siltite that generally range from about 5 to $10 \mathrm{~mm}$ high and from 2 to $5 \mathrm{~mm}$ wide, and which project downward from the base of beds (fig. 6). Evans (1981) called them “***characteristic downward-penetrating, silt-filled 'dikelets' of unknown origin.” Their depositional environment also was of uncertain origin, but the dikelets were considered critical to definition of the banded siltite unit (the "middle subunit of the Yellowjacket Formation" of Connor and Evans, 1986). I concluded (Tysdal, unpub. data, 1998) that the dikelets are not primary depositional structures but were produced during soft-sediment deformation. The deformation is related to slow mass-movement downslopecreep-of water-rich sediment.

\section{Upper Strata of the Banded Siltite Unit}

Upper strata of the banded siltite unit are well exposed in cuts along the Deep Creek road (fig. 3), and along a logging road 


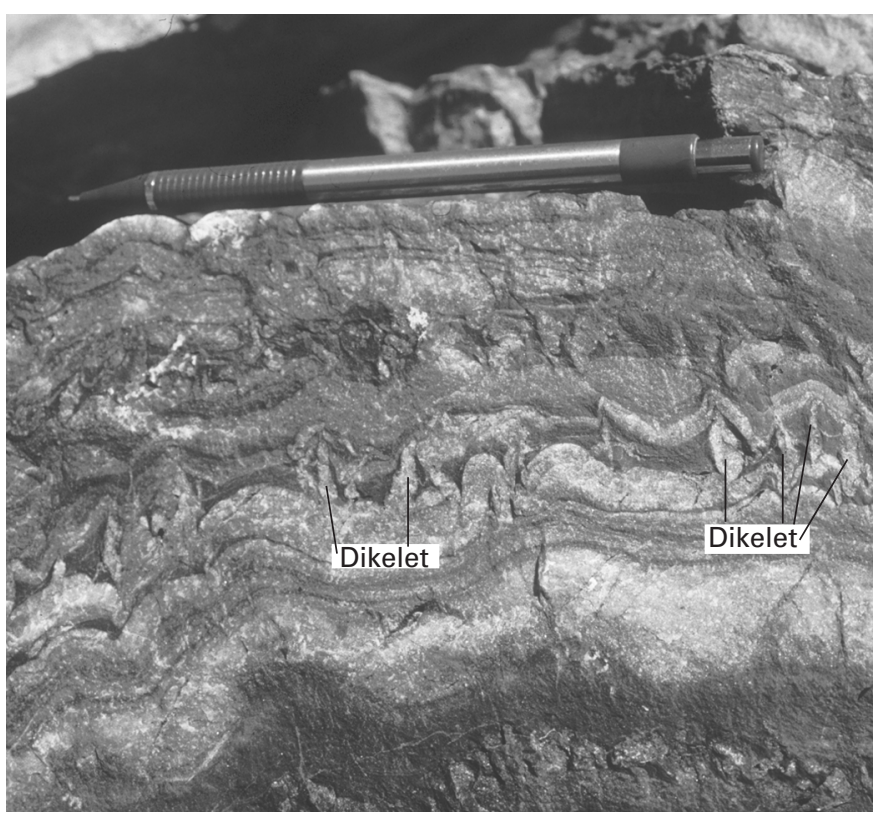

Figure 6. Dikelets in banded siltite unit of Apple Creek Formation, from Swan Peak (fig. 3). Pencil $13 \mathrm{~cm}$ long.

west of Deep Creek just below its junction with Pepper Creek (this road is not shown in fig. 3). The strata typically form 5-10 $\mathrm{cm}$ thick beds of light-gray fine-grained metasandstone to coarse-grained siltite and interlayered dark-gray siltite (metamudstone) or, locally, argillite (fig. 7).

Two prominent characteristics are recorded in the upper strata: eroded upper surfaces of metasandstone beds and softsediment deformation features. The lower surfaces of the lightgray beds commonly display sharp contacts. The beds generally are planar laminated, but some display planar laminae that grade upward into crosslaminae, then into dark-gray siltite - a Bouma $\mathrm{T}_{\mathrm{bcd}}$ sequence. In other cases, the upper surface of the metasandstone beds clearly is reworked, erosional: the upper surface of crossbeds is overlain by laminated dark-gray siltite deposited across truncated crosslaminae (fig. 8). In still other strata, the dark-gray siltite fills, or partly fills, irregularities (such as ripple troughs) of the underlying sediment, whereas the upper surface of the siltite "fill" is planar, flat laminated. Normal to transport direction, the base of metasandstone beds ranges from parallel to the underlying siltite to moderate or steep dip of ripple-foreset laminae. In contrast to most of the strata of the banded siltite unit, the upper strata generally lack the small (1-5 $\mathrm{mm}$ ) load structures, dikelets, and the "syneresis cracks" associated with creep or slump folds. Small-scale slump folds are fairly common, however.

As discussed in the section entitled, "Lower Strata of the Banded Siltite Unit," Sobel (1982) recognized three distinct lithofacies in his map area (shown in fig. 2). The lower two lithofacies - graded siltite and rippled quartzite-were discussed in that section. His upper lithofacies - laminated "quartzite" - is discussed here because its sedimentary features are similar to those described in the previous paragraph. Sobel (1982) described his laminated quartzite lithofacies as consisting of about 90 percent metasandstone and argillaceous metasandstone. Siltite and argillite make up the rest. Other features include ripple crosslaminae, local climbing ripples, and small channels. He noted that upper surfaces of the crosslaminated siltite and metasandstone beds commonly are eroded and may have been reworked by bottom currents. My observations along Deep Creek show that the ripple crosslaminated beds contain both complete ripples and ripples with eroded crests. Eroded crests have been interpreted as products either of bottom currents (Shanmugam and others, 1993; Shanmugam, 1997) or of normal turbidity current processes (Stow and others, 1998).

Soft-sediment deformation features are abundant in the upper strata of the banded siltite unit in the Deep Creek area (figs. 7, 8), a significant difference from their absence in the laminated quartzite strata of Sobel's (1982) small study area (fig. 1). Thin, laterally discontinuous beds of light-gray metasandstone (or coarse siltite) are interlayered with dark-gray fine siltite beds of variable thickness. The thinned and tapered beds and the variably thick siltite are here interpreted to indicate flowage of water from water-rich silt. An "extreme" case of soft-sediment deformation is shown in figure 9, where a metasandstone bed is "broken"- pulled apart. The sand bed likely was deposited on top of water-saturated silt and the loading caused the water to flow, rupturing the sand bed.

Folds here attributed to soft-sediment slumping occur locally within the upper strata of the banded siltite. Folds as much as $30 \mathrm{~cm}$ high are underlain and overlain by beds of unfolded strata. Dikelets also are present locally within the softsediment deformed rocks and are associated with flowage of water-saturated sediment (fig. 10).

The upper strata of the banded siltite unit are here interpreted as turbidites that have been disturbed-partly reworked by storm-generated currents and deformed to some extent during adjustment to the high water content of the sediments at the time of deposition. Upper beds are interbedded with lower rocks of the overlying hummocky strata, interpreted as storm deposits, of the Gunsight Formation. They probably were deposited on a submarine slope or a fan. The graded beds interlayered in the upper strata of the banded siltite unit display Bouma $\mathrm{T}_{\mathrm{bcd}}$ features that could be either turbidites or stormgenerated deposits. If turbidites, then some or many of the light-gray metasandstone to coarse-grained siltite beds that display reworked upper parts may be turbidites reworked by storm-generated currents. Each overlying sharp-based darkgray siltite bed then could be composed of suspension sediments precipitated from a waning storm current. Sobel (1982) stated that the vertical bed sequences diagnostic of turbidity currents are lacking in his study area, but he did recognize current-reworking of beds.

The abundant soft-sediment deformation features of the upper strata of the banded siltite unit indicate a high water content for the sediments, particularly the silt-rich strata. Adjustment to the high water content produced such deformation features as water-escape structures; metasandstone beds that taper normal to the direction of transport (southwest), or are abruptly truncated where water-saturated silt flowed across (as seen in cross section) "broken" metasandstone beds; local slump folds; and local dikelets. The major adjustments took 


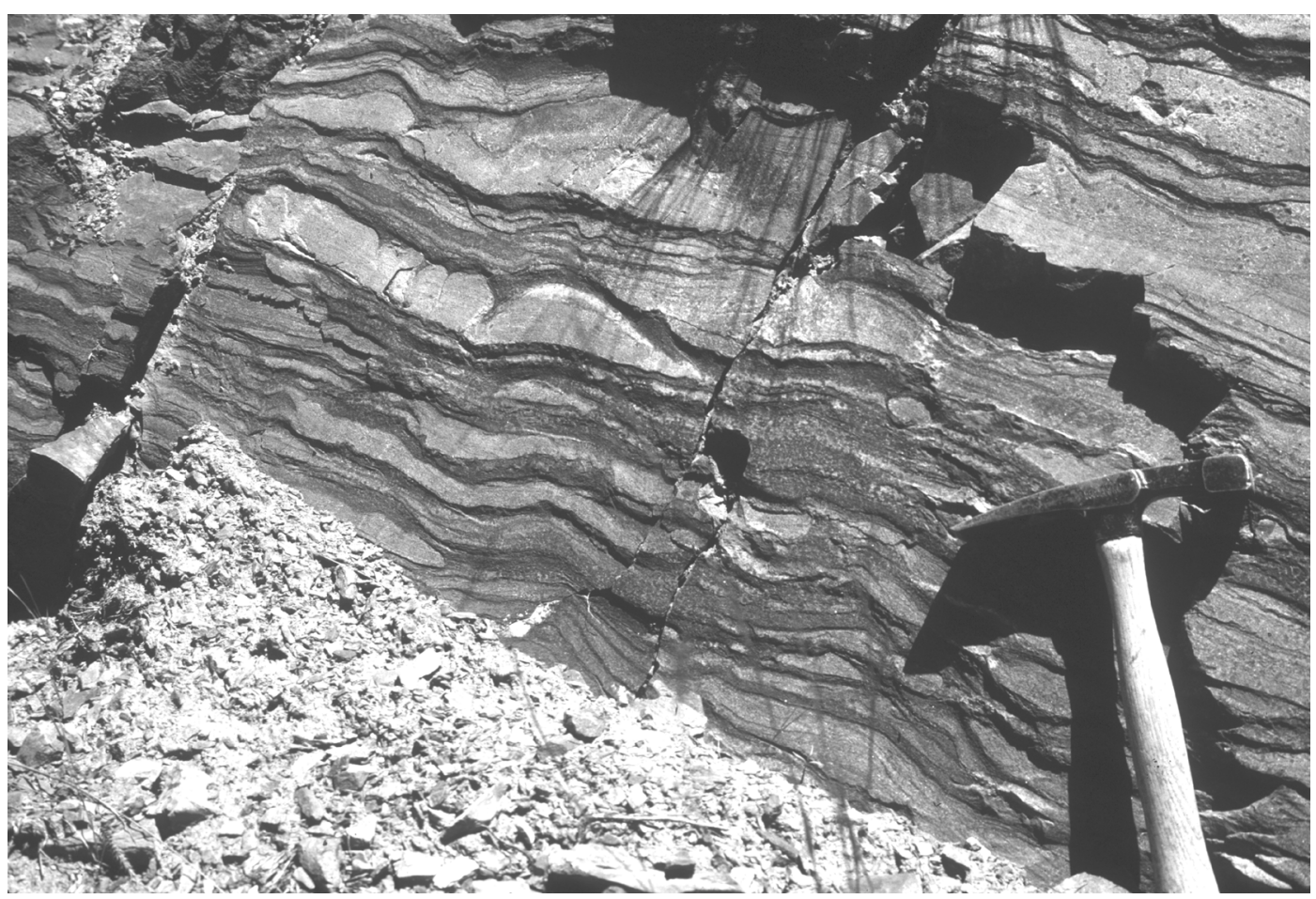

Figure 7. Typical outcrop of upper strata of banded siltite unit of Apple Creek Formation, showing interlayered beds of light-gray metasandstone and dark-gray siltite. Note laterally discontinuous metasandstone beds, some tapering and others abruptly truncated. Irregular thickness of metasandstone and siltite beds is interpreted to indicate soft-sediment deformation, adjustment of strata to escape of water from water-saturated silt during and shortly after deposition of strata. Deep Creek road area of Salmon River Mountains. Hammer head 20 $\mathrm{cm}$ long.

place during sedimentation or shortly thereafter, as shown by deformation structures that are overlapped by undeformed strata.

\section{Scapolite-Rich Beds}

Scapolite-rich beds were reported by Connor and Evans (1986) in the upper strata of the banded siltite unit of the Apple Creek Formation (that is, their "middle subunit of the Yellowjacket Formation") along the road adjacent to Deep Creek (figs. $2,3)$. They recorded no scapolite from lower in the unit, and I also found no scapolite in the lower strata.

The scapolite occurs in the dark-gray siltite that is interbedded with light-gray coarse-grained siltite to fine-grained metasandstone of the banded siltite unit. The scapolite porphyroblasts commonly range from 3 to $10 \mathrm{~mm}$ in diameter. A few beds show a grading in porphyroblast size, from larger diameter at the base to smaller at the top. One bed shows smaller diameter porphyroblasts at the base compared to larger at the top. Still other scapolitic beds show porphyroblasts of uniform size throughout a bed, or of different sizes but with no systematic size changes. The scapolitic dark-gray siltite beds do not display sedimentary structures that differ from those of the nonscapolitic dark-gray siltite. No scapolite was observed in the directly adjacent light-gray clastic beds. I did not find a change in sedimentary structures above and (or) below the scapolitic beds that would suggest a change in the depositional environment. The scapolitic beds do not appear to display a systematic or rhythmic pattern of occurrence within the upper part of the banded siltite unit.
Some beds along the Deep Creek road display 1-5 mm diameter light-gray spots, which appeared as if they may be clots of scapolite; samples of the material were collected from three outcrops. Two samples are from the uppermost part of the banded siltite unit of the Apple Creek Formation, and one is from basal strata of the overlying Gunsight Formation. Xray examination of these spotted rocks showed only a trace of scapolite; the chief minerals in the two rocks are quartz+phlogopite+albite \pm potassium feldspar (G.A. Desborough, written commun., 1997; oral commun., 1998). The spots may be due to contact metamorphism related to concealed igneous rocks.

The scapolite-rich beds were interpreted, with some question, as metamorphosed volcanogenic material by Connor and Evans (1986). This interpretation is consistent with an exhalative process of cobalt mineralization in the Blackbird mining district (Hughes, 1983; Hahn and Hughes, 1984; Nash, 1989; Nash and Hahn, 1989), and the proposal of Tysdal and Desborough (1997) that the Na- and Cl-rich biotites of the district (composition reported by Nash and Connor, 1993) reflect fluid movement upward through evaporite rocks of the Yellowjacket Formation. The volcanogenic concept does not affect the storm deposit interpretation for the non-scapolitic sedimentary rocks that make up most of the sequence.

An alternative explanation for the origin of the scapoliterich beds is that the trace scapolite may be metamorphosed $\mathrm{NaCl}$ salt crystals. Formation of the crystals requires an evaporite setting wherein $\mathrm{NaCl}$ reaches supersaturation within the water column or sediment, and is deposited, for example, within the upper part of an intertidal to supratidal zone. This 


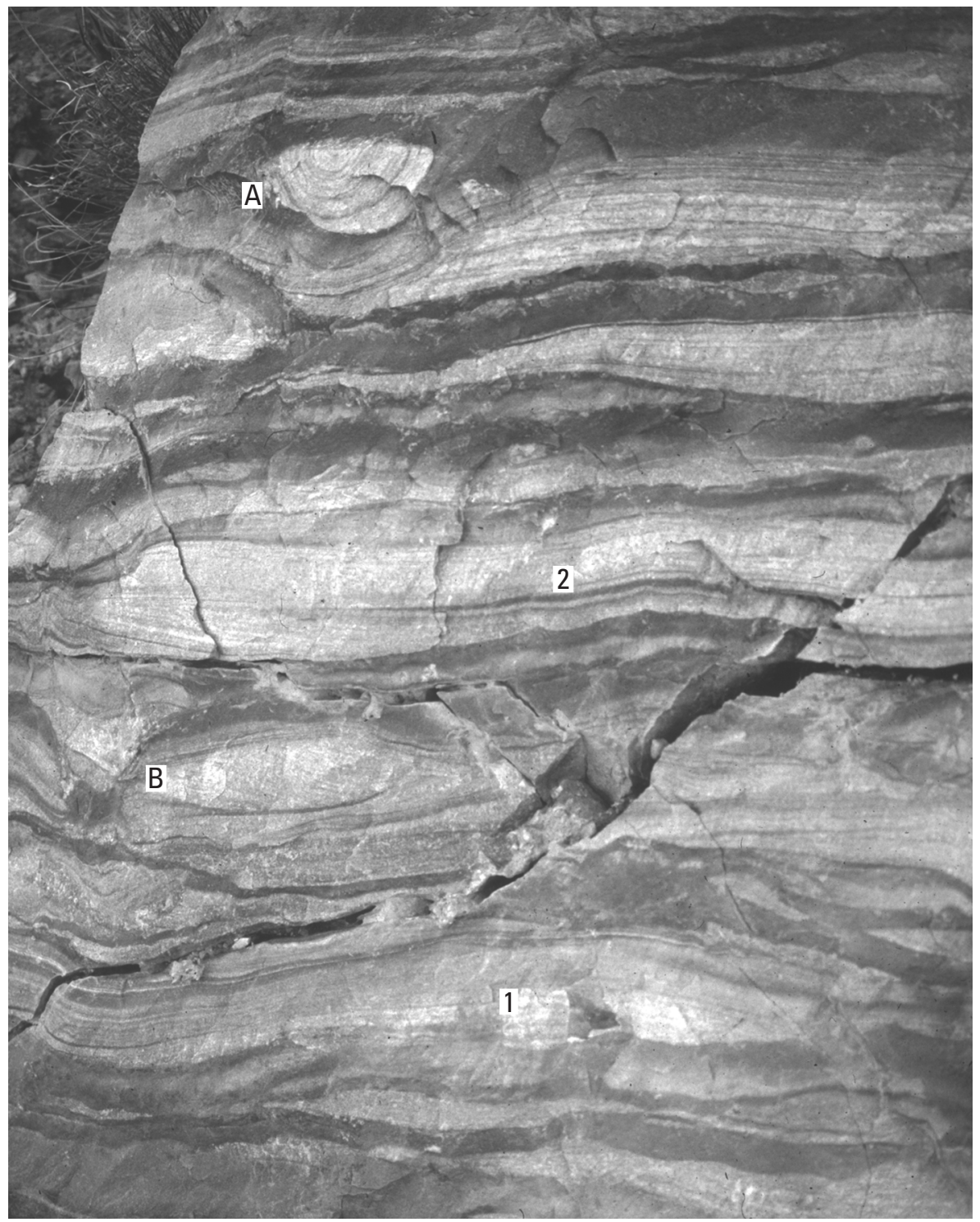

Figure 8. Detailed view of upper strata of banded siltite unit of Apple Creek Formation. Note the following: Loc. A-metasandstone deformed into "syncline," and overlain by undeformed siltite and metasandstone. Loc. B—crosslaminae of metasandstone bed show angular discordance with directly overlying metasandstone and siltite. Metasandstone beds 1 and 2 show minor disturbance, but strata between the two beds show significant disruption, indicating that the soft-sediment deformation \pm erosional history of the strata between beds 1 and 2 differs. Deep Creek road area of Salmon River Mountains. Thickness of strata in photograph about $50 \mathrm{~cm}$.

explanation is discounted because the host banded siltite unit is believed to represent offshore storm deposits; nevertheless, several arguments are presented to discount the interpretation. The dark-gray siltite beds, and the interbedded coarse siltite to finegrained metasandstone beds, do not contain textures of evaporites. The beds lack mudcracks, ripples, small-scale convolute lamination, rip-up clasts, and other features suggestive of a tidal flat environment. The dark-gray scapolitic and non-scapolitic siltites do not display different sedimentary structures, as if the beds had originated from different processes. The dark-gray siltites are interpreted as suspension deposits, but the scapolitic and nonscapolitic rocks may have resulted from different original sources - the scapolitic rocks from an exhalative source, the nonscapolitic siltites from storm-derived silt. The light-gray clastics do not contain scapolite. But if the scapolite formed during metamorphism of $\mathrm{NaCl}$ precipitated from evaporite fluids, then I would expect both the light-gray clastics and the directly overlying dark-gray siltite to contain scapolite. The porous light-gray clastics should have contained the evaporite $\mathrm{NaCl}$-bearing precursor of the scapolite just as readily as the directly overlying dark-gray siltites.

Correlation. The scapolite-bearing rocks of the Deep Creek road area are interpreted as metamorphic products of sediments deposited in an environment different from that which existed in the area of the principal reference section of the Yellowjacket Formation. I examined outcrops along the Deep Creek road to determine if these strata contained marble (metalimestone) and interbedded sodium-rich scapolitic beds like those of the 


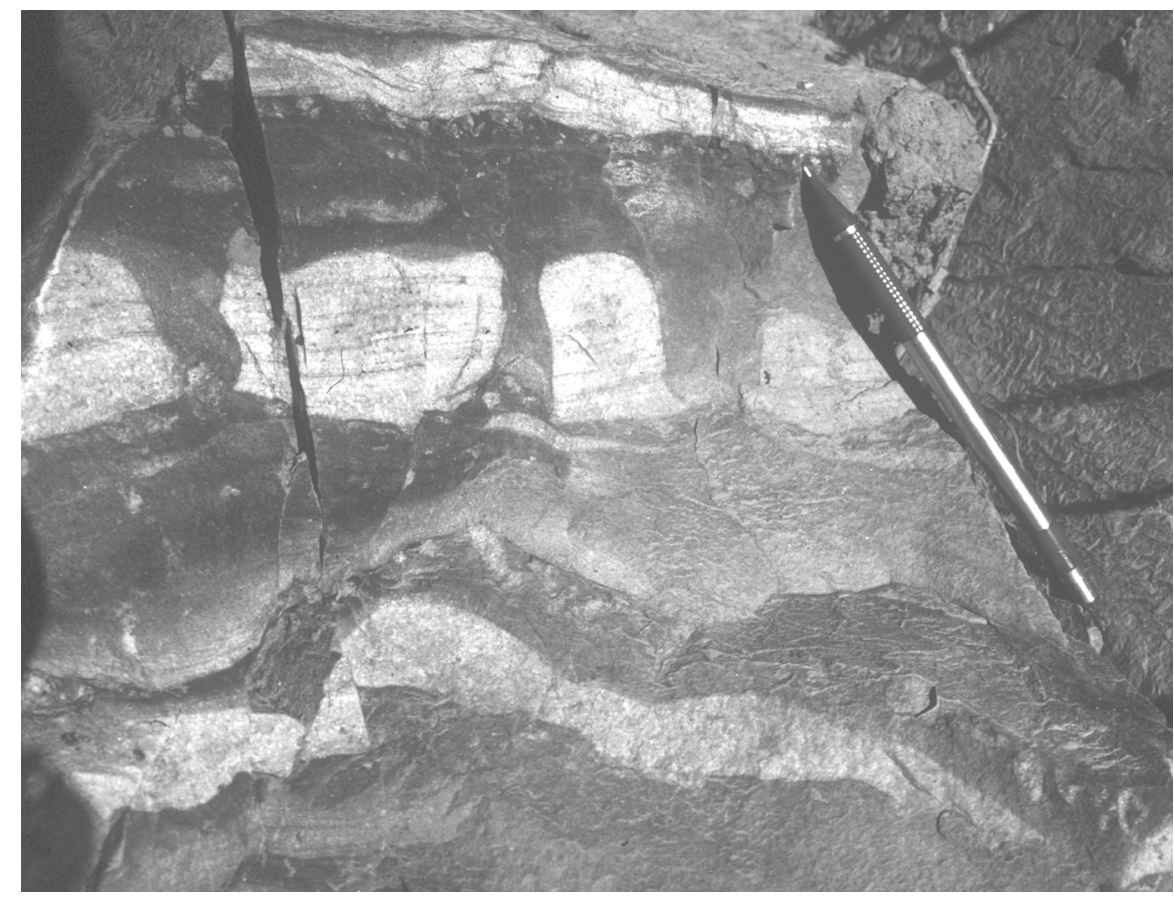

Figure 9. Light-gray metasandstone bed cut by dark-gray siltite during soft-sediment deformation. Structure interpreted to reflect loading of sandstone bed onto water-saturated silt, causing flowage of silt and disruption of the sandstone bed. Note soft-sediment deformation of strata below disrupted bed and unbroken metasandstone bed above it. Lake Mountain area of Salmon River Mountains. Pencil $13 \mathrm{~cm}$ long.

Yellowjacket Formation in the vicinity of the principal reference section $^{3}$ near the townsite of Yellowjacket, and along Moyer Creek (fig. 1), interpreted as metaevaporites by Tysdal and Desborough (1997). No marble or sodium-rich scapolitic beds were found, nor do the Deep Creek strata lie within a depositional sequence like that of the Yellowjacket. The Deep Creek scapolitic strata occur within storm-generated rocks of the Apple Creek Formation and underlie fluvial rocks of the Gunsight Formation. This contrasts with the metaevaporites of the Yellowjacket, which lie within intertidal to supratidal strata and are overlain conformably by quartzites of the Hoodoo Formation, interpreted as tidal deposits by Tysdal and Desborough (1997).

\section{Gunsight Formation}

\section{Lemhi Range}

The Gunsight Formation was named by Ruppel (1975) for a sequence of strata in the vicinity of Gunsight Peak in the central part of the Lemhi Range (fig. 1). The type locality extends north from near Yellow Lake to Gunsight Peak (Ruppel, 1975).

McBean (1983) examined the rocks of the type area as part of a thesis study of the Gunsight Formation. The following summary

\footnotetext{
${ }^{3}$ No type section exists. Naming of the Yellowjacket Formation preceded the requirement to designate a type section according to the guidelines of the North American Stratigraphic Code (North American Commission on Statigraphic Nomenclature, 1983). A section measured by Ross (1934), who named the formation for rocks in the vicinity of the townsite of Yellowjacket (fig. 1), was designated the principal reference section by Ekren (1988).
}

is from Tysdal (2000b) and is based on reconnaissance traverses through the type section. The Gunsight strata in the Lemhi Range are chiefly of fluvial origin. Trough crossbedded metasandstones form units 1-2 m thick that fine upward and give way to siltite of overbank deposits. Uppermost strata of the formation lack fine-grained beds of siltite and primarily are medium- to coarse-grained quartzite and metasandstone of quartz and feldspar. Trough crossbedding is common. These uppermost strata could be shoreface deposits transitional upward from fluvial strata of the Gunsight into the marine orthoquartzite of the overlying Swauger Formation.

\section{Salmon River Mountains}

Strata that I here place in the Gunsight Formation previously were mapped as the "upper subunit of the Yellowjacket Formation" by Connor and Evans (1986) in their study of the Leesburg $15^{\prime}$ quadrangle (lat $45^{\circ}$ to $45^{\circ} 15^{\prime} \mathrm{N}$., long $114^{\circ}$ to $114^{\circ} 15^{\prime}$ W.) (in fig. 3 , entire area north of lat $45^{\circ}$ lies within the Leesburg $15^{\prime}$ quadrangle). These workers divided their subunit into an upper and a lower part, both of which here are reassigned to the Gunsight Formation (table 1). The upper part of their upper subunit was described as flat-laminated and hummocky crosslaminated arkosic quartzite. The lower part of their upper subunit was described as interbedded flat-laminated arkosic quartzite and micaceous siltite. My observations show fluvial deposits on the northwest, in the vicinity of Deep Creek Ridge (fig. 3), and a genetically associated sequence of hummocky beds, shoreface strata, and lenses of conglomerate to the southeast, in the vicinity of Lake Mountain. Each of these genetically associated units is described separately, then integrated into a 


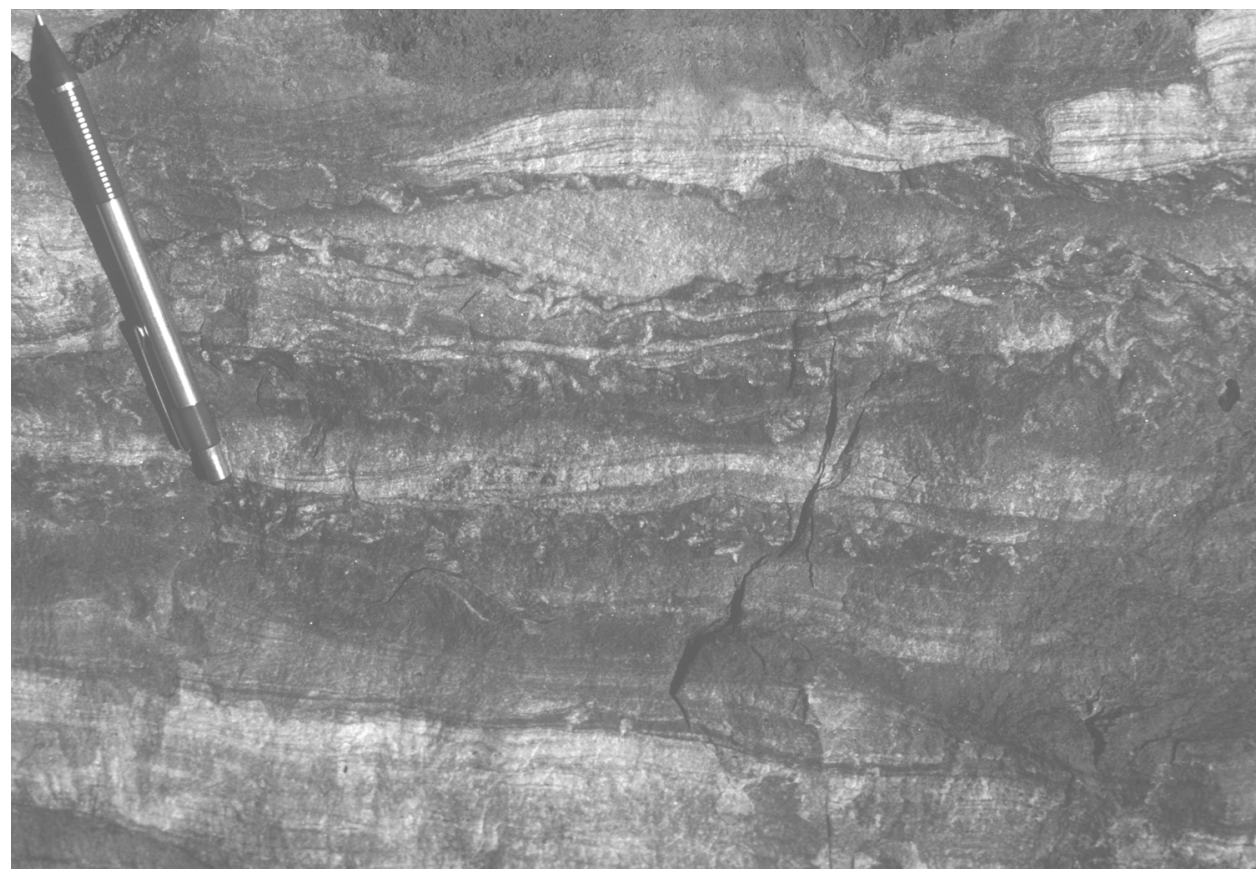

Figure 10. Dikelets associated with light-gray metasandstone bed cut by dark-gray siltite during soft-sediment deformation. Structures interpreted to reflect loading of sandstone bed onto watersaturated silt, causing flowage of silt and thin interbeds of light-gray fine-grained sandstone that formed dikelets. Deep Creek area of Salmon River Mountains. Pencil $13 \mathrm{~cm}$ long.

general model for deposition. The fluvial strata are described in a following section.

The hummocky crossbedded rocks and associated metasandstone contrast sharply with the dominantly fine siltite and banded black-and-white beds of the underlying banded siltite unit of the Apple Creek Formation. I follow Connor and Evans (1986) in assigning the hummocky and associated strata to the post-Apple Creek strata (that is, post "middle subunit of the Yellowjacket Formation" of their nomenclature). But because the hummocky strata are gradational with the banded siltite unit, I placed them in the lowermost part of the Gunsight Formation, in contrast to Connor and Evans' (1986) placement of them in the upper part. The following discussion of stratigraphic and structural relationships shows my reasoning.

\section{Stratigraphic Relationships}

\section{Hummocky Crossbedded Strata}

Hummocky crossbedded strata (fig. 11) are present in the vicinity of Lake Mountain (figs. 2, 3). Typical features of hummocky cross-stratification include the following: (1) crossbed sets display lower bounding surfaces that are erosional, commonly sloping at angles of less than $15^{\circ}$; (2) overlying laminae are parallel to set boundaries, or nearly so; (3) laminae above the erosional base systematically thicken laterally in a set, such that their traces on a vertical surface are fan-like; and (4) the directions of dip of erosional set boundaries are scattered (Harms and others, 1975; Cheel and Leckie, 1993). The beds, composed of an amalgamation of hummocks, typically are separated by 1-5 $\mathrm{mm}$ thick layers of dark-gray siltite. In a few places, siltite (metamudstone) lenses occur between beds. Currents have eroded the upper part of some hummocky beds. Ripples are fairly common features in the uppermost part of some beds. Stacked 1-3 cm thick sets of ripples were observed above one eroded hummocky bed. The upper part of each ripple set was eroded before deposition of 1-3 mm of dark-gray siltite, and the overlying ripple set. The ripples generally show transport to the northeast, but a few ripples show transport to the southwest. Pebble lags are present along the base of a few hummocky beds and along foreset laminae of other beds. These features have been reported within hummocky beds by McKie (1994).

The hummocky crossbedded strata are conformable and transitional with the upper strata of the underlying banded siltite unit of the Apple Creek Formation. The prominent soft-sediment load and slump structures of the upper strata of the banded siltite also occur in the lower strata of the hummocky crossbedded unit. This is illustrated in figure 12 where a small hummocky crossbed overlies a succession of slumped beds of finegrained metasandstone. The slumping, or at least most of it, took place before deposition of the overlying hummocky crossbedded metasandstone. Figure 13 shows a hummocky crossbedded metasandstone bed interpreted to have been deposited on a water-rich silt (now siltite) from which the water flowed and disrupted-pulled apart - the bed of metasandstone.

Two alternatives for the stratigraphic level of hummocky strata in the Gunsight Formation were considered. Because fluvial Gunsight strata grade upward and downward into marine strata, hummocky (marine) Gunsight strata might be expected in either the upper or lower parts of the Gunsight Formation. In the lower part of the hummocky sequence, turbidites and local slump structures are interbedded with the hummocky beds. The contact of hummocky crossbedded strata with the underlying turbidites of the banded siltite unit of the Apple Creek Formation 


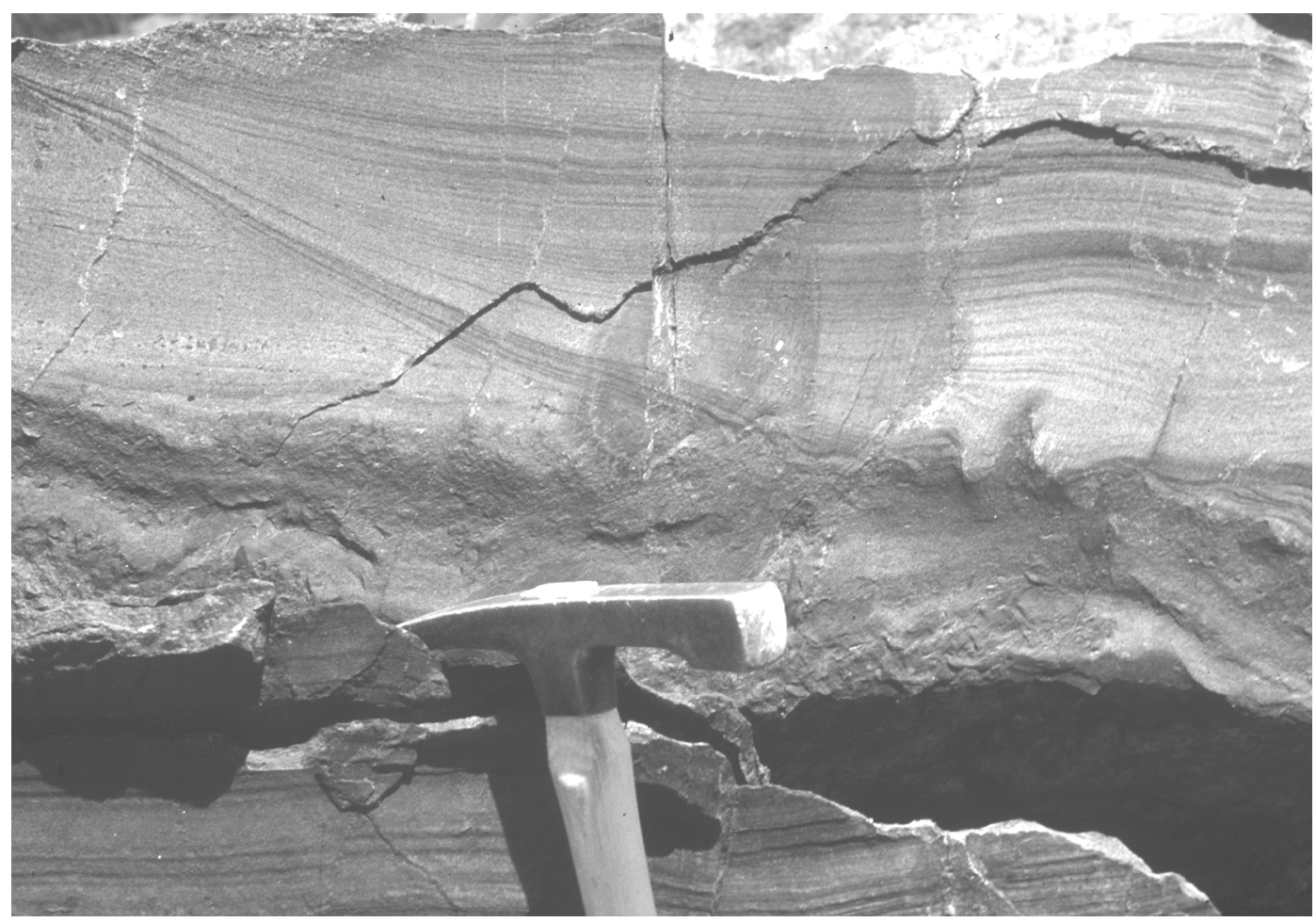

Figure 11. Hummocky crossbeds at Lake Mountain in Salmon River Mountains. Hammer head $20 \mathrm{~cm}$ long.

is gradational and conformable. This indicates that the hummocky strata occur in the lower part of the Gunsight Formation.

I know of no other occurrence of hummocky crossbedded strata in the Salmon River Mountains or Lemhi Range (or Beaverhead Mountains or Clearwater Mountains). The upper part of the Gunsight in the type section near Gunsight Peak in the Lemhi Range (fig. 1), and in the vicinity of Phelan Mountain 10 $\mathrm{km}$ directly north of Lake Mountain (fig. 3), is a medium- to coarse-grained quartzite to orthoquartzite sequence that contains trough crossbeds as much as $1 \mathrm{~m}$ across. I observed no hummocky beds in either area, however, and none were reported by McBean (1983) in the type section. In contrast, the hummocky and associated strata of the Lake Mountain area are not quartzite or orthoquartzite, but fine-grained arkosic metasandstone to coarse-grained siltite. In the western part of the Lemhi Range, in the Poison Peak area and in the type section near Gunsight Peak, fluvial strata occur downsection from the quartzite and orthoquartzite of the upper strata of the Gunsight. These stratigraphic and sedimentologic data argue against the occurrence of hummocky strata in the upper part of the Gunsight Formation.

\section{Shoreface Strata ${ }^{4}$}

North of Lake Mountain (fig. 3), coarse siltite to finegrained hummocky metasandstone beds give way upsection to

4 Definition of shoreface used here follows that of Walker (1992), wherein shoreface sediment is deposited above fair-weather wave base to high tide line. Hummocky crossbedded sediment is deposited below fair-weather wave base. (In contrast, some workers include hummocky crossbedded sediment in the lower shoreface, even though the sediment is deposited below normal wave base.)

\section{4}

Mesoproterozoic Lemhi Group, Central Idaho rocks of similar composition that lack hummocks. The strata are mainly composed of fairly clean quartz-feldspar metasandstone of uniformly fine grain size. Beds are 0.5-1 m thick. Many beds are characterized by planar lamination. Others display moderate to steeply dipping foreset laminae of megaripples (subaqueous dunes); some of the laminae dip to the northeast. Beds in some areas pinch and swell (are undulatory) for distances of 1-5 m. Dark-gray fine-grained siltite (metamudstone), in lenses $20-100 \mathrm{~cm}$ thick and as much as $1 \mathrm{~m}$ long, lie between metasandstone beds in a few places. Mud chips occur along crossbed laminae locally. Lenses of angular pebbly mudstones are present, but not common, within the metasandstone. Rare, local slumped beds of metasandstone show transport to the southwest. The shoreface strata contain interstratified amalgamated hummocky beds in a few places on and north of Lake Mountain, indicating intertonguing relationship of the two lithofacies. Some of the shoreface deposits may be reworked hummocky strata.

Intraformational Conglomerate

Intraformational conglomerate was reported at three localities in the Lake Mountain area by Connor and Evans (1986), and I observed a fourth outcrop about $2.5 \mathrm{~km}$ farther northeast (fig. 3). J.J. Connor (oral commun., 1987) described the conglomerates as channel-like deposits that contain angular and rounded clasts of metasandstone similar to that of the country rock, streaked-out mudstone clasts, and local flow-rolls (balland-pillow structures) (fig. 14) as much as $1 \mathrm{~m}$ across. The matrix of the conglomerates is dark-gray fine-grained siltite, 


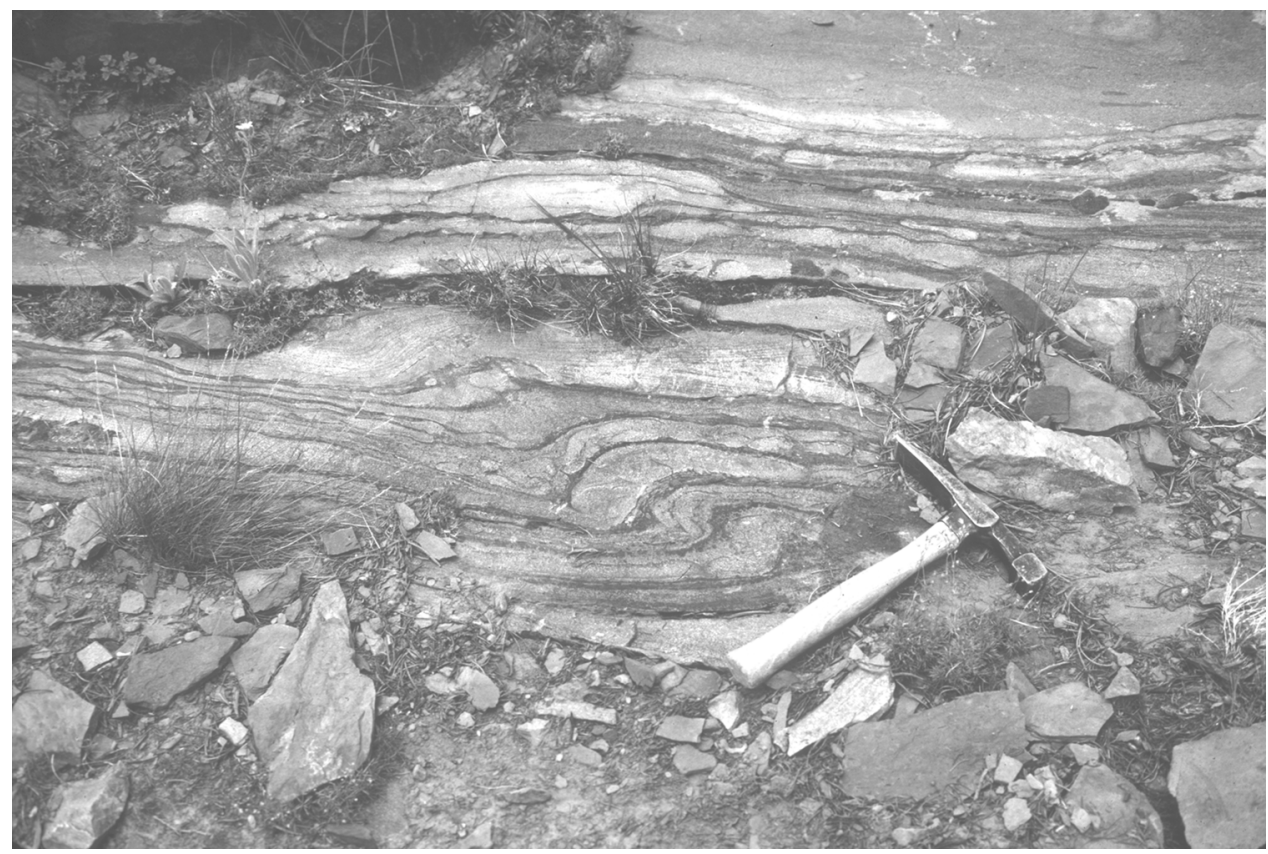

Figure 12. Slump structure overlain by non-slumped light-gray hummocky crossbedded metasandstone (bed just above point of hammer) and other metasandstone beds. Lower part of hummocky crossbedded metasandstone unit, Lake Mountain area of Salmon River Mountains. Hammer handle $22 \mathrm{~cm}$ long.

which is well cleaved. The northern occurrence contains fewer and smaller clasts, and more matrix, than the other outcrops. The deposits have a cross-sectional width of only $10-15 \mathrm{~m}$ and are $10-15 \mathrm{~m}$ thick. The conglomerate about $1.5 \mathrm{~km}$ south of Lake Mountain occurs within a weathered-in-place rubble pile of hummocky crossbedded strata. The three occurrences northeast of Lake Mountain form resistant outcrops isolated within covered areas. The nearest host rocks are not hummocky beds, but shoreface strata.

J.J. Connor (oral commun., 1987) considered a possible fluvial origin for the conglomerates, but he favored a marine setting because of the associated hummocky strata. I concur with his interpretation, but note that the three northern occurrences are associated with the shoreface deposits. The channel interpretation of Connor and Evans (1986) is appropriate because of the limited cross-sectional size and the fine siltite matrix of the deposits. The soft-sediment deformation structures attest to the contemporaneity of the channels and the host sediment. The conglomerates may be channel-bottom deposits, formed of poorly sorted clastics transported seaward during storms or during strong tidal action.

\section{Origin}

Localization of the hummocky and associated strata to the Lake Mountain area of the Salmon River Mountains must be due to local depositional parameters or to erosion that could have removed such deposits from elsewhere in the region. Hummocky crossbeds generally are interpreted as storm features that accumulated below fair-weather wave base (Harms and others, 1975; Walker and Plint, 1992; Cheel and Leckie, 1993). Preservation of the hummocky strata suggests this as an appropriate interpretation for the Lake Mountain area. Examination of the hummocky and associated strata was conducted in a reconnaissance manner to determine a plausible interpretation that accommodates the general features observed and a likely reason for generation and preservation of the strata. No attempt was made to work out details of the depositional environment.

Walker and Plint (1992) noted that most studies of storm deposits have been conducted on strata deposited in the Cretaceous Western Interior seaway of North America; a few studies are set elsewhere. In these settings, sand bodies that display hummocky crossbeds, and their commonly overlying swaley crossbedded strata are sheetlike, extend for many hundreds of kilometers along depositional strike, may prograde over $300 \mathrm{~km}$ seaward, and are wave dominated. (Swaley crossbeds are shallow swales - scours $-0.5-2 \mathrm{~m}$ wide that are filled with concaveupward laminae of sand. The infilling laminae conform to the shape of the swale, gradually flattening out upward.) No swaley crossbedded strata were observed in the Mesoproterozoic rocks of central Idaho. The Cretaceous strandline-generated sheetlike sandstone bodies reflect microtidal environments, which are wave dominated. Strand plains and long, narrow barrier islands are characteristic of such settings. Mesotidal settings also contain barrier islands, although they tend to be short and fairly wide, owing to interruption by frequent tidal channels and associated ebb- or flood-tidal deltas. The Lake Mountain area contains the only known occurrence of hummocky and associated strata in the Mesoproterozoic strata of central Idaho. No sheetlike sandstone bodies, interpreted to be strand-plain or barrier island deposits, are known to be present in the Gunsight Formation of the Lemhi Range or the Salmon River Mountains (or Beaverhead Mountains).

The abundance of the hummocky beds at Lake Mountain indicates that the area south of Lake Mountain represents the seaward part of the depositional environment, below normal wave base, otherwise the hummocky beds would not be

Correlation, Sedimentology, Structural Setting 


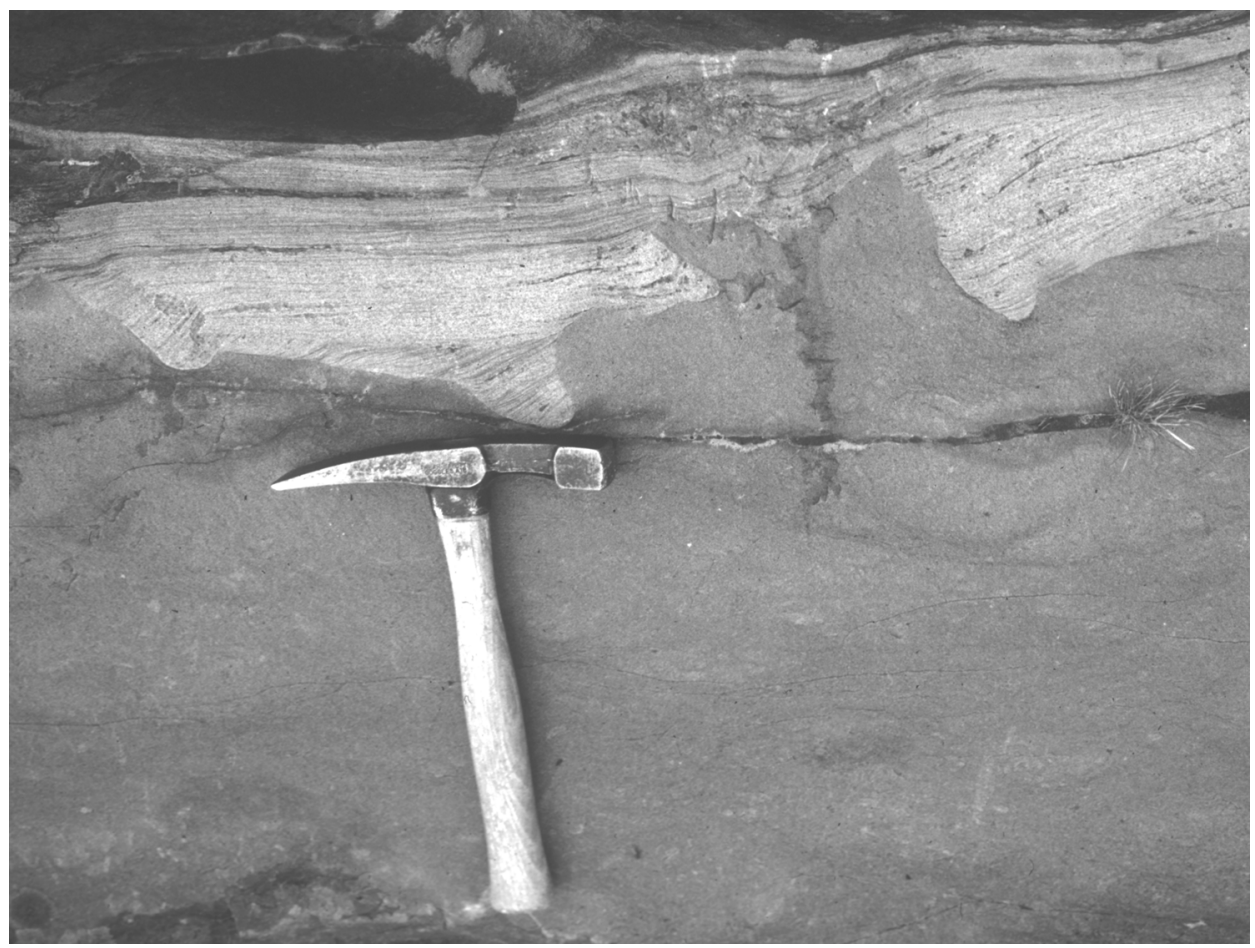

Figure 13. Light-gray hummocky crossbedded metasandstone bed deposited on dark-gray siltite, interpreted as water-saturated at time of deposition. Loading of sandstone onto water-saturated silt caused flowage of silt and disruption of sandstone. Lake Mountain area of Salmon River Mountains. Hammer handle $22 \mathrm{~cm}$ long.

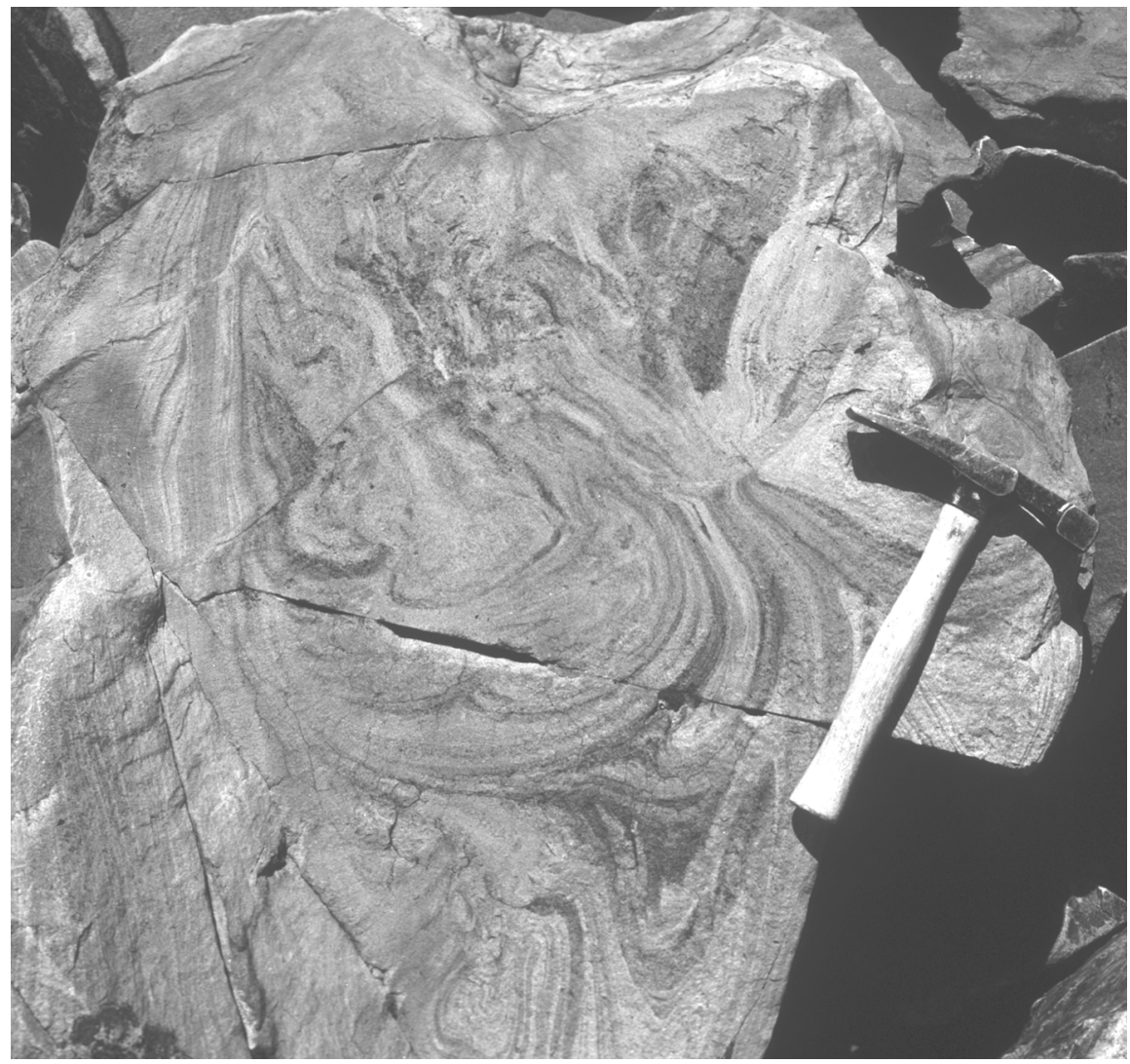

Figure 14. Flow-rolls in siltite, interpreted as channel deposit associated with the hummocky crossbedded metasandstone unit. Float block, Lake Mountain area of Salmon River Mountains. Hammer handle $22 \mathrm{~cm}$ long. 
preserved. Thus, the directly overlying strata could represent reworked hummocky beds. The small conglomerate-bearing channels only a few meters across that lie within the sequence may have served as conduits to transport fine sediment to offshore, deeper waters.

\section{Erosion Surface}

The stratigraphic sequence in the Lake Mountain area differs from that in the Deep Creek road area (figs. 3, 4). In the Lake Mountain area, the ascending stratigraphic sequence is turbidites - storm reworked deposits - hummocky beds - shoreface deposits - erosion surface(?) - fluvial rocks. In the Deep Creek road area, the ascending sequence is turbidites - storm-reworked deposits - erosion surface - fluvial rocks; no hummocky beds or shoreface strata are present.

In a complete regressive sequence, shoreface and beach or tidal-flat strata overlie hummocky strata in depositional transition into delta plain fluvial strata. The shoreface beds north of Lake Mountain are interpreted as erosionally truncated, a common occurrence within stratigraphic sections (Miall, 1996, p. 463), wherein upper shoreface and tidal-flat strata are eroded and fluvial rocks of the delta plain lie directly on lower shoreface or offshore strata.

Along the Deep Creek road (fig. 3), fluvial strata lie on the storm-reworked deposits of the banded siltite unit of the Apple Creek Formation. The actual contact is concealed within a 25m-thick covered interval. No float of hummocky, shoreface, or tidal flat strata was observed in the interval. Further, I found no evidence for a fault in the covered interval. Although a concealed fault within this interval cannot be excluded, such a fault would have to be nearly horizontal or dip to the north at a low angle, in contrast to the steeply dipping folds and faults of the area. Upstream (southeast) from the southeasternmost hairpin turn of the Deep Creek road (fig. 3) to Pepper Creek, and then north to the Poison Creek thrust fault, sparse outcrops are of shoreface and fluvial strata. These observations suggest that an erosion surface may lie between the shoreface and fluvial rocks north and northwest of Lake Mountain, and the erosion surface cuts downsection westward to the Deep Creek area, where fluvial rocks overlie upper strata of the banded siltite unit of the Apple Creek.

\section{Fluvial Strata}

Fluvial strata in the eastern part of the Salmon River Mountains were observed in roadcuts along the Deep Creek road, uphill from the southeasternmost hairpin turn (fig. 3). Low- angle crossbedding is common. The beds commonly range from 20 to $50 \mathrm{~cm}$ thick and are coarse-grained siltite to fine-grained metasandstone. Thicker beds typically are amalgamations of thinner strata and extend farther laterally than the thinner beds. Mudchips, pebbles, and gravel are absent. Small channels 1-3 m wide in cross section were observed locally, with nested, upward-decreasing trough crossbeds. However, most beds do not define channels; they taper out laterally, replaced by other beds, forming complex sheets of lenticular beds. Some outcrops clearly show inclined surfaces of deposition and erosion, interpreted as lateral accretion deposits, whereas other outcrops do not reveal surfaces that cut downward. This reflects different orientations of section faces, or the faces could reflect different depositional environments within the varied depositional settings. The exposed rocks contain a low percentage (estimated at 10-15 percent) of fine-grained siltite (metamudstone) a few centimeters thick between beds of metasandstone. The fine-grained units probably are at least a few hundred meters in extent. Other fine-grained units are discontinuous, and sandstones rest directly on other sandstone. The recessive weathering of these fine-grained strata makes the metasandstone beds stand out.

The strata are interpreted as braided or sheet-braided deposits, laid down in a fluvial system dominated by sand to coarse silt. They correspond to the distal, sheetflood, sand-bed river model of Miall (1996, p. 240-241), and display bed characteristics similar to those pictured by Miall (1985, his model 11), Smith (1970), Cotter (1978), and the medial to distal distributary alluvial fan deposits of Kelly and Olsen (1993). Miall (1994, p. 155) interpreted such strata as follows: "The lateral amalgamation of many bars of different type, and the absence of clearly defined channel margins, suggests the dominance of a multiple-channel fluvial style, in which sinuosities were low to moderate, and both lateral and downstream accretion were common. Most bars and bar complexes were probably mid-channel in origin rather than bank-attached." The low percentage of metamudstone (fine siltite) argues for a lack of overbank deposits, or at least the lack of preservation of such deposits.

\section{Map Pattern}

The map pattern displayed by the lower strata of the Gunsight Formation and that of the underlying banded siltite unit of the Apple Creek Formation are closely related. Connor (1990, p. 9) stated that the banded siltite unit (his "middle subunit of the Yellowjacket Formation") thinned rapidly to the east in the Salmon River Mountains, probably to extinction. He attributed the thinning to intertonguing at both the top and the bottom of the unit, with loss of characteristic strata eastward. These relationships are shown on the maps of Connor and Evans (1986) and Connor (1990, fig. 2A). My mapping (fig. 2) also indicates that the banded siltite unit thins eastward in the Salmon River Mountains.

The abrupt end to the banded siltite, hummocky strata, and shoreface metasandstone east of Lake Mountain is attributed to erosion. From south to north in the Degan Mountain to Deep Creek area of the Salmon River Mountains (figs. 2, 3), stratigraphic units gradually appear upsection above the coarse siltite unit. In the vicinity of the Twin Peaks mine and Degan Mountain, only the coarse siltite unit is present (fig. 3). The banded siltite unit first appears about $3 \mathrm{~km}$ north of Degan Mountain. The southernmost exposure of basal strata of the Gunsight Formation occurs about $3 \mathrm{~km}$ farther north, south of Lake Mountain. Both the banded siltite unit and the overlying strata of the Gunsight Formation dip moderately northward in the area; thus, the outcrops of the two units along the ridge crest from Degan 
Mountain to Lake Mountain display the southernmost outcrops of each unit.

\section{Structure}

Mapping in the east-central part of the Salmon River Mountains was conducted to determine the general structural style of the area, in order to resolve stratigraphic and sedimentologic problems, to confine possible interpretations of the stratigraphy, and to integrate the local stratigraphy into the regional patterns. These goals were accomplished by detailed mapping in critical areas, with some reconnaissance through the more generally mapped terrain shown on the maps of Shockey (1957), Connor and Evans (1986), and Evans (1981).

\section{Poison Creek Thrust Fault}

The Poison Creek thrust fault, one of the major thrust faults of east-central Idaho, trends northwest across the western part of the Lemhi Range and into the eastern part of the Salmon River Mountains. The fault generally dips about $35^{\circ} \mathrm{SW}$. In the Lemhi Range, the thrust fault placed hangingwall strata of the Apple Creek Formation over footwall lower Paleozoic rocks and underlying Mesoproterozoic strata of the Swauger and Gunsight Formations. Hangingwall rocks are part of the Poison Creek thrust sheet, and footwall rocks are part of the McDevitt Creek thrust sheet (fig. 2, inset map) (Tysdal, 2002). Recognition and mapping of the Poison Creek thrust fault across the part of the study area that lies in the Salmon River Mountains (figs. 1-3) proved critical to determining that rock units there are juxtaposed on different thrust sheets just as they are in the Lemhi Range. Some characteristics of the fault are described here because structure (1) bears importantly on the thickness of the Gunsight Formation in the area and (2) displays continuity of regional structural and stratigraphic patterns.

The Poison Creek thrust fault was first delineated across the western part of the Lemhi Range by Tysdal (1996a) and Tysdal and Moye (1996). K.V. Evans, Falma Moye, and R.F. Hardyman (unpub. data, 1996) extended the fault into the eastern part of the Salmon River Mountains, vicinity of the Twin Peaks mine (fig.

2). Evans and associates recognized that an isolated, unnamed fault segment originally mapped near the Twin Peaks mine by Ekren (1988), and along which Apple Creek strata are juxtaposed against Ordovician carbonate rocks, is a short segment of the Poison Creek thrust. The fault is concealed by volcanic rocks of the Eocene Challis Volcanic Group north of the mine.

The map of Ekren (1988) and the mapping of K.V. Evans, Falma Moye, and R.F. Hardyman (unpub. data, 1996) show the fault segment near the Twin Peaks mine to trend only a few degrees west of north and to dip steeply to the west. North from the mine area, I interpret the fault to extend for about $8 \mathrm{~km}$ beneath volcanic rocks of the Eocene Challis Volcanic Group and to connect with the northwest-trending Leesburg fault that Shockey (1957, pl. 1) mapped northwest from near the South Fork of Williams Creek to west of Phelan Mountain (fig. 3). (I consider the Leesburg fault to be a segment of the Poison Creek fault; the Poison Creek name is applied to the fault to maintain continuity for the regional structure.) The northerly trending segment of the Poison Creek thrust fault coincides with a steepening of the fault dip to $60^{\circ}-65^{\circ} \mathrm{W}$. and a downcutting across footwall Paleozoic rocks. The northerly trend and the steep dip of the Poison Creek thrust fault are here interpreted as reflecting an oblique footwall ramp, which strikes at an angle to the general northeast transport direction of the hangingwall of the thrust fault.

The northwest-trending Leesburg segment of the Poison Creek thrust fault (northwest from near the South Fork of Williams Creek to west of Phelan Mountain, fig. 3), was interpreted by Shockey (1957, pl. 2) as a reverse fault, up on the southwest, with a dip about $70^{\circ} \mathrm{SW}$. However, intensely developed cleavage of the juxtaposed hangingwall and footwall rocks in the South Fork Williams Creek area indicate a southwest dip of $30^{\circ}-40^{\circ}$ for the fault segment. Thin sections of upper Gunsight strata of the footwall reveal protomylonite textures in some places. In contrast, Connor and Evans (1986) had reinterpreted the Leesburg fault of Shockey (1957) as the southwest limit of a klippe, overthrust from the southwest, and showed its dip inclined to the northeast at a low angle. They showed the northeast edge of the klippe to be a low-angle, southwest-dipping fault delimiting the northeast edge of the Swauger Formation east of Phelan Mountain (fig. 3). My observations show this Swauger contact to be depositional. The Leesburg name was not used for the fault by Connor and Evans (1986).

Shockey (1957, pl. 1) showed the northwest-trending part of the Leesburg fault segment to be discontinuously exposed, with one exposed part southeast of Phelan Mountain (figs. 2, 3) and the other near long $114^{\circ} 15^{\prime} \mathrm{W}$., near the north edge of the area of figure 2. Connor and Evans (1986) mapped the fault segment in the same position, but showed the Mesoproterozoic granite pluton in the area near long $114^{\circ} 15^{\prime} \mathrm{W}$. (fig. 2) in fault contact, dipping northeast at a low angle, with a klippe. Near Napias Creek, I observed intensely cleaved Proterozoic granite (fig. 3) in contact with Gunsight strata and interpret the contact as a fault. The cleavage dips southwestward at a moderate angle, and I interpret the fault to have the same inclination.

\section{Juxtaposed Strata}

Hangingwall strata in the western part of the Lemhi Range show the coarse siltite unit of the Apple Creek Formation to be the youngest Proterozoic unit preserved in the range. In the east-central part of the Salmon River Mountains, in the Twin Peaks mine to Degan Mountain area (fig. 2), only rocks of the upper part of the coarse siltite unit are present. Younger strata gradually appear northward from Degan Mountain. About $3 \mathrm{~km}$ north of Degan Mountain, the banded siltite unit of the Apple Creek crops out. Farther north, about $3 \mathrm{~km}$ south of Lake Mountain, the hummocky beds appear. Both the banded siltite unit and the overlying hummocky beds of the Gunsight Formation dip moderately northward; thus, the outcrops of the two units along the ridge crest from Degan Mountain to Lake Mountain display the southernmost outcrops of each unit. North of 
Lake Mountain, the hummocky beds give way to shoreface clastics, then fluvial strata. In the area of the South Fork Williams Creek (fig. 3), where the Poison Creek fault changes from a northerly to a northwest trend, shoreface strata of the lower Gunsight are thrust over quartzite of the uppermost part of the Gunsight.

Footwall strata of the Poison Creek thrust in the western part of the Lemhi Range show the uppermost Gunsight rocks and the conformably overlying Swauger Formation to constitute the youngest Mesoproterozoic rocks. (These strata lie north of the Poison Creek thrust fault, north of lat $44^{\circ} 52^{\prime} 30^{\prime \prime} \mathrm{N}$. and near long $113^{\circ} 52^{\prime} 30^{\prime \prime} \mathrm{W}$., and are not shown in fig. 2.) The same footwall sequence is present in the Salmon River Mountains, where the Swauger and the directly underlying uppermost Gunsight rocks of the Phelan Mountain-Williams Creek area occur (fig. 3). This same structural and stratigraphic setting must exist farther northwest, on both sides of the north-south concealed fault at long $114^{\circ} 07^{\prime} 30^{\prime \prime} \mathrm{W}$., because the Swauger and upper Gunsight strata west of the concealed fault appear to be an extension of the strata of the Phelan Mountain-Williams Creek area (fig. 3). Hence, west of the concealed fault, the Poison Creek thrust fault should lie southwest of the Swauger Formation. The thrust has significant displacement - hence my agreement with Connor and Evans (1986) in interpreting a fault to delimit the northeastern boundary of the Proterozoic granite near long $114^{\circ} 15^{\prime} \mathrm{W}$. (fig. 2).

\section{Tectonic Breccia}

Tectonic breccia was observed by me in four widely separated, isolated outcrops near the Poison Creek thrust fault. The isolated outcrops are dispersed from near the South Fork Williams Creek to midway along the Deep Creek Ridge (fig. 3). The zone of brecciation trends toward the junction area of the Deep Creek and Moccasin Creek roads (fig. 3), where it is concealed by glacial deposits. The breccias are composed of angular clasts of metasandstone tightly cemented within a chloritized matrix of the same composition. In some places, breccia fragments are composed of mylonitic rock; the mylonite is oriented differently in adjacent clasts, indicating reorientation of the mylonite fabric during the brecciation process. The breccia is interpreted as a product of extensional deformation. The breccias define the general location of a fault, but the limited outcrops do not permit determination of a precise location. The extension took place subsequent to compressional deformation that produced the Poison Creek thrust fault and likely reflects normal displacement within the zone of the Poison Creek thrust. The magnitude of the extension is uncertain, however.

\section{Thickness of Gunsight Formation}

The Gunsight Formation in the Salmon River Mountains area shown in figure 3 is too thin for a full stratigraphic section to be present. That this is likely true can be shown by a comparison with the Gunsight thickness in the Lemhi Range.
Northwest from the South Fork of Williams Creek, extension along the trend of the Poison Creek fault subsequent to compressional thrusting accounts for some of the thinned section of the Gunsight, yet the same pattern of hangingwall/footwall relationships that exists in the western part of the Lemhi Range is maintained in the Salmon River Mountains. Compressional folding and variable dip of the strata also indicate that a full section of the Gunsight Formation cannot be present in the area of figure 3, as explained in the following paragraphs.

The Gunsight Formation at the type section in the Lemhi Range is greater than $1,725 \pm \mathrm{m}$ thick (measured section of McBean, 1983), and as McBean stated, is incomplete owing to a normal fault at the top of the section. Although the lower part of the McBean (1983) section included about $450 \mathrm{~m}$ of the Apple Creek Formation, a normal fault may omit more than this thickness of Gunsight strata from the basal part of the Gunsight measured section (Tysdal, unpub. data, 1995). In the Poison Peak area of the northwestern part of the Lemhi Range (fig. 1), the Gunsight is approximately as thick as the type section, based on the mapping work of G.W. Winkler (unpub. data, 1996).

In the vicinity of Lake Mountain, in the Salmon River Mountains, thicknesses determined from map patterns show that the rocks between the upper strata of the banded siltite unit southwest of the mountain and the trace of the Poison Creek thrust fault northeast of it are much less than that of the Gunsight in the type area and on the footwall of the Poison Creek thrust fault in the Lemhi Range. Northeast of the Lake Mountain thrust fault (figs. 2, 3), which is believed to have only minor displacement, dips of the shoreface rocks that overlie the hummocky beds generally display low-angle northwesterly dips. Steep dips are associated with tight folds in the vicinity of the Poison Creek thrust, however. The extensive area of low dips between the top of the banded siltite unit and the Poison Creek thrust fault testifies to a much too thin sequence of Gunsight strata for the entire formation to be present.

In the Deep Creek Ridge area (fig. 3), thickness determinations also show that the Gunsight is too thin to accommodate the entire formation. Assuming a vertical dip, the maximum thickness of the Gunsight in the study area would be about 2,100 m, measuring from the top of the banded siltite unit of the Apple Creek Formation along the Deep Creek road to the inferred location of the Poison Creek thrust fault in the vicinity of Deep Creek Ridge. This thickness is similar to that in the type area and in the northwestern part of the Lemhi Range. However, the dips of the Gunsight in the Deep Creek Ridge area are not vertical. Dips generally are moderate, the area contains locally tight folding, and minor thrust faults cause repetition of strata. Taken together, these data indicate that the Gunsight is less than the maximum possible thickness, and probably less than half its actual thickness in this area.

Other Implications of Existence of Poison Creek Thrust Sheet in Salmon River Mountains

Recognition that the Poison Creek thrust fault extends northwestward from the Lemhi Range well into the Salmon River Mountains has several implications, including the 
following: (1) Paleozoic and Mesoproterozoic plutons in the northwestern part of the map areas shown in figures 2 and 3 are delimited on the northeast by the Poison Creek thrust fault. The plutons are part of the Poison Creek thrust sheet and must have been transported northeast during thrusting and, therefore, must be rootless. (2) The Poison Creek thrust fault displaced older rocks over younger rocks, the usual situation. The plutons of the Poison Creek thrust sheet, therefore, should represent a deeper level of pluton emplacement than do similar plutons present in the footwall McDevitt Creek rocks northeast of the thrust fault, north of the map area. (3) The stratabound cobalt-bearing mineralized rocks of the Blackbird mining district are part of the Poison Creek thrust sheet and are rootless. (4) The banded siltite unit that hosts the mineralized rocks of the Blackbird district in the Salmon River Mountains is almost entirely absent from the Lemhi Range. It occurs only in a small fault sliver of the Poison Creek thrust fault in the westernmost part of the range. The banded siltite unit probably existed within the Poison Creek thrust sheet in the Lemhi Range but has been eroded from exposed rocks. The Blackbird type of mineralization confined to the banded siltite unit is, if present in the western part of the Lemhi Range, concealed beneath the Gunsight Formation.

\section{Conclusions}

Stratigraphic units of the Mesoproterozoic Apple Creek, Gunsight, and Swauger Formations present in the Lemhi Range correlate with stratigraphic units in the Salmon River Mountains that previously were assigned to the Yellowjacket and Big Creek Formations. The "middle subunit of the Yellowjacket Formation" (Connor and Evans, 1986) in the Salmon River Mountains is renamed the banded siltite unit and placed in the Apple Creek Formation. Strata of the "upper subunit of the Yellowjacket Formation" are correlated with the Gunsight Formation of the Lemhi Range and renamed accordingly. Strata previously interpreted as the Mesoproterozoic Big Creek Formation, on a thrustfloored klippe in the eastern part of the Salmon River Mountains, are determined to lie depositionally above the Gunsight Formation and are assigned to the Swauger Formation.

The banded siltite unit of the Apple Creek Formation lies conformably above the coarse siltite unit of the formation, which previously was correlated between the Lemhi Range and the Salmon River Mountains. The banded siltite unit is confined almost entirely to the Salmon River Mountains. From southwest to northeast in the Salmon River Mountains, the stratigraphic succession reflects a marine offshore to fluvial onshore sequence. The coarse siltite unit and most of the overlying banded siltite unit of the Apple Creek Formation are interpreted as marine turbidites that were deposited offshore, in a slope or fan setting. Upper strata of the banded siltite unit are interpreted as turbidites that were reworked by currents, probably related to storms. Basal strata of the Gunsight Formation are hummocky crossbedded metasandstone interpreted as storm deposits. Preserved hummocky beds must have been deposited below storm wave-base. Gradationally overlying beds, with some interbedded hummocky crossbedded strata, are termed shoreface strata and are interpreted as shallow marine. Younger strata of the lower part of the Gunsight Formation display characteristics of fluvial rocks and likely were deposited in a delta plain.

Continuity of the stratigraphic succession from the Lemhi Range to the Salmon River Mountains, as well as subdivision of the units within the Salmon River Mountains, was accomplished in part through geologic mapping in the Salmon River Mountains to determine continuity of structural features there with those of the Lemhi Range. The Poison Creek thrust fault, and the Poison Creek thrust sheet that forms the hangingwall of the thrust fault, extend into the eastern part of the Salmon River Mountains. The Apple Creek Formation and overlying basal strata of the Gunsight Formation form part of the hangingwall Poison Creek thrust sheet in the Salmon River Mountains. Mineral deposits of the Blackbird mining district, as well as Mesoproterozoic granite (fig. 3), also form part of the Poison Creek thrust sheet and were displaced to the northeast during orogenic activity. Rocks exposed in the footwall of the thrust fault in the Salmon River Mountains are upper strata of the Gunsight Formation and the conformably overlying Swauger Formation.

\section{References Cited}

Bouma, A.H., 1962, Sedimentology of some flysch deposits-A graphic approach to facies interpretation: Amsterdam, Elsevier, 168 p.

Cheel, R.J., and Leckie, D.A., 1993, Hummocky cross-stratifications, in Wright, V.P., ed., Sedimentology Review/1: London, Blackwell, p. 103-122.

Connor, J.J., 1990, Geochemical stratigraphy of the Yellowjacket Formation (Middle Proterozoic) in the area of the Idaho cobalt belt, Lemhi County Idaho, with analytical contributions from A.J. Bartel, E.L. Brandt, P.H. Briggs, S. Danahey, D. Fey, D.B. Hatfield, M. Malcolm, V. Merritt, G. Riddle, S. Roof, K. Stewart, J. Storey, J.E. Taggert, and R.B. Vaughn; Part A-Discussion; Part B-Geochemical data: U.S. Geological Survey Open-File Report 90-0234, 30 p.

Connor, J.J., 1991, Some geochemical features of the Blackbird and Jackass zones of the Yellowjacket Formation (Middle Proterozoic) in east-central Idaho, with analytical contributions from A.J. Bartel, P.H. Briggs, R.R. Carlson, J.G. Crock, B.H. Roushey, C.S.E. Papp, D.F. Siems, J.E. Taggert, Jr., and E.P. Welsch; Part A-Discussion (paper copy): U.S. Geological Survey Open-File Report 91-259-A, 25 p.

Connor, J.J., and Evans, K.V., 1986, Geologic map of the Leesburg quadrangle, Idaho: U.S. Geological Survey Miscellaneous Field Studies Map MF-1880, scale 1:62,500.

Cotter, Edward, 1978, The evolution of fluvial style, with special reference to the central Appalachian Paleozoic, in Miall, A.D., ed., Fluvial sedimentology: Canadian Society of Petroleum Geologists Memoir 5, p. 361-383.

Ekren, E.B., 1988, Stratigraphic and structural relations of the Hoodoo Quartzite and Yellowjacket Formation of Middle Proterozoic age from Hoodoo Creek eastward to Mount Taylor, central Idaho: U.S. Geological Survey Bulletin 1570, 17 p. 
Evans, K.V., 1981, Geology and geochronology of the eastern Salmon River Mountains, Idaho, and implication for regional Precambrian tectonics: University Park, Pa., The Pennsylvania State University Ph. D. dissertation, $222 \mathrm{p}$.

Evans, K.V., 1999, The Yellowjacket Formation of east-central Idaho, in Berg, R.B., ed., Proceedings-Belt Symposium III: Montana Bureau of Mines and Geology Special Publication 112, p. 17-30.

Evans, K.V., and Connor, J.J., 1993, Geologic map of the Blackbird Mountain 15-minute quadrangle, Lemhi County, Idaho: U.S. Geological Survey Miscellaneous Field Studies Map MF-2234, scale $1: 62,500$.

Hahn, G.A., and Hughes, G.J., Jr., 1984, Sedimentation, tectonism, and associated magmatism of the Yellowjacket Formation in the Idaho cobalt belt, Lemhi County, Idaho, in Hobbs, S.W., ed., The Belt: Montana Bureau of Mines and Geology Special Publication 90, p. 65-67.

Harms, J.C., Southard, J.B., Spearing, D.R., and Walker, R.G., 1975, Depositional environments as interpreted from primary sedimentary structures and stratification sequences: Society of Economic Paleontologists and Mineralogists Short Course Notes 2, 161 p.

Hiscott, R.N., Hall, F.R., and Pirmez, Carlos, 1997, Turbidity-current overspill from the Amazon channel-Texture of the silt/sand load, paleoflow from anisotropy of magnetic susceptibility and implications for flow processes, in Flood, R.D., Piper, D.J.W., and Peterson, L.S., eds., Proceedings of the 0 cean Drilling Program, Scientific Results: College Station, Texas, Texas A \& M University, v. 155, p. 53-78.

Hughes, G.J., Jr., 1983, Basinal setting of the Idaho Cobalt belt, Blackbird mining district, Lemhi County, Idaho, in Proceedings of the Denver Region Exploration Geologists Society Symposium, the genesis of Rocky Mountain ore deposits-Changes with time and tectonics: Denver Region Exploration Geologists Society, Denver, Colo., p. 2127.

Kelly, S.B., and Olsen, Henrik, 1993, Terminal fans-A review with reference to Devonian examples: Sedimentary Geology, v. 85, p. 339-374.

McBean, A.J., II, 1983, The Proterozoic Gunsight Formation, Idaho-Montana; stratigraphy, sedimentology and paleotectonic setting: University Park, Pa., The Pennsylvania State University M.S. thesis, 235 p.

McKie, Thomas, 1994, Geostrophic versus friction-dominated storm flow-Paleocurrent evidence from the Late Permian Brotherton Formation, England: Sedimentary Geology, v. 93, p. 73-84.

Miall, A.D., 1985, Sedimentation on an early Proterozoic continental margin under glacial influence-The Gowganda Formation (Huronian), Elliott Lake, Ontario, Canada: Sedimentology, v. 32, p. 763-788.

Miall, A.D., 1994, Reconstructing fluvial macroform architecture from two-dimensional outcrops-Examples from the Castlegate Sandstone, Book Cliffs, Utah: Journal of Sedimentary Research, v. B64, p. 146-158.

Miall, A.D., 1996, The geology of fluvial deposits-Sedimentary facies, basin analysis, and petroleum geology: New York, Springer-Verlag, $582 \mathrm{p}$.

Nash, J.T., 1989, Geology and geochemistry of synsedimentary cobaltiferous-pyrite deposits, Iron Creek, Lemhi County, Idaho: U.S. Geological Survey Bulletin 1882, 33 p.

Nash, J.T., and Connor, J.J., 1993, Iron and chlorine as guides to stratiform Cu-Co-Au deposits, Idaho cobalt belt, U.S.A.: Mineralium Deposita, v. 28, p. 99-106.
Nash, J.T., and Hahn, G.A., 1989, Stratabound Co-Cu deposits and mafic volcaniclastic rocks of the Blackbird mining district, Lemhi County, Idaho, in Boyle, R.W., Brown, A.C., Jefferson, C.W., Howett, E.C., and Kirkham, R.V., eds., Sediment-hosted stratiform copper deposits: Geological Association of Canada Special Paper 36, p. 339-356.

North American Commission on Stratigraphic Nomenclature, 1983, North American stratigraphic code: American Association of Petroleum Geologists Bulletin, v. 67, p. 841-875.

Plumb, K.A., 1991, New Precambrian time scale: Episodes, v. 14, no. 2, p. 139-140.

Ross, C.P, 1934, Geology and ore deposits of the Casto quadrangle, Idaho: U.S. Geological Survey Bulletin 854, $135 \mathrm{p}$.

Ruppel, E.T., 1975, Precambrian Y sedimentary rocks in east-central Idaho: U.S. Geological Survey Professional Paper 889-A, 23 p.

Shanmugam, G., 1997, Reinterpretation of depositional processes in a classic flysch sequence (Pennsylvanian Jackfork Group), Ouachita Mountains, Arkansas and Oklahoma-Reply: American Association of Petroleum Geologists Bulletin, v. 81, p. 476-491.

Shanmugam, G., Spalding, T.D., and Rofheart, D.H., 1993, Process sedimentology and reservoir quality of deep-marine bottom-current reworked sands (sandy contourites)—An example from the Gulf of Mexico: American Association of Petroleum Geologists Bulletin, v. 77, p. 1241-1259.

Shockey, P.N., 1957, Reconnaissance geology of the Leesburg quadrangle, Lemhi County, Idaho: Idaho Bureau of Mines and Geology Pamphlet 113, $42 \mathrm{p}$.

Smith, N.D., 1970, The braided stream depositional environment-Comparison of the Platte River with some Silurian clastic rocks, northcentral Appalachians: Geological Society of America Bulletin, v. 81, p. 2993-3014.

Sobel, L.S., 1982, Sedimentology of the Blackbird mining district, Lemhi County, Idaho: Cincinnati, Ohio, University of Cincinnati M.S. thesis, $235 \mathrm{p}$.

Stacey, M.W., and Bowen, A.J., 1988, The vertical structure of density and turbidity currents-Theory and observation: Journal of Geophysical Research, v. 93, p. 3528-3542.

Stow, D.A.V., and Shanmugam, G., 1980, Sequence of structures in finegrained turbidites-Comparison of recent deep-sea and ancient flysch sediments: Sedimentary Geology, v. 25, p. 23-42.

Stow, D.A.V., Faugeres, Jean-Claude, Adriano, Viana, and Gonthier, Elaine, 1998, Fossil contourites-A critical review: Sedimentary Geology, v. 115, p. 3-31.

Tysdal, R.G., 1996a, Geologic map of adjacent parts of the Hayden Creek and Mogg Mountain quadrangles, Lemhi County, Idaho: U.S. Geological Survey Miscellaneous Investigations Series Map I-2563, scale 1:24,000.

Tysdal, R.G., 1996b, Geologic map of the Lem Peak quadrangle, Lemhi County, Idaho: U.S. Geological Survey Geologic Quadrangle Map G0-1777, scale 1:24,000.

Tysdal, R.G., 1996c, Geologic map of part of May Mountain quadrangle, Lemhi County, Idaho: U.S. Geological Survey Open-File Report 96537, scale 1:24,000.

Tysdal, R.G., 2000a, Revision of Middle Proterozoic Yellowjacket Formation, central Idaho: U.S. Geological Survey Professional Paper 1601-A, $14 \mathrm{p}$. 
Tysdal, R.G., 2000b, Stratigraphy and depositional environments of Middle Proterozoic rocks in northern part of Lemhi Range, Lemhi County, Idaho: U.S. Geological Survey Professional Paper 1600, 40 p.

Tysdal, R.G., 2002, Structural geology of western part of Lemhi Range, eastcentral Idaho: U.S. Geological Survey Professional Paper 1659, 33 p.

Tysdal, R.G., and Desborough, G.A., 1997, Scapolitic metaevaporite and carbonate rocks of Proterozoic Yellowjacket Formation, Moyer Creek, Salmon River Mountains, central Idaho: U.S. Geological Survey Open-File Report 97-268, 26 p.

Tysdal, R.G., and Moye, Falma, 1996, Geologic map of the Allison Creek quadrangle, Lemhi County, Idaho: U.S. Geological Survey Geologic Quadrangle Map G0-1778, scale 1:24,000.
Walker, R.G., 1992, Turbidites and submarine fans, in Walker, R.G., and James, N.P., eds., Facies models-Response to sea level change: Geological Association of Canada, p. 239-263.

Walker, R.G., and Plint, A.G., 1992, Wave- and storm-dominated shallow marine systems, in Walker, R.G., and James, N.P., eds., Facies models-Response to sea level change: Geological Association of Canada, p. 219-238.

Winston, D.W., Link, K.P., and Hathaway, Nate, 1999, The Yellowjacket is not the Prichard and other heresies-Belt Supergroup correlations, structure and paleogeography, east-central Idaho, in Hughes, S.S., and Thackray, G.D., eds., Guidebook to the geology of eastern Idaho: Pocatello, Idaho, Idaho Museum of Natural History, p. 3-20. 


\section{Chemical Composition and Provenance of the Mesoproterozoic Big Creek, Apple Creek, and Gunsight Formations, Lemhi Group, Central Idaho}

By David A. Lindsey, Russell G. Tysdal, and Joseph E. Taggart, Jr.

Chapter B of

Correlation, Sedimentology, Structural Setting, Chemical Composition, and Provenance of Selected Formations in Mesoproterozoic Lemhi Group, Central Idaho

By Russell G. Tysdal, David A. Lindsey, and Joseph E. Taggart, Jr.

U.S. Geological Survey Professional Paper 1668-B

U.S. Department of the Interior

U.S. Geological Survey 


\section{Contents}

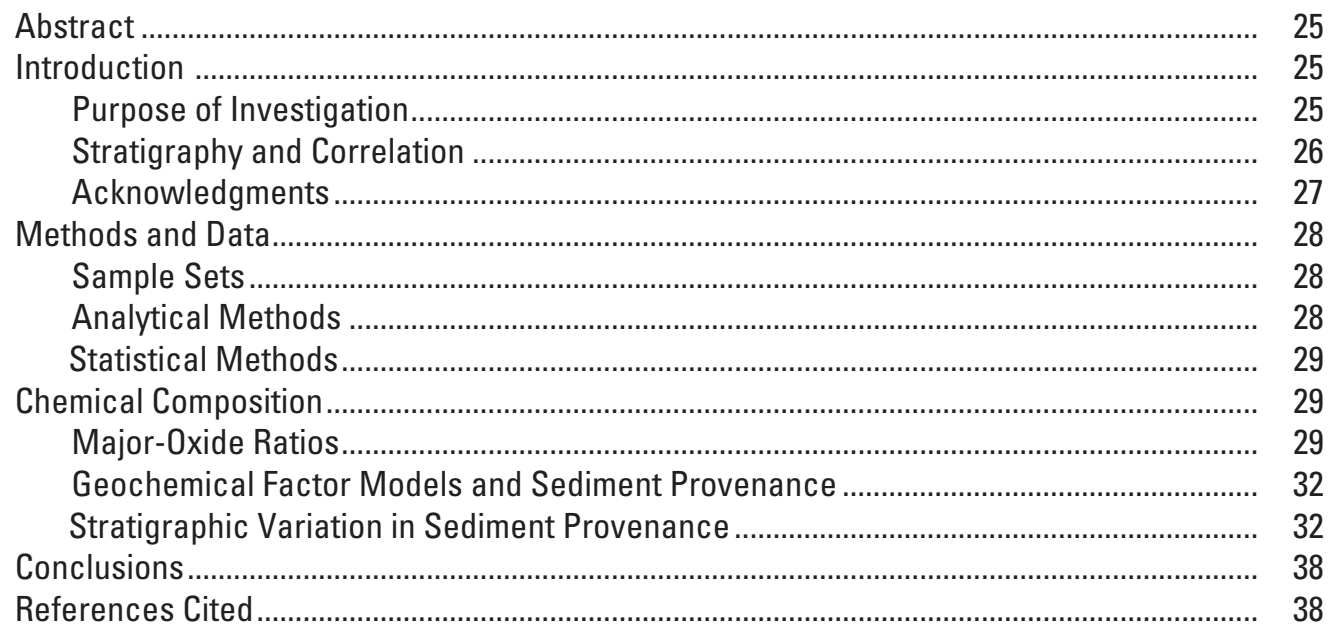

\section{Figures}

1. Index map showing localities of samples for geochemical data sets for metasedimentary rocks of the Mesoproterozoic Lemhi Group, central Idaho

2-5. Scattergrams showing:

2. Chemical classification of rocks of the Big Creek, Apple Creek, and Gunsight Formations by $\log \left(\mathrm{Fe}_{\mathrm{T}} \mathrm{O}_{3} / \mathrm{K}_{2} \mathrm{O}\right)$ versus $\log \left(\mathrm{SiO}_{2} / \mathrm{Al}_{2} \mathrm{O}_{3}\right)$

3. Chemical classification of rocks of the Big Creek, Apple Creek, and Gunsight Formations by $\log \left(\mathrm{SiO}_{2} / \mathrm{Al}_{2} \mathrm{O}_{3}\right)$ versus $\log \left(\mathrm{K}_{2} \mathrm{O} / \mathrm{Na}_{2} \mathrm{O}\right)$

4. Major oxides and elements, showing effect of plagioclase content on geochemical covariation in rocks of the Apple Creek and Gunsight Formations, Salmon River Mountains

5. Log $\mathrm{CaO}$ versus $\log \mathrm{Na}_{2} \mathrm{O}$, showing effect of plagioclase and calcite content on major-oxide covariation in rocks of the Big Creek and Apple Creek Formations, Lemhi Range.

6. Box plots showing $\mathrm{CaO}$ and $\mathrm{Na}_{2} \mathrm{O}$ content of siltite in the Big Creek and Apple Creek Formations, Lemhi Range

\section{Tables}

1. Stratigraphic units and relationships in the Mesoproterozoic Lemhi Group, eastern part of the Salmon River Mountains and northern part of the Lemhi Range, central Idaho.

2. Samples of metasedimentary rocks of the Mesoproterozoic Lemhi Group classified by formation (including facies and units) and rock type,

Salmon River Mountains and Lemhi Range, central Idaho.

3. R-mode factor analysis of geochemical data, Apple Creek and

Gunsight Formations, Salmon River Mountains

4. R-mode factor analysis of geochemical data, Big Creek and Apple Creek Formations, Lemhi Range...

5. Analysis of variance and Fisher's PLSD test for differences among mean values for factor 2 scores, $\log \mathrm{CaO}$, and $\log \mathrm{Na}_{2} \mathrm{O}$ in siltite samples from the Big Creek and Apple Creek Formations, Lemhi Range 


\title{
Chemical Composition and Provenance of the Mesoproterozoic Big Creek, Apple Creek, and Gunsight Formations, Lemhi Group, Central Idaho
}

\author{
By David A. Lindsey, Russell G. Tysdal, and Joseph E. Taggart, Jr.
}

\section{Abstract}

Grain size and provenance strongly influence the chemical composition of metasedimentary rocks of the Mesoproterozoic Big Creek, Apple Creek, and Gunsight Formations of the Lemhi Group. In this report, we use major-oxide ratios, statistical analysis of covariation (R-mode factor analysis) among major oxides and trace elements, and analysis of variance among stratigraphic units to examine the relation between provenance and chemical composition. Plagioclase, an important indicator of provenance, is widespread and abundant in the the Big Creek, Apple Creek, and Gunsight Formations. Plagioclase increases the abundance of noncarbonate $\mathrm{CaO}, \mathrm{Na}_{2} \mathrm{O}$, and $\mathrm{Sr}$, and decreases the ratio of $\mathrm{K}_{2} \mathrm{O}$ to $\mathrm{Na}_{2} \mathrm{O}$.

Before metamorphism, rocks of the Big Creek, Apple Creek, and Gunsight Formations were for the most part firstcycle clastic sediments derived from a terrane having the majoroxide composition of gneiss like that of the Archean quartzofeldspathic gneiss (also known as the "Dillon Granite Gneiss") of southwestern Montana. Argillite, diamictite, and siltite plot mostly in the wacke (graywacke) field of the scattergram log $\left(\mathrm{Fe}_{\mathrm{T}} \mathrm{O}_{3} / \mathrm{K}_{2} \mathrm{O}\right)$ versus $\log \left(\mathrm{SiO}_{2} / \mathrm{Al}_{2} \mathrm{O}_{3}\right)$, reflecting the abundance of mica and chlorite (originally, clay) versus quartz. Metasandstones tend to plot in the fields of wacke, arkose, and litharenite (lithic arenite), suggesting that a wide variety of matrix-rich, arkosic, and lithic sandstones were originally present in the Lemhi Group. Major-oxide ratios of the Big Creek, Apple Creek, and Gunsight Formations are only slightly evolved from those of quartzo-feldspathic gneiss.

A notable feature of scattergrams showing $\log \left(\mathrm{SiO}_{2} / \mathrm{Al}_{2} \mathrm{O}_{3}\right)$ versus $\log \left(\mathrm{K}_{2} \mathrm{O} / \mathrm{Na}_{2} \mathrm{O}\right)$ is the strong linear variation in $\log \left(\mathrm{K}_{2} \mathrm{O} /\right.$ $\mathrm{Na}_{2} \mathrm{O}$ ). Although this variation may result from mixing of two source rocks, one $\mathrm{K}_{2} \mathrm{O}$ (potassium feldspar)-rich and one $\mathrm{Na}_{2} \mathrm{O}$ (plagioclase)-rich, it more likely reflects varying degrees of weathering of a plagioclase-rich source such as gneiss.

Four petrologic processes were interpreted by R-mode factor analysis of geochemical data for the Apple Creek and Gunsight Formations in the Salmon River Mountains. Factors are (1) micas and chlorite (grain size of original sediment), (2) rare earth minerals (provenance or metamorphism), (3) base-metal mineralization, and (4) plagioclase (provenance). The factor interpretation for geochemical data from the Big Creek and Apple Creek Formations of the Lemhi Range is similar, except that mineralization is not well developed and placer concentration of iron oxide minerals is evident in the Big Creek Formation. In both ranges, $\mathrm{CaO}$ and $\mathrm{Na}_{2} \mathrm{O}$ have high loadings on the plagioclase factor. In metasandstones of the Salmon River Mountains, the linking of $\mathrm{CaO}$ and $\mathrm{Na}_{2} \mathrm{O}$ to plagioclase is confirmed by their correlation with estimates of modal plagioclase in thin section.

To varying degrees, plagioclase was destroyed during weathering of the source area and transit to the depositional basin. In the Lemhi Range, plagioclase content of the Apple Creek and Big Creek Formations is best represented by $\mathrm{Na}_{2} \mathrm{O}$. $\mathrm{Na}_{2} \mathrm{O}$ varies among stratigraphic units in the Apple Creek and Big Creek Formations, indicating sources of varying composition or varying rates of weathering, erosion, and sediment transport during deposition of this part of the Lemhi Group.

\section{Introduction}

\section{Purpose of Investigation}

This investigation is aimed at identifying the provenance of the Mesoproterozoic Lemhi Group of central Idaho. Provenance encompasses the composition of the source, the nature and degree of weathering in the source, and the weathering history of detritus during transit. Understanding provenance is important to the correlation and interpretation of the plate-tectonic setting of Mesoproterozoic rocks in Idaho and Montana. Within the Lemhi Group, the Mesoproterozoic Big Creek, Apple Creek, and Gunsight Formations were selected for provenance studies because of their wide distribution and availability of geochemical data.

Previous investigations revealed that many of the metasandstones in Mesoproterozoic formations of central Idaho are arkosic (Lopez, 1981; Ruppel, 1975). In the Lemhi Range, these formations include the Mesoproterozoic Big Creek, Apple Creek, and Gunsight Formations of the Lemhi Group (Ruppel, 1975). In the Salmon River Mountains, arkosic metasandstones are found in rocks now correlated with the Lemhi Group (Tysdal, 2000a) but formerly assigned to the Mesoproterozoic Yellowjacket Formation (Lopez, 1981; Connor and Evans, 1986; Evans and Connor, 1993). In both ranges, as well as in the Beaverhead Mountains, arkosic metasandstones of the Gunsight Formation contain abundant plagioclase as well as potassium feldspar (McBean, 1983). At Ayers Canyon, about $25 \mathrm{~km}$ east of Leadore in the Beaverhead Mountains (fig. 1), conglomeratic metasandstone assigned to the Gunsight Formation contains abundant pebbles of gneiss (McBean, 1983; M'Gonigle, 1993). Clasts in the only other conglomerate in the Lemhi Group, the diamictite unit of the Apple Creek Formation in the northern Lemhi Range, are mostly intrabasinal argillite, siltstone, and sandstone (Tietbohl, 1986). 


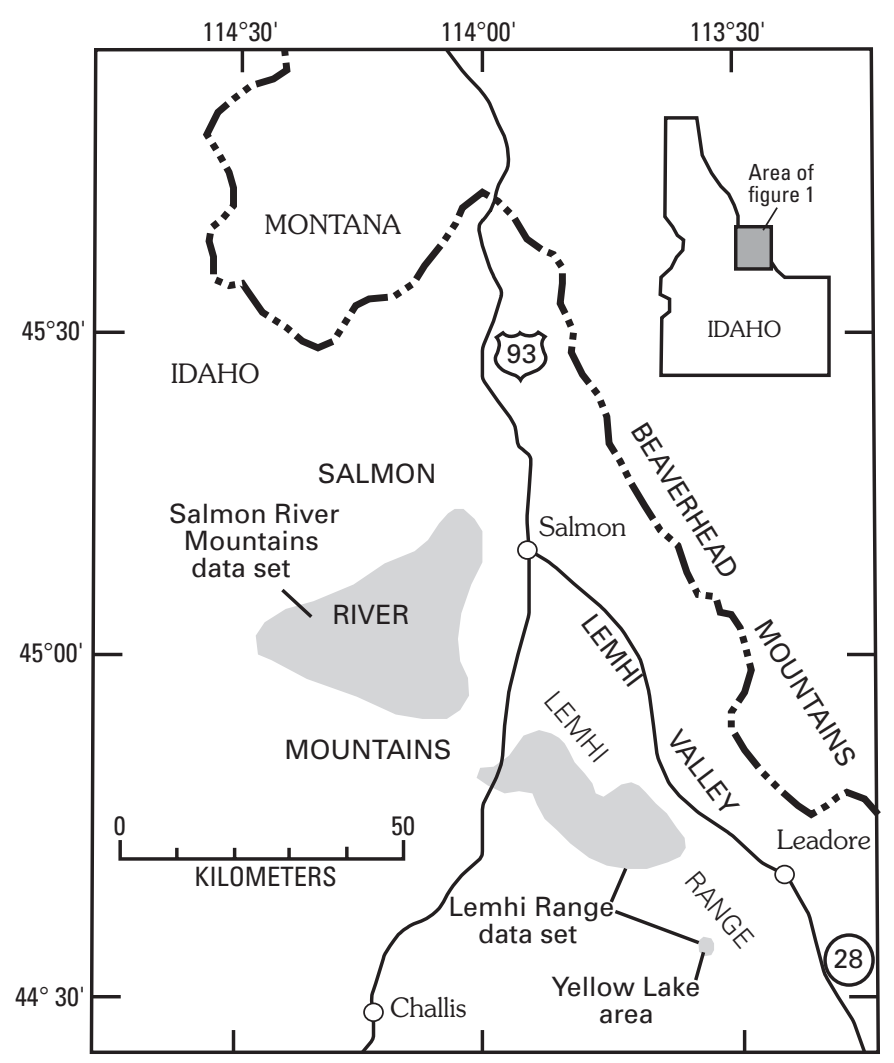

Figure 1. Index map showing generalized localities of samples for geochemical data sets for metasedimentary rocks of the Mesoproterozoic Lemhi Group, Salmon River Mountains and Lemhi Range, central Idaho. Sampled areas are shaded.

In this report, we draw on a detailed statistical analysis of two geochemical data sets (Lindsey and others, 2002) ${ }^{1}$ to infer the provenance of the Big Creek, Apple Creek, and Gunsight Formations of the Lemhi Group. In these formations, the abundance of noncarbonate $\mathrm{CaO}, \mathrm{Na}_{2} \mathrm{O}$, and $\mathrm{Sr}$, and the ratio $\mathrm{K}_{2} \mathrm{O}$ / $\mathrm{Na}_{2} \mathrm{O}$, are dependent upon the abundance of plagioclase, a major indicator of provenance in arkosic rocks.

Although rocks of the Lemhi Group have been metamorphosed to greenschist facies, with metamorphic biotite common in the Salmon River Mountains, clastic metasedimentary textures and structures are evident (Lopez, 1981; Tysdal, 2000b). Comparison of the major-oxide composition of siltite in the more highly metamorphosed rocks (biotite-grade greenschist facies) of the Salmon River Mountains with the composition of siltite in the less metamorphosed (chlorite-grade greenschist facies) rocks of the same unit in the Lemhi Range indicates that modification of the original chemical composition is probably minimal (Lindsey and others, 2002).

'This open-file report contains tables and figures showing details of geochemical relationships. An online version, including geochemical data sets for the Salmon River Mountains and the Lemhi Range, is available at <http:// geology.cr.usgs.gov/pub/open-file-reports/ofr-02-0310/>.

\section{Stratigraphy and Correlation}

The stratigraphy of the Mesoproterozoic Lemhi Group in the Lemhi Range and rocks prevously assigned to the Yellowjacket Formation in the Salmon River Mountains has been recently clarified (Tysdal, 2000a, 2000b; this volume) (table 1). The Lemhi Group of the Lemhi Range (Ruppel, 1975) has been correlated with rocks previously mapped as Mesoproterozoic Yellowjacket Formation in the Salmon River Mountains (Connor and Evans, 1986; Connor, 1990; Evans and Connor, 1993). The basis for stratigraphic revision and correlation was established by geologic mapping of key areas in the northern Lemhi Range and the Beaverhead Mountains (Tysdal, 1996a, 1996b; Tysdal and Moye, 1996; Tysdal, Evans, and Lund, 2000). During the course of mapping in the northern part of the Lemhi Range, the Mesoproterozoic Big Creek Formation and the overlying Apple Creek Formation were described and subdivided (Tysdal, 2000a, 2000b).

The Apple Creek Formation was divided into four units by Tysdal (2000a) (table 1). Three of these units crop out over extensive areas in the northern Lemhi Range. In ascending order, the Apple Creek contains the fine siltite unit, the diamictite unit, and the coarse siltite unit. The diamictite unit thins westward in the Lemhi Range and apparently pinches out at the east edge of the Salmon River Mountains (Connor, 1990; Tysdal and Moye, 1996). Tysdal (2000a, 2000b) correlated the overlying coarse siltite unit with part of the Salmon River Mountains sequence of strata that Connor and Evans (1986) and Connor (1990) previously had mapped as the "lower subunit of the Yellowjacket Formation," and applied the Apple Creek name to these strata. The conformably overlying "middle subunit of the Yellowjacket Formation" of these workers was renamed the banded siltite unit and placed in the upper part of the Apple Creek by Tysdal (this volume). At Yellow Lake in the Lemhi Range, the Apple Creek Formation unconformably overlies the Big Creek Formation and is transitional into the overlying Gunsight Formation (Tysdal, 2000b). The Apple Creek Formation (undivided) at Yellow Lake is designated the "Yellow Lake unit."

The Big Creek Formation is light-gray, coarse-grained siltite to medium-grained quartz-feldspar metasandstone. It contains prominent rusty-brown-weathering layers of carbonatecemented sandstone and laminae of dark-gray heavy minerals. The formation is about 2,700 $\mathrm{m}$ thick in the northern Lemhi Range. The fine siltite unit of the Apple Creek Formation is planar-laminated siltite, ripple cross-laminated siltite, and argillaceous siltite. Many beds are graded, with 1-2 cm thick layers of siltite grading upward into argillite. The unit is estimated to be about $1,000 \mathrm{~m}$ thick. The diamictite unit of the Apple Creek is composed of poorly sorted conglomerate beds, 1-5 $\mathrm{m}$ in thickness, of disorganized, matrix-supported clasts; the conglomerate beds are interpreted as turbidites and debris flows. Argillite, argillaceous siltite, siltite, and lesser metasandstone form successions as much as $10 \mathrm{~m}$ or more thick between conglomerate beds. These fine-grained strata are turbidites. The thickness range in the northern part of the Lemhi Range is about 600-1,500 m. The coarse siltite unit of the Apple Creek 
Table 1. Stratigraphic units and relationships in the Mesoproterozoic Lemhi Group, eastern part of the Salmon River Mountains and northern part of the Lemhi Range.

[Includes units sampled for this study (compiled from Tysdal, 1996a, 1996b; Tysdal, 2000a, 2000b; Tysdal and Moye, 1996; and Tysdal, Evans, and Lund, 2000)]

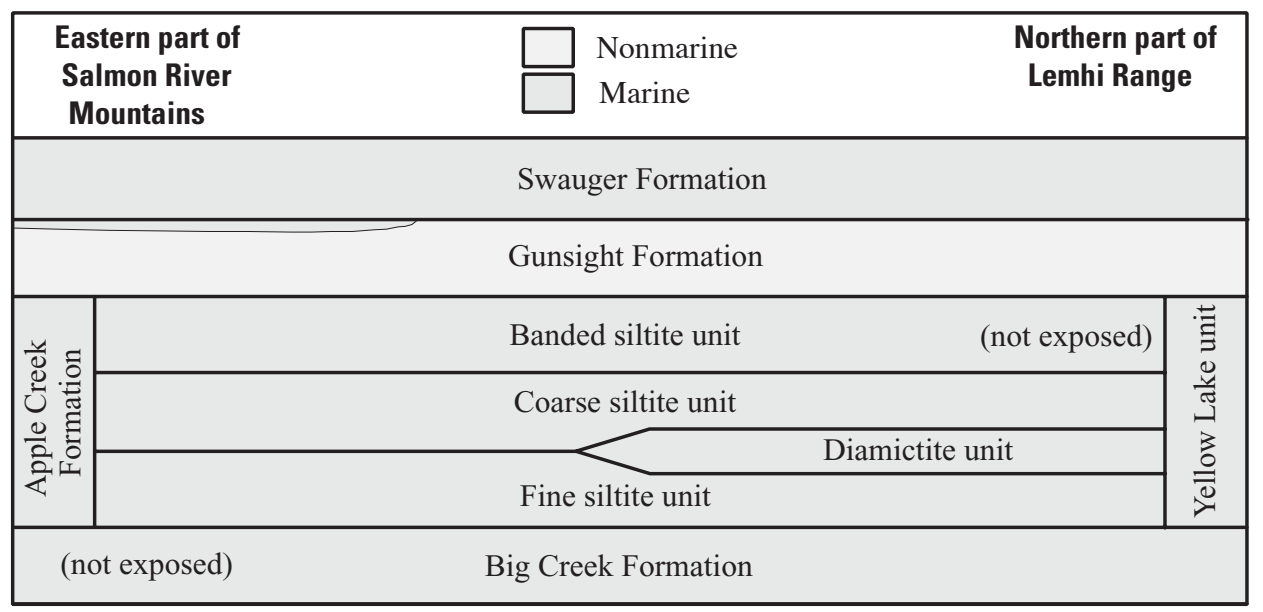

is composed of medium- to coarse-grained siltite and finegrained metasandstone. Siltite beds are normally graded, and soft-sediment deformation structures are common. The unit derives its name from distinctive graded beds of sharp-based, light-gray, quartz-rich, fine-grained metasandstone interspersed within the sequence. The graded bedding of the siltite and the sharp-based, light-gray metasandstone beds suggest deposition from turbidity currents. The coarse siltite unit is about $2,500 \mathrm{~m}$ thick (Tysdal, 2000b).

The banded siltite unit is a distinct facies of the Apple Creek and is preserved mainly in the Salmon River Mountains (fig. 1). Connor (1990) described the rocks as plane-parallel, laminated to thin-bedded siltite-argillite couplets that are blackand-white. The white (light-gray) beds are quartz-rich siltite to fine-grained metasandstone and the black beds are argillite. The planar bedding is strongly disrupted locally by soft-sediment deformation. The unit is interpreted as a turbidite sequence by Sobel (1982) and Tysdal (this volume), and has an estimated thickness of 2,000 m (Connor and Evans, 1986).

The Yellow Lake unit of the Apple Creek Formation (in the Lemhi Range) consists mainly of dark-gray medium- and finegrained laminated siltite, and locally argillite in the lower part (Tysdal, 2000b). Some siltite beds exhibit scoured bases, graded tops, ripple crosslamination, slump folds, and fluid-escape structures. Much of the Yellow Lake unit contains dolomitic beds and laminae, which serve to distinguish this unit from other units of the Apple Creek Formation. The upper part of the Yellow Lake unit also contains interbeds of light-gray feldspathic metasandstone.

The Gunsight Formation was named by Ruppel (1975) for a sequence of metasandstone and finer clastic rocks in the Gunsight Peak area of the Lemhi Range. At the type locality, the Gunsight is 1,700+ $\mathrm{m}$ thick (McBean, 1983). The formation consists mainly of fining-upward sequences of crossbedded metasandstone and siltite of probable fluvial origin. The lower and upper parts of the Gunsight Formation may be marine in part. The lowermost Gunsight is transitional into turbidites of the Apple Creek Formation. The uppermost Gunsight is transitional into marine orthoquartzite of the Mesoproterozoic Swauger Formation (Tysdal, 2000b).

Although various correlations of the Lemhi Group with the Mesoproterozoic Belt Supergroup have been proposed (Ruppel and Lopez, 1988; Winston and others, 1999), the true stratigraphic relationship between the Lemhi Group and the Belt is unknown. Previously proposed correlations were made before rocks assigned to the Yellowjacket Formation in the Salmon River Mountains were correlated with the Lemhi Group (Tysdal, 2000a). Differences in the paleogeographic configuration of basins and source areas during deposition of the Lemhi Group and the Belt Supergroup also pose a challenge to correlation. During deposition of sediments that formed the Mesoproterozoic Gunsight Formation, the source lay to the northeast, in the Archean gneiss terrane of southwestern Montana (R.G. Tysdal, D.A. Lindsey, and K.I. Lund, unpub. data, 2002). In the Belt Supergroup, the Mesoproterozoic Prichard and Revett Formations were derived from a land mass that lay to the west and south, in the area currently occupied by the Lemhi Group (Cressman, 1989; Ryan and Buckley, 1999). The depositional basin for the Lemhi Group could not have been located in the Prichard-Revett source area while the latter was being eroded.

\section{Acknowledgments}

We especially acknowledge J.J. Connor, who collected and documented samples for the Salmon River Mountains data set and part of the Lemhi Range data set, used in this study. Chemical analyses of rocks from the Salmon River Mountains (Connor, 1990) were made by A.J. Bartel, E. Brandt, P.H. Briggs, S. Danahey, D. Fey, D.B. Hatfield, M. Malcolm, V. Merritt, G. Riddle, S. Roof, K. Stewart, J. Storey, J.E. Taggart, Jr., and R.B. Vaughn, U.S. Geological Survey. Analyses of rocks from the Lemhi Range were made by P.H. Briggs, D.E. Detra, D.L. Fey, R.T. Hopkins, J.M. Motooka, J.E. Taggart, Jr., and K. Slaughter, U.S. Geological Survey. Ten samples from the Lemhi Range 
Table 2. Samples of metasedimentary rocks of the Mesoproterozoic Lemhi Group classified by formation (including facies and units) and rock type, Salmon River Mountains and Lemhi Range, central Idaho.

[Ygf, fluvial facies of Gunsight Formation; Ygm, marine facies of Gunsight Formation; Yay, Yellow Lake unit of Apple Creek Formation; Yab, banded siltite unit of Apple Creek Formation; Yac, coarse siltite unit of Apple Creek Formation; Yad, diamictite unit of Apple Creek Formation; Yaf, fine siltite unit of Apple Creek Formation; Yb, Big Creek Formation. Stratigraphic nomenclature of Tysdal (2000a)]

\begin{tabular}{|c|c|c|c|c|c|}
\hline Formation & Total & Sandstone & Siltite & Argillite & Diamictite \\
\hline \multicolumn{6}{|c|}{ Salmon River Mountains } \\
\hline Ygf & 11 & 7 & 0 & 4 & 0 \\
\hline Ygm & 10 & 10 & 0 & 0 & 0 \\
\hline Yab & 37 & 10 & 7 & 20 & 0 \\
\hline Yac & 40 & 7 & 15 & 18 & 0 \\
\hline Total & 98 & 34 & 22 & 42 & 0 \\
\hline \multicolumn{6}{|c|}{ Lemhi Range } \\
\hline Yay & 6 & 1 & 3 & 2 & 0 \\
\hline Yac & 21 & 0 & 21 & 0 & 0 \\
\hline Yad & 49 & 0 & 25 & 0 & 24 \\
\hline Yaf & 15 & 7 & 8 & 0 & 0 \\
\hline $\mathrm{Yb}$ & 36 & 16 & 20 & 0 & 0 \\
\hline Unknown & 1 & 0 & 1 & 0 & 0 \\
\hline Total & 128 & 24 & 78 & 2 & 24 \\
\hline
\end{tabular}

(Connor, 1991) were analyzed by A.J. Bartel, P.H. Briggs, R.R. Carlson, J.G. Crock, C.S.E. Papp, B.H. Roushey, D.F. Siems, J.E. Taggart, Jr., and E.P. Welsch, U.S. Geological Survey. K.V. Evans and W.R. Miller reviewed the manuscript.

\section{Methods and Data}

\section{Sample Sets}

Two geochemical sample data sets (online version of Lindsey and others, 2002) were examined for evidence of the petrologic processes, including sediment provenance, that formed the Mesoproterozoic rocks in central Idaho. One data set was selected from samples collected by J.J. Connor during an earlier study of rocks formerly assigned to the Mesoproterozoic Yellowjacket Formation in the Salmon River Mountains (Connor, 1990) (fig. 1). The Salmon River Mountains data set represents rocks of the Apple Creek and Gunsight Formations (table 2). A second data set was selected from samples collected by R.G. Tysdal, during study of the Lemhi Group in the northern part of the Lemhi Range, and augmented by 10 samples from a larger set collected by J.J. Connor (Connor, 1991) (fig. 1). The Lemhi Range data set represents rocks of the Big Creek and Apple Creek Formations (table 2).

The samples of Connor (1990) from the Salmon River Mountains were reassigned to formations of the Lemhi Group by R.G. Tysdal (2000a) (table 1). Reassignment became necessary after Tysdal (Tysdal, 1996a, 1996b; Tysdal and Moye, 1996) mapped the Lemhi Group in the northern part of the Lemhi Range and realized that the stratigraphic units there were equivalent to rocks in the Salmon River Mountains, formerly assigned to the Yellowjacket Formation. Samples from outlying areas, from the type Yellowjacket Formation, and from the Mesoproterozoic Hoodoo Quartzite, all of uncertain stratigraphic relation to the Lemhi Group, were excluded from the Salmon River Mountains data set. Also excluded were a few samples of unusual rock types, including banded iron-formation, tourmalinite breccia, one diamictite, and biotitite (biotite-rich schist). The resulting Salmon River Mountains sample set, used in this investigation, contained 98 samples of quartzite (metasandstone, hereafter referenced as "sandstone"), siltite, and argillite (table 2). The more or less even distribution of samples, with the exception of siltite and argillite in the Gunsight Formation, makes the Salmon River data set amenable to statistical comparisons among formations and rock types.

Rock types represented in the Lemhi Range data set are mostly sandstone, siltite, and diamictite, but more than half the samples (78) are siltite (table 2). Most sandstone samples (16) are from the Big Creek Formation, whereas diamictite is entirely from one unit of the Apple Creek Formation. Most siltite samples are nearly evenly distributed among the Big Creek Formation and two units of the Apple Creek Formation, providing a good case for examining stratigraphic variation in those units.

\section{Analytical Methods}

The data set from the Salmon River Mountains (Connor, 1990) contains analyses of major oxides and numerous trace elements, making it ideal for identification of petrogenetic factors affecting rock composition. Major oxides were analyzed by Xray fluorescence spectrometry (Taggart and others, 1987). Most trace elements were analyzed by inductively coupled plasmaatomic absorption emission spectroscopy (Lichte and others, 1987), except thorium and uranium, which were determined by the delayed-neutron method (McKown and Millard, 1987).

Methods of chemical analysis, descriptions of sample sets, and estimates of analytical error are given by Connor (1990).

The sample set from the Lemhi Range was originally analyzed for trace elements by the six-step semiquantitative spectrographic method (Golightly and others, 1987), except for 10 
samples reported by Connor (1991), which were analyzed by inductively coupled plasma-atomic absorption emission spectroscopy (Lichte and others, 1987). Some samples were analyzed for selected major oxides and trace elements by other methods, but these data were not used in this report. The formerly incomplete analyses of major oxides were supplanted by more recent analyses of all major oxides by X-ray fluorescence spectrometry (Taggart and others, 1987). These majoroxide analyses are available in the online version of Lindsey and others (2002). Additional analytical data, except the recently completed X-ray fluorescence analyses, are available in CDROM form (Baedecker and others, 1998).

\section{Statistical Methods}

We examined geochemical data by comparing scattergrams of major-oxide ratios, by statistical analysis of covariation (Rmode factor analysis) among major oxides and trace elements, and by analysis of variance of the same data for stratigraphic variation. Details of statistical methods are described in Lindsey and others (2002).

The major-oxide composition of the Big Creek, Apple Creek, and Gunsight Formations was investigated by use of logratio $^{2}$ scattergrams (Pettijohn and others, 1972; Lindsey, 1999). In sandstones, $\log \left(\mathrm{SiO}_{2} / \mathrm{Al}_{2} \mathrm{O}_{3}\right)$ is a measure of quartz versus feldspar plus clay, and thus is an indicator of chemical and textural maturity. In clay-rich clastic rocks such as siltstone and shale, $\log \left(\mathrm{SiO}_{2} / \mathrm{Al}_{2} \mathrm{O}_{3}\right)$ is essentially a measure of detrital quartz versus clay and thus, grain size. $\log \left(\mathrm{K}_{2} \mathrm{O} / \mathrm{Na}_{2} \mathrm{O}\right)$ reflects the nature of the source and the degree of weathering and diagenesis. Plagioclase, especially intermediate to calcic plagioclase, is more easily destroyed (converted to clay and soluble ions) by chemical weathering than is potassium feldspar, and hence, log $\left(\mathrm{K}_{2} \mathrm{O} / \mathrm{Na}_{2} \mathrm{O}\right)$ increases with weathering of a two-feldspar rock. These ratios are combined in scattergrams to classify sandstones and other siliciclastic sedimentary rocks (Pettijohn and others, 1972; Lindsey, 1999).

A second scattergram, $\log \left(\mathrm{Fe}_{\mathrm{T}} \mathrm{O}_{3} / \mathrm{K}_{2} \mathrm{O}\right)$ versus $\log \left(\mathrm{SiO}_{2} /\right.$ $\mathrm{Al}_{2} \mathrm{O}_{3}$ ), is useful for distinguishing of some groups of sandstones from argillaceous rocks (Herron, 1988). In fine-grained rocks and matrix-rich sandstone, $\log \left(\mathrm{Fe}_{\mathrm{T}} \mathrm{O}_{3} / \mathrm{K}_{2} \mathrm{O}\right)$ is a measure of the abundance of iron-bearing chlorite versus potassium-bearing clays and micas.

Petrologic processes, including provenance, that affected the chemical composition of the Lemhi Group rocks under study were investigated using R-mode factor analysis (Lindsey and others, 2002). A general discussion of R-mode factor analysis can be found in Cooley and Lohnes (1962); a complete discussion of the methods used here is given by Lindsey and others (2002). Factor models, expressed as factor loading tables, measure the relationship of major oxides and trace elements to a small number of new, uncorrelated variables, called principal components.

${ }^{2} \mathrm{All}$ logarithms in this report are to the base 10 .
To produce a factor model for geochemical data, the data were first screened for completeness, and frequency distributions were examined for skewness. Elements for which a majority of the analyses were below the limit of detection were dropped from consideration; for other elements, values below the limit of detection were replaced by values ranging from $1 / 2$ to $2 / 3$ the limit of detection. Values for oxides and elements whose frequency distribution is highly skewed were transformed to logarithms. The resulting data matrix was used to compute a correlation matrix. The correlation matrix was solved for its latent roots (eigenvalues), and a new matrix specifying uncorrelated vectors (principal component axes) was calculated. A small number of principal components were selected for rotation and factor interpretation, based on the eigenvalues, on communalities, and on ease of interpretation. Selection of the number of principal components to preserve for rotation is somewhat subjective. We used the root curve method to compare eigenvalues (SAS Institute Inc., 1998) and also compared communalities when various numbers of principal components were selected (Lindsey and others, 2002). An evaluation of criteria for selecting the number of principal components for rotation is given by Jackson (1993). After rotation, the principal components are interpreted as petrologic processes, or factors. Interpretation is based on the nature and correlation of elements that load on each factor, the likely mineralogical residence of these elements, and the known conditions for formation and concentration of these minerals. Scattergrams of element pairs and frequency distributions of individual elements are commonly useful in examining the causes of factor loadings.

Stratigraphic variation in provenance was investigated for siltite in the Lemhi Range. Analyses of 66 samples of siltite are nearly evenly distributed among the Big Creek Formation and two units of the Apple Creek Formation (table 2). A simple oneway analysis of variance (Krumbein and Graybill, 1965), accompanied by box plots, was used to test and illustrate stratigraphic variation in provenance. Differences among mean values for stratigraphic units also were tested by Fisher's PLSD (Protected Least Significant Difference) method (discussed by SAS Institute Inc., 1998).

\section{Chemical Composition}

\section{Major-0xide Ratios}

Rocks of varying grain size in the Big Creek, Apple Creek, and Gunsight Formations appear to be well classified by the scattergram $\log \left(\mathrm{Fe}_{\mathrm{T}} \mathrm{O}_{3} / \mathrm{K}_{2} \mathrm{O}\right)$ versus $\log \left(\mathrm{SiO}_{2} / \mathrm{Al}_{2} \mathrm{O}_{3}\right)$ (fig. $2 \mathrm{~A}$, $B)$. Argillite, diamictite, and siltite plot mostly in the wacke (graywacke) field, reflecting abundant mica and chlorite (originally, clay). Very few samples plot in the shale field. In the Salmon River Mountains, siltite is distinguished from argillite by slightly higher ratios of $\log \left(\mathrm{Fe}_{\mathrm{T}} \mathrm{O}_{3} / \mathrm{K}_{2} \mathrm{O}\right)$ and $\log \left(\mathrm{SiO}_{2} /\right.$ $\mathrm{Al}_{2} \mathrm{O}_{3}$ ). In both mountain ranges, sandstones tend to plot in the fields of wacke (graywacke), arkose, and litharenite (lithic arenite), suggesting that a wide variety of matrix-rich, arkosic, and lithic sandstones were originally present in the Lemhi Group. 

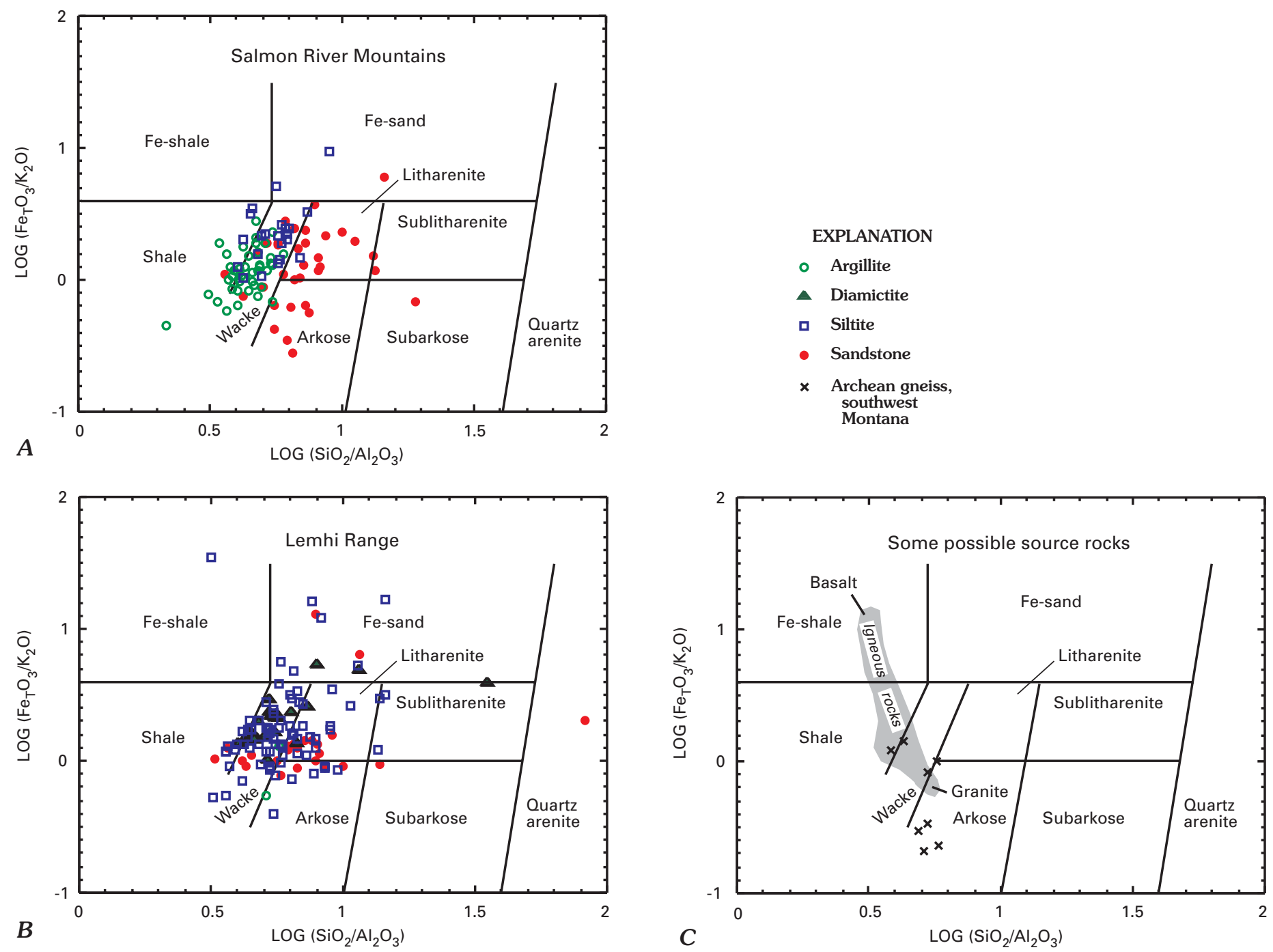

Figure 2. Chemical classification of rocks of the Big Creek, Apple Creek, and Gunsight Formations by $\log \left(\mathrm{Fe}_{\mathrm{T}} \mathrm{O}_{3} / \mathrm{K}_{2} \mathrm{O}\right)$ versus log $\left(\mathrm{SiO}_{2} / \mathrm{Al}_{2} \mathrm{O}_{3}\right)(\mathrm{meth}$ od of Herron, 1988) compared to possible source rocks. $A$, Salmon River Mountains; $B$, Lemhi Range; $C$, some possible source rocks, including Archean gneiss, Tobacco Root and Ruby Ranges (Anderson and others, 1990; James, 1990; Wilson, 1981), and common igneous rocks (data from Le Maitre, 1976). $\mathrm{Fe}_{\mathrm{T}} \mathrm{O}_{3}$, total iron as $\mathrm{Fe}_{2} \mathrm{O}_{3}$.

Before metamorphism, rocks of the Big Creek, Apple Creek, and Gunsight Formations were for the most part firstcycle arkosic sediments. Low $(<1)$ ratios of $\log \left(\mathrm{SiO}_{2} / \mathrm{Al}_{2} \mathrm{O}_{3}\right)$ indicate that these sediments were chemically and mineralogically immature (silica- and quartz-poor). Comparison with Archean quartzo-feldspathic gneiss ("Dillon Granite Gneiss" of early reports) of the Tobacco Root and Ruby Ranges (fig. 2C) indicates that the composition of the Lemhi Group is only slightly evolved from gneiss. Archean quartzo-feldspathic gneiss is a major unit in the Precambrian terrane of southwestern Montana; for example, the gneiss makes up a major part of the southwestern Ruby Range (James, 1990). The major-oxide content of Archean quartzo-feldspathic gneiss in southwestern Montana is also comparable to that of granitic rocks (fig. $2 C$ ), which may have been the protolith (James, 1990). Alternatively, the gneiss may have been formed from both sedimentary and igneous rocks (Garihan and Williams, 1976; Wilson, 1981). On the basis of major-oxide content, the quartzo-feldspathic gneiss is a possible source, or at least an analog for a source, of detritus in the Lemhi Group.

A notable feature of scattergrams showing $\log \left(\mathrm{K}_{2} \mathrm{O} /\right.$ $\mathrm{Na}_{2} \mathrm{O}$ ) is the strong linear trend of Lemhi Group rocks, reflecting a wide variation in $\mathrm{K}_{2} \mathrm{O} / \mathrm{Na}_{2} \mathrm{O}$ (fig. $3 A, B$ ). This variation may result from (1) mixing of two source rocks, one $\mathrm{K}_{2} \mathrm{O}$ (potassium feldspar)-rich and one $\mathrm{Na}_{2} \mathrm{O}$ (plagioclase)-rich; (2) varying degrees of weathering of initially $\mathrm{Na}_{2} \mathrm{O}$ (plagioclase)rich rock, either in the source area, during transit to the depositional basin, or both; and (3) postdepositional alteration and alkali metasomatism. If $\log \left(\mathrm{K}_{2} \mathrm{O} / \mathrm{Na}_{2} \mathrm{O}\right)$ values represent mixing of two rock types, then the ratios at the ends of the line should approximate those of the source rocks. If $\log \left(\mathrm{K}_{2} \mathrm{O} /\right.$ $\mathrm{Na}_{2} \mathrm{O}$ ) represents weathering of an originally $\mathrm{Na}_{2} \mathrm{O}$ (plagioclase)-rich source rock, then the ratio at the $\mathrm{Na}_{2} \mathrm{O}$-rich end of the trend should approximate the value of the source. If $\log$ 


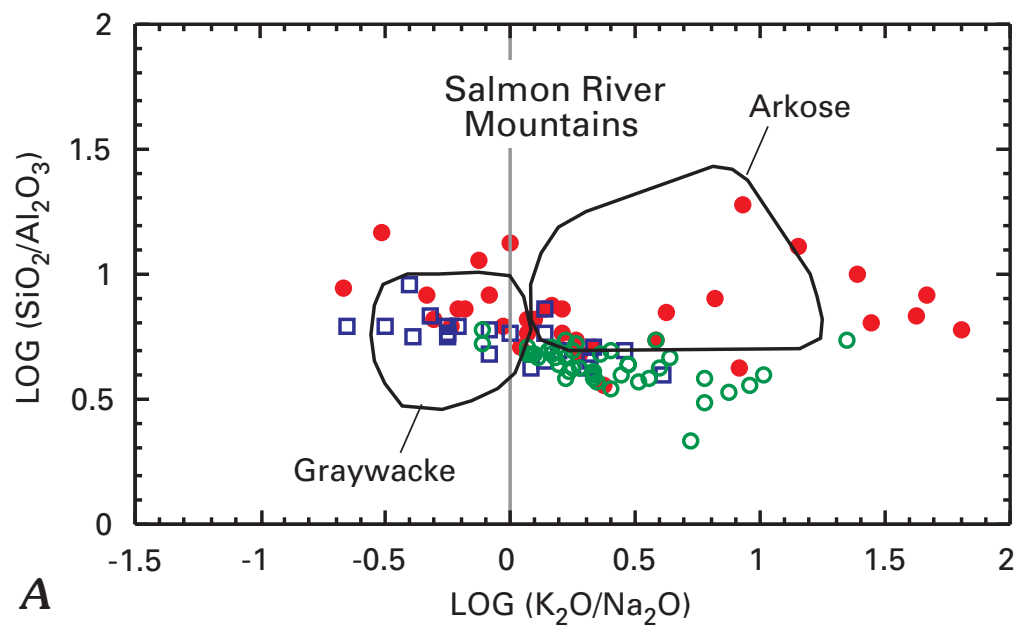

\section{EXPLANATION}

○ Argillite

A Diamictite

․ Siltite

- Sandstone

$\times$ Archean gneiss, southwest

Montana
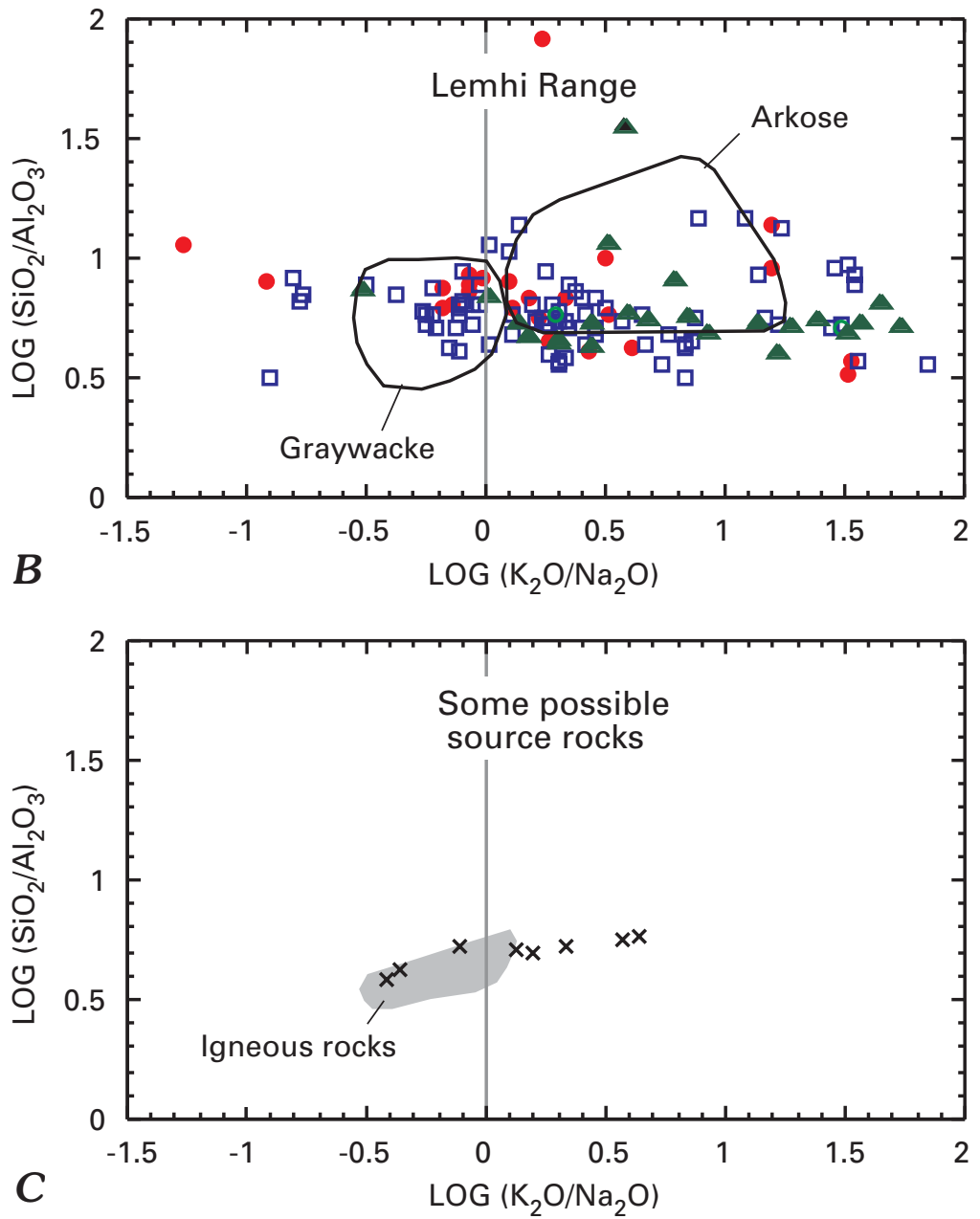

Figure 3. Chemical classification of rocks of the Big Creek, Apple Creek, and Gunsight Formations by log $\left(\mathrm{SiO}_{2} / \mathrm{Al}_{2} \mathrm{O}_{3}\right)$ versus $\log \left(\mathrm{K}_{2} \mathrm{O} / \mathrm{Na}_{2} \mathrm{O}\right)$ (modified method of Pettijohn and others, 1972) compared to possible source rocks. $A$, Salmon River Mountains; $B$, Lemhi Range; $C$, some possible source rocks, including Archean gneiss, Tobacco Root and Ruby Ranges (Anderson and others, 1990; James, 1990; Wilson, 1981), and common igneous rocks (data from Le Maitre, 1976). Also shown in $A$ and $B$, ranges of representative graywacke and arkose (Pettijohn and others, 1972).

$\left(\mathrm{K}_{2} \mathrm{O} / \mathrm{Na}_{2} \mathrm{O}\right)$ represents postdepositional alteration, then the ends of the line represent the range between original rock composition and maximum alteration. Commonly, in unmetamorphosed arkosic rocks, weathering of the source area and sediment during transit is the probable cause of variation in log
$\left(\mathrm{K}_{2} \mathrm{O} / \mathrm{Na}_{2} \mathrm{O}\right)$. (See Van de Kamp and Leake, 1994, for example.)

Comparison of $\log \left(\mathrm{SiO}_{2} / \mathrm{Al}_{2} \mathrm{O}_{3}\right)$ versus $\log \left(\mathrm{K}_{2} \mathrm{O} / \mathrm{Na}_{2} \mathrm{O}\right)$ for the Big Creek, Apple Creek, and Gunsight Formations with Archean gneiss of the Tobacco Root and Ruby Ranges (fig. 3C) 
is consistent with derivation from gneiss. Values of $\log \left(\mathrm{K}_{2} \mathrm{O}\right.$ / $\mathrm{Na}_{2} \mathrm{O}$ ) for Archean gneiss compare closely with the $\mathrm{Na}_{2} \mathrm{O}$ end member of the trend $\log \left(\mathrm{SiO}_{2} / \mathrm{Al}_{2} \mathrm{O}_{3}\right)$ versus $\log \left(\mathrm{K}_{2} \mathrm{O} / \mathrm{Na}_{2} \mathrm{O}\right)$ seen in rocks of the Lemhi Group. Values of $\log \left(\mathrm{K}_{2} \mathrm{O} / \mathrm{Na}_{2} \mathrm{O}\right)$ for most of the Lemhi Group could have been produced by preferential weathering of plagioclase (and removal of $\mathrm{Na}_{2} \mathrm{O}$ ) in gneiss.

A large contribution of detritus from Archean gneiss is not compatible with what is known about the Nd-isotope composition of rocks of the Lemhi Group (previously assigned to the Yellowjacket Formation) in the Salmon River Mountains. According to Doughty and Chamberlain (1996), most of the detritus in rocks of the Lemhi Group of the Salmon River Mountains was derived from a Proterozoic terrane, with only minor contributions from Archean rocks. Although it may not be appropriate to compare the major-oxide composition of rocks of the Lemhi Group with that of Archean gneiss in southwestern Montana, no other nearby pre-Lemhi Group gneiss terrane is available for comparison. Moreover, sedimentary features in the Gunsight Formation point to a source in southwestern Montana (R.G. Tysdal, D.A. Lindsey, and K.I. Lund, unpub. data, 2002).

\section{Geochemical Factor Models and Sediment Provenance}

Four factors were interpreted from R-mode factor analysis of geochemical data for the Apple Creek and Gunsight Formations in the Salmon River Mountains (table 3) (Lindsey and others, 2002). Factor interpretations are (1) micas and chlorite (grain size of original sediment), (2) rare earth minerals (metamorphism or provenance), (3) base-metal mineralization, and (4) plagioclase (provenance). A four-factor solution was selected after inspection of eigenvalues on a graph (root curve method) and comparison of communalities for various solutions involving factors other than four (Lindsey and others, 2002). Interpretations are based primarily on the genetic implications of oxides and elements that have loadings $>0.50$ on one factor - in other words, elements that have at least $0.25(0.50$ squared) of their total variance explained by one factor.

The provenance implications of factor 4 (plagioclase) will be discussed here in preference to those of factor 2 (rare earth minerals). The mineralogical residence of factor 2 elements remains uncertain, and the genetic significance of factor 2 also remains uncertain; therefore, extensive interpretation seems unjustified. Factor 2 may reflect sphene, which is commonly observed in thin sections. Sphene was formed, or recrystallized, during regional metamorphism. If factor 2 elements are present mainly in sphene, this mineral, or its precursors, also accounted for the premetamorphic concentration of rare earth elements.

The interpretation of factor 4 as plagioclase, a provenance indicator in detrital sedimentary rocks, is indicated by the high loadings of $\log \mathrm{CaO}$ and $\mathrm{Na}_{2} \mathrm{O}$. Both oxides are highly correlated in argillite and siltite, but they are correlated most strongly in sandstones of the Apple Creek and Gunsight Formations of the Salmon River Mountains, where currents probably segregated feldspar sand from clay (fig. 4A). The linking of factor 4 to plagioclase is confirmed by the correlation of volume percent plagioclase, estimated from thin sections, with $\log \mathrm{CaO}$ and
$\mathrm{Na}_{2} \mathrm{O}$ in sandstone (fig. $4 B$ ). Strontium readily substitutes for calcium in plagioclase (Smith and Brown, 1988), and this relationship is evident from the high correlation of log Sr with log $\mathrm{CaO}$ (fig. $4 C$ ). The logarithmic distribution of both elements is consistent with substitution in the same mineral. The correlation of $\mathrm{Na}_{2} \mathrm{O}$ with $\log \mathrm{Sr}$ is simply a consequence of the correlation of $\log \mathrm{CaO}$ with both $\mathrm{Na}_{2} \mathrm{O}$ and $\log \mathrm{Sr}$ (fig. 4D). The moderate loadings of $\log \mathrm{Y}$ and $\log \mathrm{Yb}$ on factor 4 (table 3 ) may also reflect substitution of those elements for calcium in plagioclase. The composition of plagioclase was not investigated in detail; twin extinction angles observed in thin section suggest a composition in the range of andesine and oligoclase.

An R-mode factor analysis of geochemical data for the Lemhi Range yields a model similar to that of the Salmon River Mountains. A four-factor solution was selected after inspection of eigenvalues on a graph (root curve method) and comparison of communalities for various solutions involving factors other than four (Lindsey and others, 2002). The Lemhi Range data set represents the Big Creek and Apple Creek Formations, but not the Gunsight. The data set lacks many of the trace elements determined in the Salmon River Mountains. Interpretation of the Lemhi Range model is essentially the same as that for the Salmon River Mountains, but relationships among some trace elements are not available. Four factors were identified: (1) micas (grain size of original sediment), (2) plagioclase (provenance), (3) chlorite (grain size), and (4) iron-oxide minerals (placer concentration or mineralization) (table 4). A factor for rare earth minerals (provenance or metamorphism), seen in factor analysis of Salmon River data, was not detected. Cerium and neodymium were not analyzed; lanthanum and yttrium, which were analyzed, load on factor 1 , but their low communalities indicate that they may belong to another, unidentified factor or factors. The four-factor solution of Lemhi Range data yields two factors for grain size, a somewhat more complicated interpretation than desired.

Factor 2 (plagioclase) of the Lemhi Range data set is the same as factor 4 in the Salmon River Mountains. A scattergram for $\log \mathrm{CaO}$ versus $\log \mathrm{Na}_{2} \mathrm{O}$ (both $\log \mathrm{CaO}$ and $\log \mathrm{Na}_{2} \mathrm{O}$ have high loadings on factor 2) shows a weak linear correlation of 0.446 (fig. 5). Eleven $\mathrm{Na}_{2} \mathrm{O}$ values that plot at 0.1 percent $(\log -1)$ have widely varying $\mathrm{CaO}$ contents, and many high values for $\log \mathrm{CaO}$ in siltite and sandstone of the Big Creek Formation (fig. 5B) depart widely from the line of best fit, which weakens the correlation. Calcite and dolomite account for high $\mathrm{CaO}$ values in the Big Creek Formation (Tysdal, 2000b; G.A. Desborough, written commun., 2000), and their presence seriously undermines the use of $\mathrm{CaO}$ as an indicator of plagioclase in the Big Creek. Values for the diamictite unit of the Apple Creek Formation, which does not contain carbonate minerals, plot close to the line of best fit (fig. $5 B$ ).

\section{Stratigraphic Variation in Sediment Provenance}

Analysis of variance and tests for differences among means were conducted to test for stratigraphic variation in both the Salmon River Mountains and Lemhi Range data sets (Lindsey and others, 2002). Stratigraphic units for which geochemical 
Table 3. R-mode factor analysis of geochemical data, Apple Creek and Gunsight Formations, Salmon River Mountains.

[Shown are orthogonal axes, four factors (Varimax rotation), calculated from data of Connor (1990). Factor interpretations shown at bottom. Bold type, factor loadings $>[0.50]$ (absolute value); italic type, oxides or elements with communality $<0.50$. Log oxide or element denotes data that were transformed to logarithms before computation of input correlation matrix. (See Lindsey and others, 2002, for further explanation.) $\mathrm{Fe}_{\mathrm{T}} \mathrm{O}_{3}$, total iron as $\mathrm{Fe}_{2} \mathrm{O}_{3}$; $\mathrm{LOI}$, loss on ignition]

\begin{tabular}{|c|c|c|c|c|}
\hline Oxide or element & Factor 1 & Factor 2 & Factor 3 & Factor 4 \\
\hline $\mathrm{SiO}_{2}$ & -.950 & -.086 & -.092 & -.055 \\
\hline $\mathrm{Al}_{2} \mathrm{O}_{3}$ & .896 & .007 & -.028 & .117 \\
\hline $\log \mathrm{Fe}_{\mathrm{T}} \mathrm{O}_{3}$ & .379 & .198 & .426 & -.438 \\
\hline $\log \mathrm{MgO}$ & .727 & .223 & .177 & .040 \\
\hline $\log \mathrm{CaO}$ & .309 & .204 & .183 & .806 \\
\hline $\mathrm{Na}_{z} \mathrm{O}$ & -.268 & .053 & .107 & .785 \\
\hline $\mathrm{K}_{2} \mathrm{O}$ & .703 & -.002 & -.320 & -.415 \\
\hline $\mathrm{TiO}_{2}$ & .866 & .038 & .191 & .182 \\
\hline $\mathrm{P}_{2} \mathrm{O}_{5}$ & .541 & .082 & .235 & .329 \\
\hline LOI & .742 & .037 & .259 & -.057 \\
\hline $\log A s$ & .197 & -.137 & .594 & .110 \\
\hline $\log B$ & .394 & .236 & -.350 & .042 \\
\hline $\log B a$ & .549 & .009 & -.145 & -.223 \\
\hline $\mathrm{Be}$ & .824 & .094 & -.086 & .075 \\
\hline $\log \mathrm{Ce}$ & .016 & .878 & .204 & .149 \\
\hline Log Co & .442 & .149 & .577 & -.073 \\
\hline $\mathrm{Cr}$ & .710 & -.080 & .192 & .179 \\
\hline $\log C u$ & -.137 & .113 & .535 & .079 \\
\hline $\log \mathrm{Ga}$ & .912 & .055 & .007 & -.017 \\
\hline $\mathrm{La}$ & .066 & .913 & .136 & .184 \\
\hline $\log \mathrm{Li}$ & .732 & .358 & .224 & .074 \\
\hline $\log M n$ & .241 & .276 & .659 & .311 \\
\hline $\mathrm{Nd}$ & .123 & .917 & .068 & .176 \\
\hline $\mathrm{Ni}$ & .660 & .171 & .327 & .210 \\
\hline $\log \mathrm{Pb}$ & -.080 & .097 & .688 & .213 \\
\hline $\log S b$ & .181 & .098 & .512 & .117 \\
\hline $\mathrm{Sc}$ & .913 & -.050 & .157 & .090 \\
\hline $\log \mathrm{Sr}$ & .097 & .232 & .141 & .820 \\
\hline $\log T h$ & .721 & .352 & -.022 & .035 \\
\hline $\mathrm{U}$ & .649 & .394 & .288 & .027 \\
\hline V & .863 & -.137 & .199 & .018 \\
\hline $\log Y$ & .262 & .523 & .244 & .537 \\
\hline $\log \mathrm{Yb}$ & .443 & .250 & .253 & .571 \\
\hline $\log \mathrm{Zn}$ & .149 & .170 & .782 & .008 \\
\hline $\log Z r$ & .507 & .301 & .092 & -.116 \\
\hline
\end{tabular}

Factor 1-Micas and chlorite $\left(\mathrm{Al}_{2} \mathrm{O}_{3}, \log \mathrm{MgO}, \mathrm{K}_{2} \mathrm{O}, \mathrm{TiO}_{2}, \mathrm{LOI}, \mathrm{Be}, \log \mathrm{Cr}, \log \mathrm{Ga}, \log \mathrm{Li}, \mathrm{Ni}, \mathrm{Sc}, \log \right.$ Th, $\mathrm{U}$, and $\mathrm{V}$ ) versus $\mathrm{SiO}_{2}$ - grain size. $\mathrm{P}_{2} \mathrm{O}_{5}, \log \mathrm{Ba}$, and $\log \mathrm{Zr}$ have high loadings $(>0.50$ ) but low communalities $(<0.50)$.

Factor 2-Rare earth minerals ( $\log \mathrm{Ce}, \mathrm{La}, \mathrm{Nd}$, and $\log \mathrm{Y})$ - provenance or metamorphism.

Factor 3-Base metals in $\mathrm{MnO}(\log \mathrm{Co}, \log \mathrm{Mn}, \log \mathrm{Pb}$, and $\log \mathrm{Zn})$ - mineralization. $\log \mathrm{As}, \log$ $\mathrm{Cu}$, and log Sb have high loadings $(>0.50)$ but low communalities $(<0.50)$.

Factor 4-Plagioclase (log $\mathrm{CaO}, \mathrm{Na}_{2} \mathrm{O}, \log \mathrm{Sr}, \log \mathrm{Y}$, and $\left.\log \mathrm{Yb}\right)$ - provenance.

data are available in the Salmon River Mountains differ from those in the Lemhi Range. The Big Creek Formation and the diamictite unit of the Apple Creek Formation are not exposed in most of the Salmon River Mountains, and the banded siltite unit of the Apple Creek Formation is not exposed in the Lemhi Range. In the Salmon River Mountains, no differences in plagioclase content (as represented by factor $4-\log \mathrm{CaO}, \mathrm{Na}_{2} \mathrm{O}$, and $\log \mathrm{Sr}$ ) among the various units of the Apple Creek
Formation and Gunsight Formation were found. In the Lemhi Range, significant differences in plagioclase content (as represented by factor 2 and $\log \mathrm{Na}_{2} \mathrm{O}$ ) were found among siltites in the Big Creek and Apple Creek Formations (table 5; fig. 6). No significant stratigraphic differences were found for $\log \mathrm{CaO}$ at the 0.05 level. In the Big Creek Formation, $\mathrm{CaO}$ content in part reflects calcite and dolomite (Tysdal, 2000b; G.A. Desborough, written commun., 2000), so $\mathrm{CaO}$ cannot be used to measure 

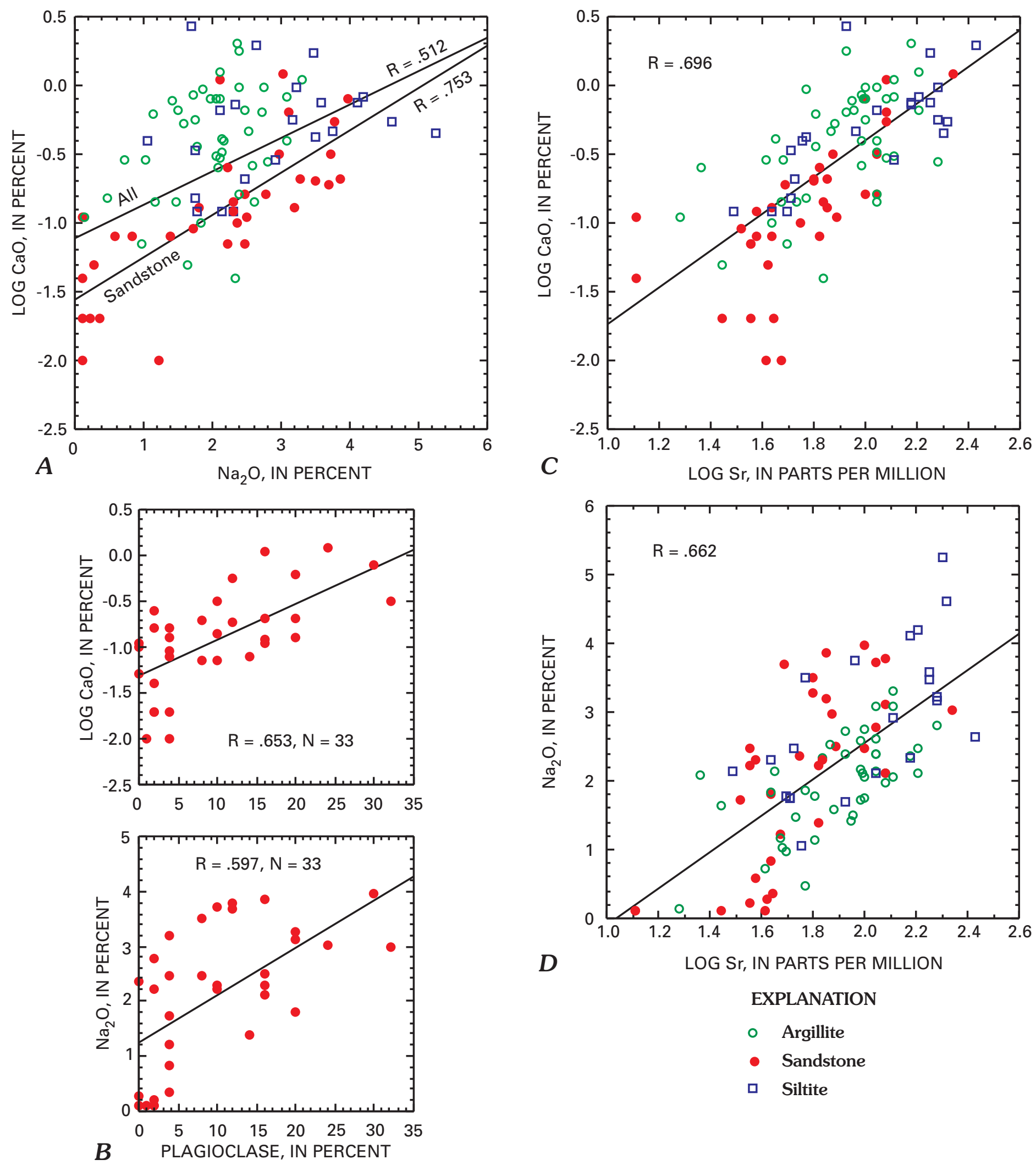

\section{EXPLANATION}

- Argillite

- Sandstone

․ Siltite

Figure 4. Major oxides and elements, showing effect of plagioclase content on geochemical covariation in rocks of the Apple Creek and Gunsight Formations, Salmon River Mountains (calculated from data of Connor, 1990). $A$, log $\mathrm{CaO}$ versus $\mathrm{Na}_{2} \mathrm{O} ; B_{,} \log \mathrm{CaO}$ and $\mathrm{Na}_{2} \mathrm{O}$ versus plagioclase in sandstone; $C_{r} \log \mathrm{CaO}$ versus $\log \mathrm{Sr} ; D, \mathrm{Na}_{2} \mathrm{O}$ versus $\log \mathrm{Sr}$. $\mathrm{R}$, correlation coefficient; lines are least-squares fit. All chemical elements in weight percent or parts per million; plagioclase in volume percent, estimated by J.J. Connor. 
Table 4. R-mode factor analysis of geochemical data, Big Creek and Apple Creek Formations, Lemhi Range.

[Shown are orthogonal axes, four factors (Varimax rotation), calculated from data on samples collected by R.G. Tysdal. Factor interpretations shown at bottom. Bold type, factor loadings $>[0.50]$ (absolute value); italic type, oxides or elements with communality $<0.50$. Log oxide or element denotes data that were transformed to logarithms before computation of input correlation matrix. (See Lindsey and others, 2002, for further explanation.) $\mathrm{Fe}_{\mathrm{T}} \mathrm{O}_{3}$, total iron as $\mathrm{Fe}_{2} \mathrm{O}_{3}$; LOI, loss on ignition]

\begin{tabular}{|c|c|c|c|c|}
\hline Oxide or element & Factor 1 & Factor 2 & Factor 3 & Factor 4 \\
\hline $\mathrm{SiO}_{2}$ & -.566 & -.044 & -.335 & -.644 \\
\hline $\mathrm{Al}_{2} \mathrm{O}_{3}$ & .584 & .161 & .378 & .417 \\
\hline $\log \mathrm{Fe}_{\mathrm{T}} \mathrm{O}_{3}$ & .329 & -.157 & .155 & 698 \\
\hline $\log \mathrm{MgO}$ & .102 & -.120 & .839 & .057 \\
\hline $\log \mathrm{CaO}$ & .163 & .662 & .115 & -.443 \\
\hline $\log \mathrm{Na}_{2} \mathrm{O}$ & -.034 & .834 & .017 & .095 \\
\hline $\mathrm{K}_{2} \mathrm{O}$ & .583 & -.306 & .217 & .425 \\
\hline $\log \mathrm{TiO}_{2}$ & .703 & .302 & .340 & .324 \\
\hline $\log \mathrm{P}_{2} \mathrm{O}_{5}$ & .542 & .475 & .243 & .063 \\
\hline $\log \mathrm{MnO}$ & .088 & .405 & -.137 & -.014 \\
\hline Log LOI & .416 & -.231 & .553 & -.061 \\
\hline $\log B$ & .776 & -.242 & .141 & -.072 \\
\hline $\log \mathrm{Ba}$ & .433 & -.316 & -.128 & .592 \\
\hline $\log B e$ & .515 & -.408 & .144 & .181 \\
\hline Log Co & -.125 & .041 & .477 & .503 \\
\hline $\log \mathrm{Cr}$ & .670 & .294 & .293 & -.063 \\
\hline $\log \mathrm{Cu}$ & -.077 & -.027 & .110 & 679 \\
\hline $\log \mathrm{Ga}$ & .708 & .012 & .109 & .387 \\
\hline $\log L a$ & .511 & .078 & -.029 & .081 \\
\hline $\log \mathrm{Ni}$ & .233 & .138 & .777 & .167 \\
\hline $\log P b$ & .170 & .194 & -.296 & .448 \\
\hline Log Sc & .784 & .119 & .059 & .354 \\
\hline $\log \mathrm{V}$ & .785 & .159 & .120 & .234 \\
\hline $\log Y$ & .593 & .032 & -.062 & .026 \\
\hline $\log \mathrm{Zr}$ & .736 & .001 & .088 & -.138 \\
\hline
\end{tabular}

Factor 1-Micas $\left(\mathrm{Al}_{2} \mathrm{O}_{3}, \mathrm{~K}_{2} \mathrm{O}, \log \mathrm{TiO}_{2}, \log \mathrm{P}_{2} \mathrm{O}_{5}, \log \mathrm{B}, \log \mathrm{Cr}, \log \mathrm{Ga}, \log \mathrm{Sc}, \log \mathrm{V}\right.$, and $\log \mathrm{Zr}$ ) versus $\mathrm{SiO}_{2}$ - grain size. $\mathrm{Log} \mathrm{Be}, \log \mathrm{La}$, and log $\mathrm{Y}$ have high loadings $(>0.50)$ but low communalities $(<0.50)$. Factor 2-Plagioclase $\left(\log \mathrm{CaO}\right.$ and $\left.\log \mathrm{Na}_{2} \mathrm{O}\right)$ - provenance.

Factor 3-Chlorite-(Log $\mathrm{MgO}, \log \mathrm{LOI}$, and $\log \mathrm{Ni}$ - grain size.

Factor 4-Iron oxide minerals $\left(\log \mathrm{Fe}_{\mathrm{T}} \mathrm{O}_{3}, \log \mathrm{Ba}, \log \mathrm{Co}\right.$, and $\log \mathrm{Cu}$ ) versus $\mathrm{SiO}_{2}$ - Placer concentration or mineralization. $\log \mathrm{Pb}$ has loading of 0.448 but low communality $(<0.50)$.

stratigraphic variation in plagioclase content of the Big Creek. Probably, $\mathrm{Na}_{2} \mathrm{O}$ values are the best indicator of plagioclase.

In the Lemhi Range, the distribution of plagioclase differs greatly in the diamictite and coarse siltite units of the Apple Creek Formation. The diamictite unit exhibits a wide range of $\mathrm{Na}_{2} \mathrm{O}$ values, whereas the coarse siltite unit, deposited by turbidity currents, exhibits a narrow range of $\mathrm{Na}_{2} \mathrm{O}$ values (fig. $5 B$ ). The range in $\mathrm{CaO}$ values in the diamictite unit is also greater than in the coarse siltite unit, but the contrast is less striking. When only siltites are compared (fig. 6), the range in $\mathrm{Na}_{2} \mathrm{O}$ values in the diamictite unit is also greater than in the coarse siltite unit. The wide range in plagioclase content of the diamictite may reflect incomplete mixing of parent material of varying provenance, consistent with redeposition by locally derived debris flows. Siltite beds in the diamictite unit could have formed by reworking of diamictite, or they could be downstream equivalents of diamictite. In contrast to the diamictite unit, the uniform plagioclase content as indicated by the $\mathrm{Na}_{2} \mathrm{O}$ content of the coarse siltite unit probably reflects thorough mixing of sediment during redeposition by turbidity flows. 

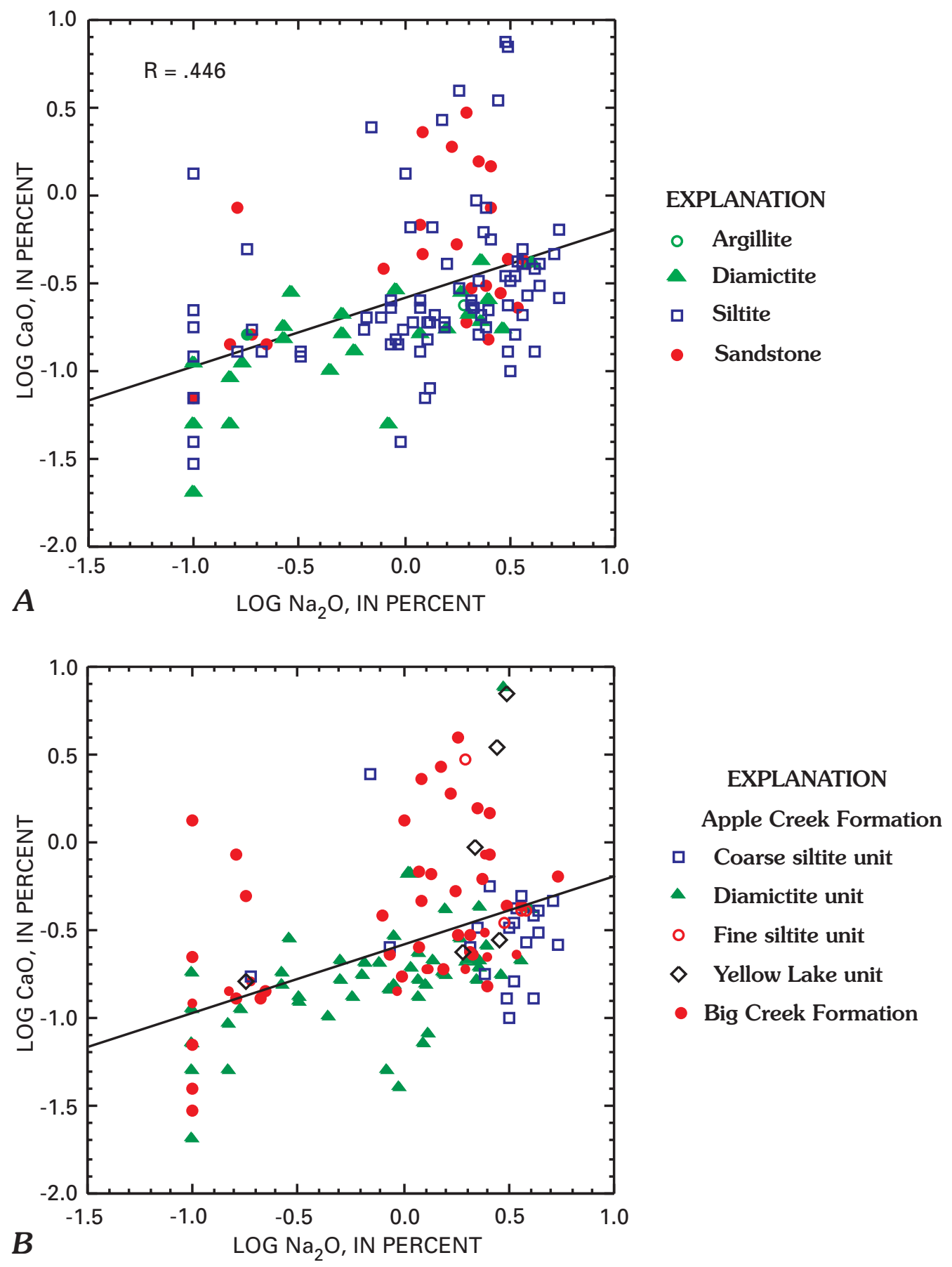

Figure 5. Log $\mathrm{CaO}$ versus $\log \mathrm{Na}_{2} \mathrm{O}$, showing effect of plagioclase and calcite content on major-oxide covariation in rocks of the Big Creek and Apple Creek Formations, Lemhi Range. A, Samples classified by rock type (grain size); $B$, samples classified by stratigraphic unit. $\mathrm{R}$, correlation coefficient; line is least-squares fit.

The plagioclase content of the Big Creek Formation, as expressed by $\mathrm{Na}_{2} \mathrm{O}$ content, is also variable (fig. $5 B$ ). The range in $\mathrm{Na}_{2} \mathrm{O}$ content of siltite in the Big Creek is comparable to that of siltite in the diamictite unit of the Apple Creek Formation (fig. 6). The wide range in plagioclase content of the Big Creek is consistent with reworking, and variable degrees of destruction of plagioclase, in a nearshore environment. Most of the Big Creek represented in the Lemhi Range sample set was deposited in intertidal and shallow subtidal environments (Tysdal, 2000b).

The stratigraphic variation in plagioclase in the Lemhi Range, as best expressed by variation in $\log \mathrm{Na}_{2} \mathrm{O}$ in siltites among stratigraphic units (table 5), is interpreted as variation in 
Table 5. Analysis of variance and Fisher's PLSD test for differences among mean values for factor 2 scores, $\log \mathrm{CaO}$, and $\log \mathrm{Na}_{2} \mathrm{O}$ in siltite samples from the Big Creek and Apple Creek Formations, Lemhi Range.

[Yac, coarse siltite unit of Apple Creek Formation; Yad, diamictite unit of Apple Creek Formation; Yb, Big Creek Formation. Number of samples for factor 2 scores, 59; for $\log \mathrm{CaO}$ and $\log \mathrm{Na}_{2} \mathrm{O}, 66$. F-value, mean square of effect (Formation) divided by residual mean square; P-value, probability of no difference among formations; S, significant at $<0.05$ level; blank, not applicable]

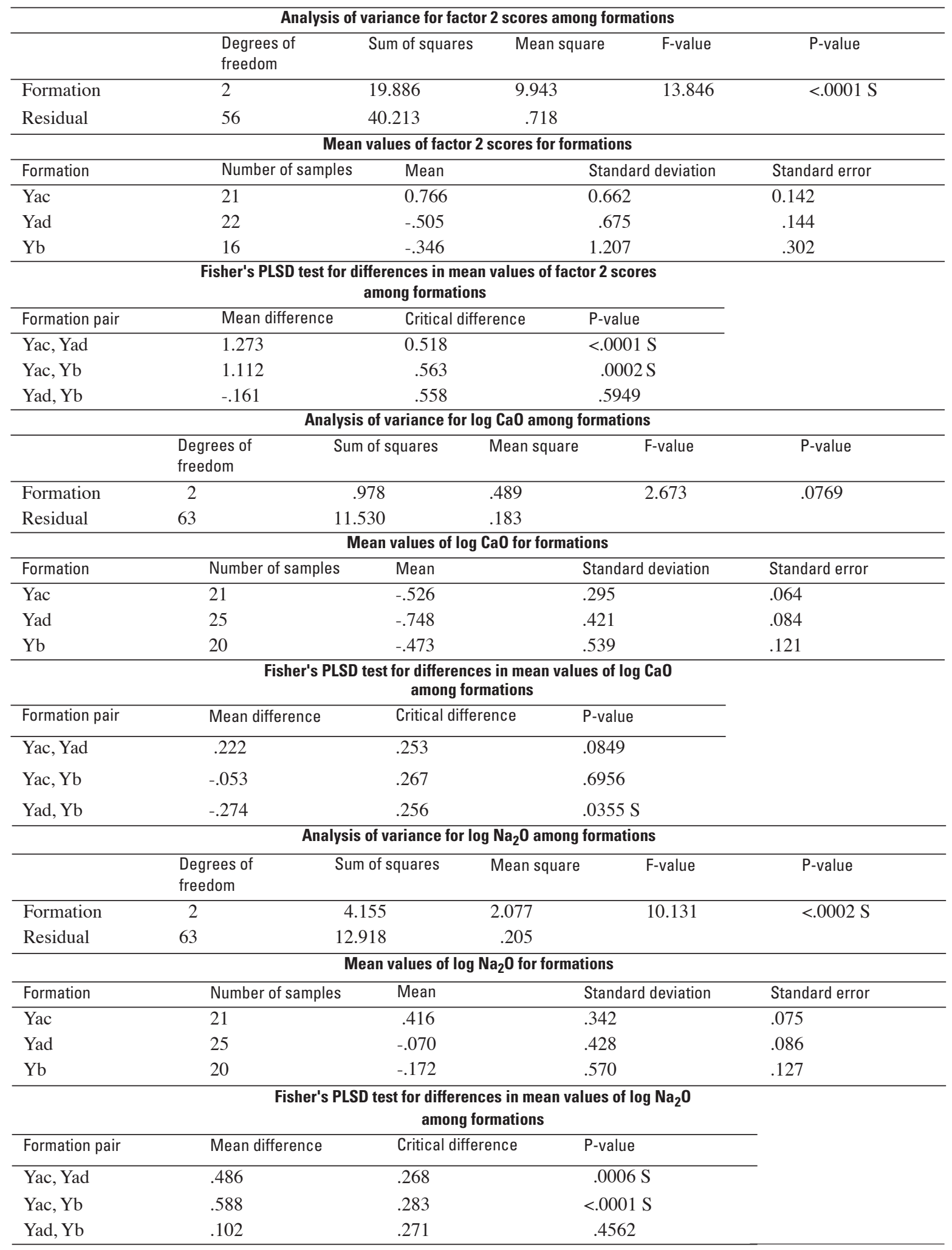




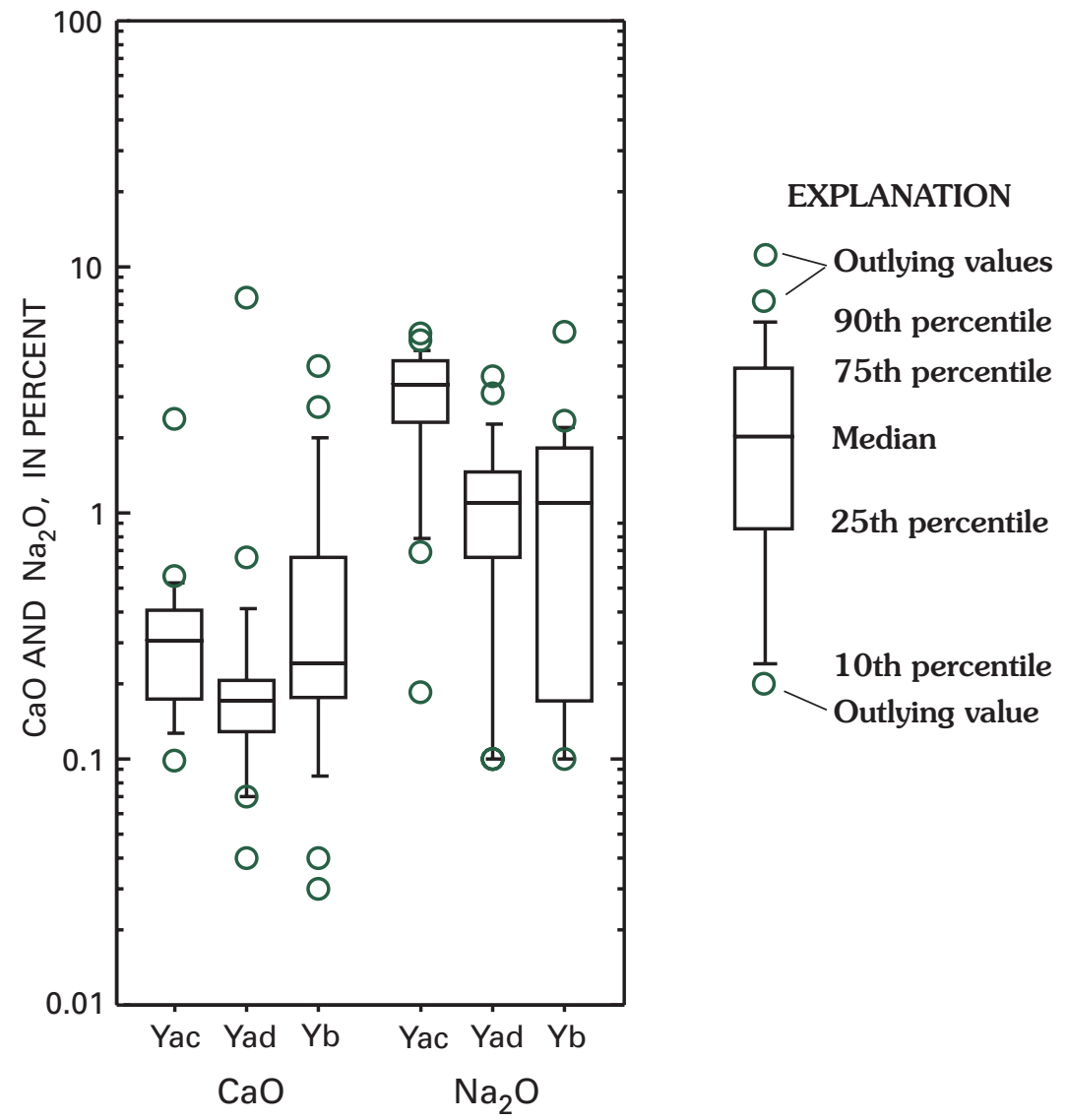

Figure 6. Box plots showing $\mathrm{CaO}$ and $\mathrm{Na}_{2} \mathrm{O}$ content of siltite in the Big Creek and Apple Creek Formations, Lemhi Range. Major-oxide values are plotted on a logarithmic scale. Yac, coarse siltite unit of Apple Creek Formation; Yad, diamictite unit of Apple Creek Formation; Yb, Big Creek Formation.

provenance during deposition of the Big Creek and Apple Creek Formations. Relative to quartz and alkali feldspar, plagioclase is less stable during weathering. Most likely, the proportion of plagioclase that was available for deposition varied with the degree of weathering during erosion of the source area and storage in alluvial and marine environments, prior to final deposition.

\section{Conclusions}

The Big Creek, Apple Creek, and Gunsight Formations of the Lemhi Group were derived from a terrane having the majoroxide composition of the Archean quartzo-feldspathic gneiss (also known as the "Dillon Granite Gneiss") of southwestern Montana. Whether the Archean gneiss of southwestern Montana was the source, as suggested by paleocurrents and conglomerate in the Gunsight Formation (R.G.Tysdal, D.A. Lindsey, and K.I. Lund, unpub. data, 2002), or whether some other gneiss terrane also contributed detritus to the Lemhi Group, cannot be determined from major-oxide data alone. In any case, derivation from a gneiss terrane implies an intracratonic source.
Sediments of the Big Creek, Apple Creek, and Gunsight Formations were rich in plagioclase, which was derived from gneiss. Plagioclase content is reflected in values for $\mathrm{CaO}$ (except in the Big Creek Formation, which contains calcite and dolomite) and $\mathrm{Na}_{2} \mathrm{O}$, which can be used as proxies for the amount of plagioclase. To varying degrees, plagioclase was converted to clays (and $\mathrm{CaO}$ and $\mathrm{Na}_{2} \mathrm{O}$ were depleted) during weathering of the source area and transit to the depositional basin. In the Lemhi Range, plagioclase content of siltite varies in the Big Creek and Apple Creek Formations, indicating varying source areas or variable rates of weathering, erosion, and sediment transport over time.

\section{References Cited}

Anderson, D.L., Mock, D.W., and Childs, J.F., 1990, Petrogenesis and timing of talc formation in the Ruby Range, southwestern Montana: Economic Geology, v. 85, no. 3, p. 585-600.

Baedecker, P.A., Grossman, J.N., and Buttleman, K.P., 1998, National Geochemical Data Base; PLUTO Geochemical data base for the United States: U.S. Geological Survey Digital Data Series DDS-47 (CD-ROM). 
Connor, J.J., 1990, Geochemical stratigraphy of the Yellowjacket Formation (Middle Proterozoic) in the area of the Idaho Cobalt Belt, Lemhi County, Idaho, with Analytical contributions from A.J. Bartel, E. Brandt, P.H. Briggs, S. Danahey, D. Fey, D.B. Hatfield, M. Malcolm, V. Merritt, G. Riddle, S. Roof, K. Stewart, J. Storey, J.E. Taggart, Jr., and R.B. Vaughn: U.S. Geological Survey Open-File Report 90-0234 (Part A, Discussion, 29 p.; Part B, Geochemical data files, 1 diskette).

Connor, J.J., 1991, Some geochemical features of the Blackbird and Jackass zones of the Yellowjacket Formation (Middle Proterozoic) in east-central Idaho, with Analytical contributions from A.J. Bartel, P.H. Briggs, R.R. Carlson, J.G. Crock, B.H. Roushey, C.S.E. Papp, D.F. Siems, J.E. Taggart, Jr., and E.P. Welsch: U.S. Geological Survey Open-File Report 91-0259 (Part A, Discussion, 25 p.; Part B, Geochemical data files, 1 diskette).

Connor, J.J., and Evans, K.V., 1986, Geologic map of the Leesburg quadrangle, Lemhi County, Idaho: U.S. Geological Survey Miscellaneous Field Studies Map MF-1880, scale 1:62,500.

Cooley, W.W., and Lohnes, P.R., 1962, Multivariate procedures for the behavioral sciences: New York, John Wiley, 211 p.

Cressman, E.R., 1989, Reconnaissance stratigraphy of the Prichard Formation (Middle Proterozoic) and the early development of the Belt basin, Washington, Idaho, and Montana: U.S. Geological Survey Professional Paper 1490, 80 p.

Doughty, P.T., and Chamberlain, K.R., 1996, Salmon River arch revisitedNew evidence for $1370 \mathrm{Ma}$ rifting near the end of deposition in the Middle Proterozoic Belt basin: Canadian Journal of Earth Sciences, v. 33, no. 7, p. 1037-1052.

Evans, K.V., and Connor, J.J., 1993, Geologic map of the Blackbird Mountain 15-minute quadrangle, Lemhi County, Idaho: U.S. Geological Survey Miscellaneous Field Studies Map MF-2234, scale 1:62,500.

Garihan, J.M., and Williams, K., 1976, Petrography, modal analyses, and origin of Dillon quartzo-feldspathic and pre-Cherry Creek gneisses, Ruby Range, southwestern Montana: Northwest Geology, v. 5, p. 42-49.

Golightly, D.W., Dorrzapf, A.F., Jr., Mays, R.E., Fries, T.L., and Conklin, N.M., 1987, Analysis of geologic materials by direct-current arc emission spectrography and spectrometry, in Baedecker, P.A., ed., Methods of geochemical analysis: U.S. Geological Survey Bulletin 1770, p. A1-A13.

Herron, M.M., 1988, Geochemical classification of terrigenous sands and shales from core or log data: Journal of Sedimentary Petrology, v. 58 , no. 5, p. 820-829.

Jackson, D.A., 1993, Stopping rules in principal components analysis; a comparison of heuristical and statistical approaches: Ecology, v. 74, no. 8, p. 2204-2214.

James, H.L., 1990, Precambrian geology and bedded iron deposits of the southwestern Ruby Range, Montana: U.S. Geological Survey Professional Paper 1495, $39 \mathrm{p}$.

Krumbein, W.C., and Graybill, F.A., 1965, An introduction to statistical models in geology: New York, McGraw-Hill, $475 \mathrm{p}$.

Le Maitre, R.W., 1976, The chemical variability of some common igneous rocks: Journal of Petrology, v. 17, no. 4, p. 589-637.

Lichte, F.E., Golightly, D.W., and Lamothe, P.J., 1987, Inductively coupled plasma-atomic emission spectrometry, in Baedecker, P.A., ed., Methods of geochemical analysis: U.S. Geological Survey Bulletin 1770, p. B1-B10.

Lindsey, D.A., 1999, An evaluation of alternative chemical classifications of sandstones: U.S. Geological Survey Open-File Report 99-346, 23 p.
Lindsey, D.A., Tysdal, R.G., and Taggart, J.E., Jr., 2002, Statistical tables and charts showing geochemical variation in the Middle Proterozoic Big Creek, Apple Creek, and Gunsight Formations, Salmon River Mountains and Lemhi Range, Idaho: U.S. Geological Survey OpenFile Report 02-310, $69 \mathrm{p}$.

Lopez, D.A., 1981, Stratigraphy of the Yellowjacket Formation of eastcentral Idaho: U.S. Geological Survey Open-File Report 81-1088, 203 p.

McBean, A.J., II, 1983, The Proterozoic Gunsight Formation, Idaho-Montana; stratigraphy, sedimentology and paleotectonic setting: University Park, Pa., The Pennsylvania State University M.S. thesis, 235 p.

McKown, D.M., and Millard, H.T., Jr., 1987, Determination of uranium and thorium by delayed neutron counting, in Baedecker, P.A., ed., Methods of geochemical analysis: U.S. Geological Survey Bulletin 1770, p. I1-I12.

M'Gonigle, J.W., 1993, Geologic map of the Medicine Lodge Peak Quadrangle, Beaverhead County, Montana: U.S. Geological Survey Geologic Quadrangle Map G0-1724, scale 1:24,000.

Pettijohn, F.J., Potter, P.E., and Siever, R., 1972, Sand and sandstone: New York, Springer, $618 \mathrm{p}$.

Ryan, P.C., and Buckley, S., 1999, Sedimentation, stratabound Cu-Ag mineralization, and syndepositional tectonics in the Revett Formation, Flathead Indian Reservation, western Montana, in Berg, R.B., ed., Belt Symposium III: Montana Bureau of Mines Special Publication 112, p. 278-289.

Ruppel, E.T., 1975, Precambrian Y sedimentary rocks in east-central Idaho: U. S. Geological Survey Professional Paper 889-A, 23 p.

Ruppel, E.T., and Lopez, D.A., 1988, Regional geology and mineral deposits in and near the central part of the Lemhi Range, Lemhi County, Idaho: U.S. Geological Survey Professional Paper 1480, 122 p.

SAS Institute Inc., 1998, Statview reference, Second Edition: Cary, N.C., $528 \mathrm{p}$.

Smith, J.V., and Brown, W.L., 1988, Feldspar minerals, Second EditionVolume 1, Crystal structures; physical, chemical and microtextural properties: New York, Springer, 828 p.

Sobel, L.S., 1982, Sedimentology of the Blackbird mining district, Lemhi County, Idaho: Cincinnati, Ohio, University of Cincinnati M.S. thesis, $235 \mathrm{p}$.

Taggart, J.E., Jr., Lindsay, J.R., Scott, B.A., Vivit, D.V., Bartel, A.J., and Stewart, K.C., 1987, Analysis of geologic materials by wavelengthdispersive X-ray fluorescence spectrometry, in Baedecker, P.A., ed., Methods of geochemical analysis: U.S. Geological Survey Bulletin 1770, p. E1-E19.

Tietbohl, D., 1986, Middle Proterozoic diamictite beds in the Lemhi Range, east-central Idaho, in Roberts, S.M., ed., Belt Supergroup; a guide to Proterozoic rocks of western Montana and adjacent areas: Montana Bureau of Mines Special Publication 94, p. 197-207.

Tysdal, R.G., 1996a, Geologic map of the Lem Peak quadrangle, Lemhi County, Idaho: U.S. Geological Survey Geologic Quadrangle Map GQ-1777, scale 1:24,000.

Tysdal, R.G., 1996b, Geologic map of adjacent areas in the Hayden Creek and Mogg Mountain Quadrangles, Lemhi County, Idaho: U.S. Geological Survey Geologic Quadrangle Map GQ-2563, scale 1:24,000.

Tysdal, R.G., 2000a, Revision of Middle Proterozoic Yellowjacket Formation, central Idaho: U.S. Geological Survey Professional Paper 1601A, $14 \mathrm{p}$. 
Tysdal, R.G., 2000b, Stratigraphy and depositional environments of Middle Proterozoic rocks in northern part of Lemhi Range, Lemhi County, Idaho: U.S. Geological Survey Professional Paper 1600, 40 p.

Tysdal, R.G., Evans, K.V., and Lund, K.I., 2000, Geologic map of the Blackbird Mountain quadrangle, Lemhi County, Idaho: U.S. Geological Survey Miscellaneous Investigations Series Map I-2628, scale $1: 24,000$.

Tysdal, R.G., and Moye, Falma, 1996, Geologic map of the Allison Creek quadrangle, Lemhi County, Idaho: U.S. Geological Survey Geologic Quadrangle Map G0-1778, scale 1:24,000.

Van de Kamp, P.C., and Leake, B.E., 1994, Petrology, geochemistry, provenance, and alteration of Pennsylvanian-Permian arkose, Colorado and Utah: Geological Society of America Bulletin, v. 105, no. 12, p. 1571-1582.

Wilson, M.L., 1981, Origin of Archean lithologies in the southern Tobacco Root and northern Ruby Ranges of southwestern Montana, in Tucker, T.E., ed., 1981 Field Conference \& Symposium Guidebook to Southwest Montana: Billings, Mont., Montana Geological Society, p. 37-43.

Winston, D., Link, P.K., and Hathaway, N., 1999, The Yellowjacket is not the Prichard and other heresies-Belt Supergroup correlations, structure and paleogeography, east-central Idaho, in Hughes, S.S., and Thackray, G.D., eds., Guidebook to the geology of Eastern Idaho: Pocatello, Idaho, Idaho Museum of Natural History, p. 3-20. 